EDUARDO RUIZ MELCHERT

\title{
ANÁLISE DO DESENVOLVIMENTO DE COMPETÊNCIAS OPERACIONAIS ALINHADAS À POLÍTICA MAKE-TO-ORDER EM UMA EMPRESA DE MANUFATURA CONTRATADA
}

Dissertação apresentada à Escola Politécnica da Universidade de São Paulo para obtenção do Título de Mestre em Engenharia.

São Paulo

2008 


\section{ANÁLISE DO DESENVOLVIMENTO DE COMPETÊNCIAS} OPERACIONAIS ALINHADAS À POLÍTICA MAKE-TO-ORDER EM UMA EMPRESA DE MANUFATURA CONTRATADA

Dissertação apresentada à Escola Politécnica da Universidade de São Paulo para obtenção do Título de Mestre em Engenharia.

Área de Concentração:

Engenharia de Produção

Orientador:

Prof. Dr. Paulino Graciano Francischini

São Paulo 
Este exemplar foi revisado e alterado em relação à versão original, sob responsabilidade única do autor e com a anuência de seu orientador.

São Paulo, 19 de maio de 2008.

Eduardo Ruiz Melchert

Paulino Graciano Francischini

FICHA CATALOGRÁFICA

Melchert, Eduardo Ruiz

Análise do desenvolvimento de competências operacionais alinhadas à política make-to-order em uma empresa de manufatura contratada / E.R. Melchert. -- São Paulo, 2008.

$114 \mathrm{p}$.

Dissertação (Mestrado) - Escola Politécnica da Universidade de São Paulo. Departamento de Engenharia de Produção.

1. Manufatura enxuta 2. Terceirização 3. Produção intermitente 4. Competência 5. Planejamento da produção I. Universidade de São Paulo. Escola Politécnica. Departamento de Engenharia de Produção II. t. 
A meus pais e avós, pelo carinho, amor e educação que muito contribuíram na minha formação. 


\section{AGRADECIMENTOS}

À Universidade de São Paulo, ao Departamento de Engenharia de Produção e à Coordenação de Aperfeiçoamento de Pessoal de Nível Superior - CAPES - pelo apoio institucional, acadêmico e financeiro na realização desta pesquisa.

Ao orientador Prof. Dr. Paulino Graciano Francischini pela dedicação, seriedade e competência, dando apoio e incentivo que foram fundamentais na elaboração dessa dissertação.

Aos Profs. Drs. Dario Ikuo Miyake e Jorge Luiz de Biazzi, cujas críticas e comentários tecidos na fase de qualificação foram tão importantes no direcionamento deste trabalho.

À direção da JohnsonDiversey, em especial ao amigo Eclair Domingues, pelo suporte e compreensão durante a realização do meu curso.

A toda a minha família pela compreensão da minha ausência e, em especial, ao meu irmão Ricardo pelo incentivo em ingressar no programa de mestrado.

A minha esposa pelas inúmeras trocas de impressões, comentários ao trabalho, formatação e execução das figuras. Acima de tudo, pelo inestimável apoio familiar, preenchendo as diversas falhas que tive por força das circunstâncias, e pela paciência revelada ao longo deste período.

A minhas filhas, razão da minha motivação, que com seu amor e ternura tantas vezes trouxeram alegria após dias extenuantes de trabalho.

A todos os que direta ou indiretamente contribuíram para a realização desta pesquisa. 
"Todo homem, por natureza, quer saber." Aristóteles 


\section{RESUMO}

Empresas de manufatura contratada terão sucesso se conseguirem definir sua estratégia por meio do desenvolvimento de competências operacionais alinhadas aos requisitos do mercado, direcionando decisões e ações que as impulsionem a obterem um melhor desempenho. As incertezas, tanto de produtos como de volumes que serão demandados, envolvidas no relacionamento com as empresas-cliente reduzem a oportunidade de um planejamento antecipado da produção, requerendo, então, uma política de atendimento da demanda do tipo make-to-order (MTO). O grande desafio enfrentado pelas empresas que operam no ambiente MTO é atender à demanda do cliente de forma rápida e confiável, ou seja, respeitando-se os prazos e as quantidades requeridos. O objetivo geral deste trabalho foi analisar como práticas do sistema Lean Manufacturing (LM) poderiam ser efetivamente implementadas em conjunto a um sistema de planejamento e controle da produção (PCP) apropriado, visando ao desenvolvimento de competências operacionais alinhadas à política MTO. Os objetivos específicos do estudo concentraram-se em identificar na literatura as principais competências operacionais requeridas no ambiente MTO, discutir o processo de implementação de práticas do sistema LM e comparar, conceitualmente, sistemas de PCP. A empresa de manufatura contratada escolhida para este estudo representava um caso puro da utilização da política MTO, dada a natureza de seu relacionamento com os clientes. A aplicação da metodologia pesquisa-ação permitiu que o estudo fosse conduzido de forma participativa e com uma abordagem de solução de problemas, além de fornecer um roteiro de referência, relacionando as etapas da pesquisa aos conceitos abordados na literatura. Como resultado, verificou-se que a adoção de práticas do sistema LM auxilia de forma significativa no desenvolvimento de competências operacionais em empresas que operam em ambientes MTO. No entanto, é necessário que estas práticas estejam associadas a um sistema de PCP apropriado - Workload Control (WLC) - para que se obtenham os resultados esperados.

Palavras-chave: manufatura contratada, make-to-order, competências, Lean Manufacturing, planejamento e controle da produção. 


\begin{abstract}
Contract manufacturing companies will succeed if they can define their strategy through the development of operational competencies aligned to market requirements, directing decisions and actions that lead them to have a better performance. The relationship with the hiring firm involves multiple products and demand uncertainty, reducing the opportunities for advanced planning, requiring a make-to-order (MTO) demand management policy. The main challenge faced by companies operating in an MTO environment is to achieve high delivery reliability in terms of order quantities and delivery schedules. The general objective of this study was to analyze how Lean Manufacturing (LM) practices could be effectively implemented together with an appropriate production planning and control system (PPC), aiming to develop operational competences aligned to the MTO policy. The specific objectives of this study include identifying in the literature the main operational competencies required to operate on a MTO basis, discussing the LM implementation process and comparing conceptually PPC systems. The contract manufacturing company chosen for this study operated according to a MTO policy due to the nature of its relationship with the customers. The application of the action research methodology allowed conducting the study in a participative manner, using a problem solving approach and providing a reference guide relating the action research steps to concepts discussed in the literature review. As a result, it was found that the adoption of LM practices contributes substantially to the development of operational competences in companies operating in an MTO environment. However, it is necessary that these practices are associated with an appropriated PPC - Workload Control - to obtain the expected results.
\end{abstract}

Keywords: contract manufacturer, make-to-order, skills, Lean Manufacturing, planning and production control. 


\section{SUMÁRIO}

1 INTRODUÇÃO

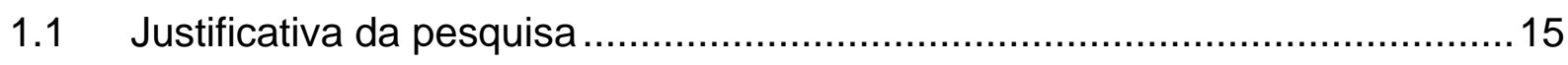

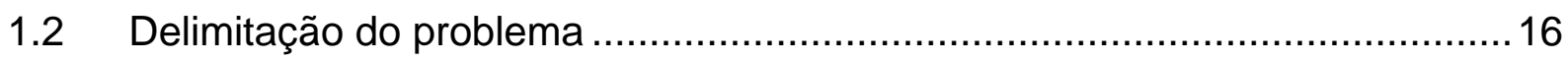

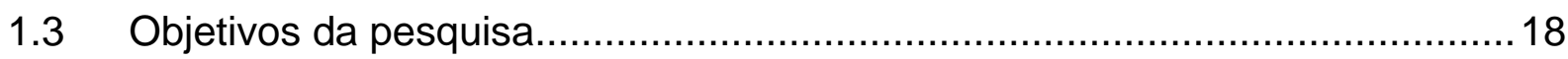

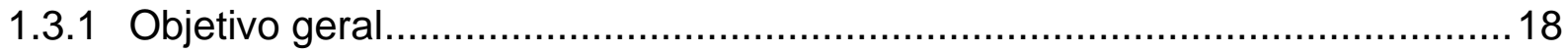

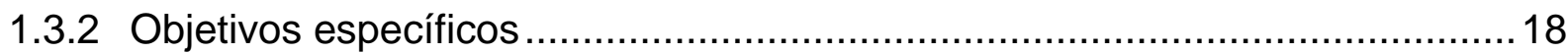

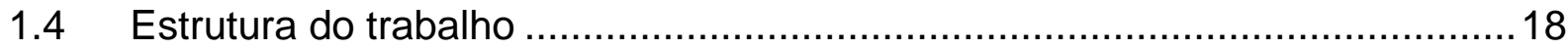

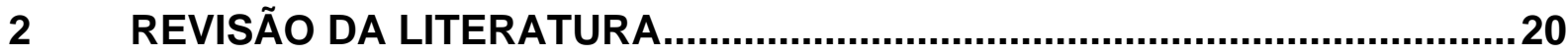

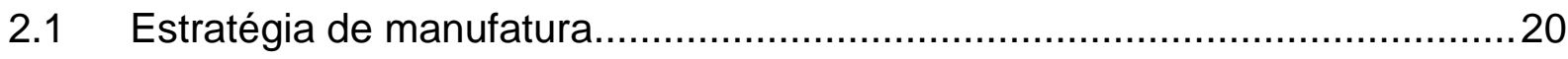

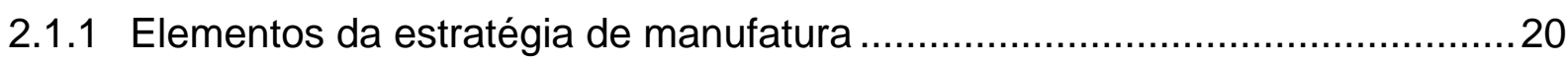

2.1.2 Processo de formulação e implementação da estratégia de manufatura .......22

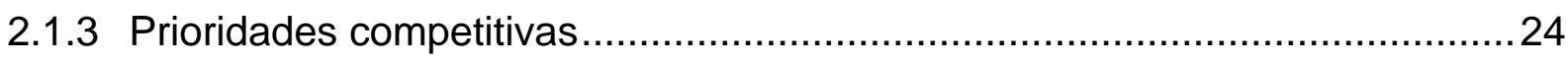

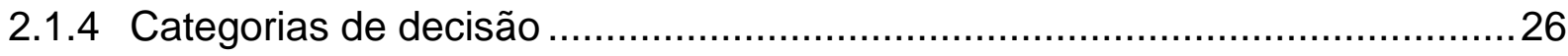

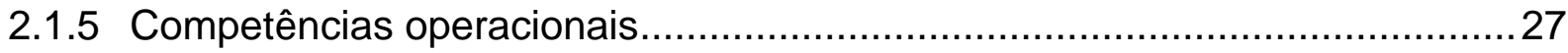

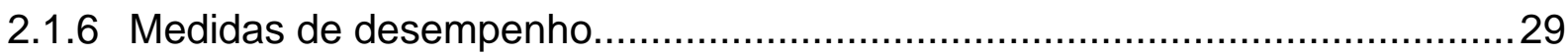

2.2 Decisões estratégicas em manufaturas contratadas .....................................31

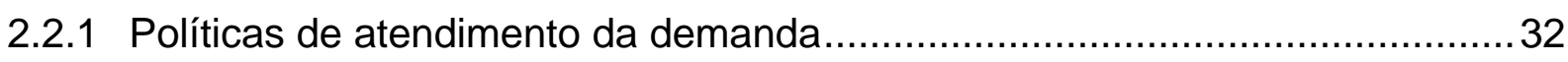

2.2.2 Competências operacionais relacionadas às políticas de atendimento da

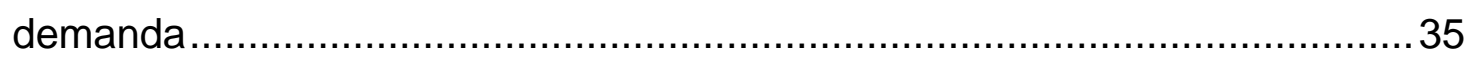

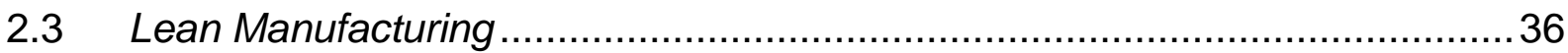

2.3.1 Processo de implementação do sistema LM ............................................. 43

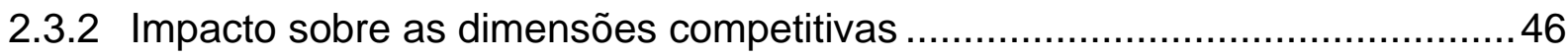

2.3.3 Complexidade e investimento envolvidos no processo de implementação .... 48

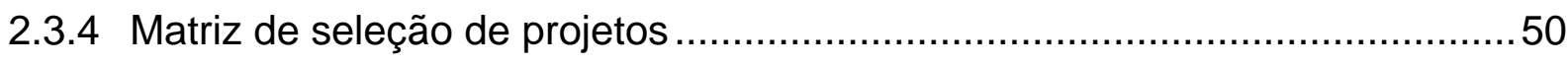

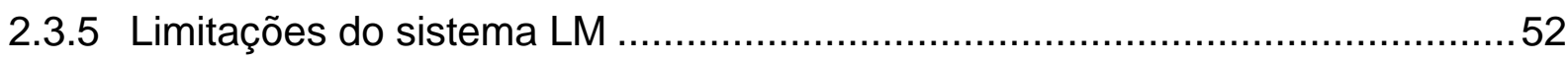

2.4 Sistemas de planejamento e controle da produção (PCP) ……………….....53

2.4.1 Requisitos do sistema de PCP voltados à política MTO ...............................54

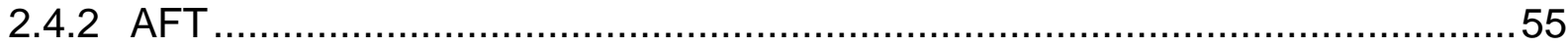

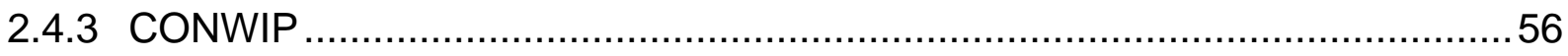

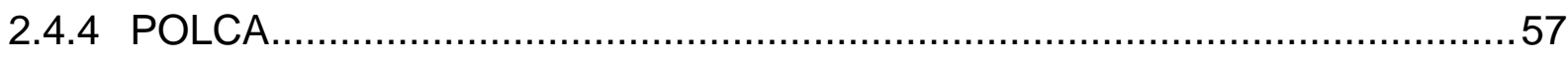




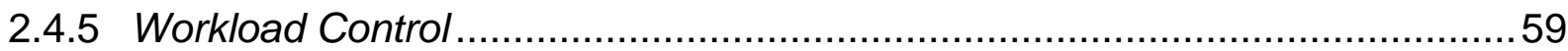

2.4.6 Análise da adequação dos sistemas de PCP à política MTO ......................62

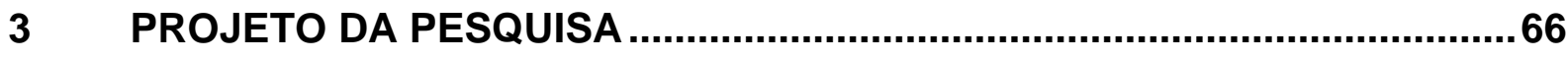

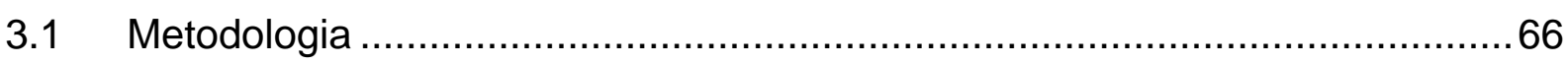

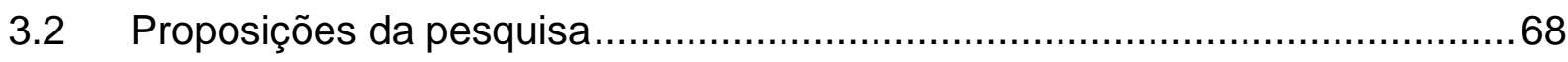

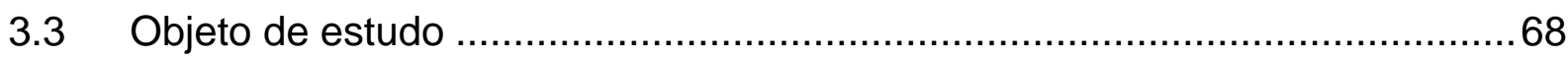

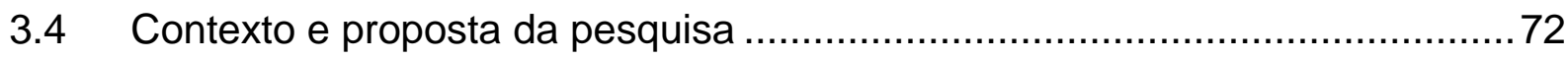

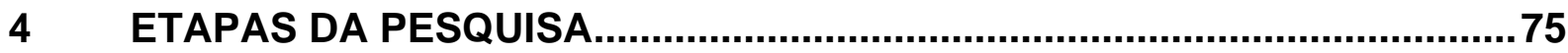

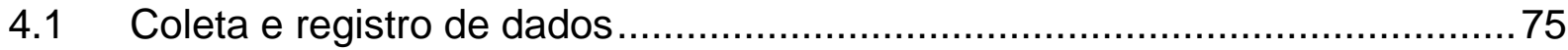

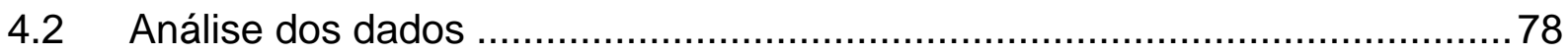

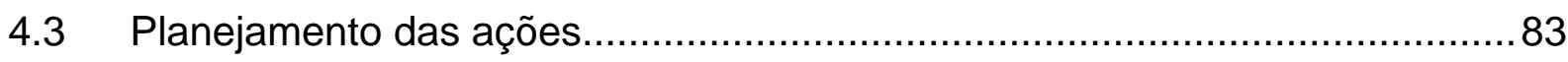

4.4 Implementação da ações ........................................................... 88

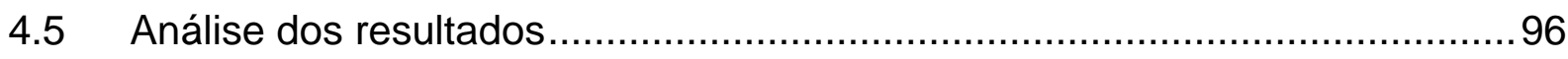

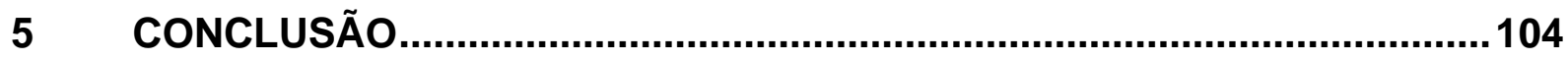

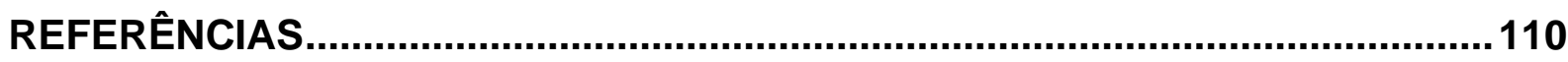




\section{LISTA DE TABELAS}

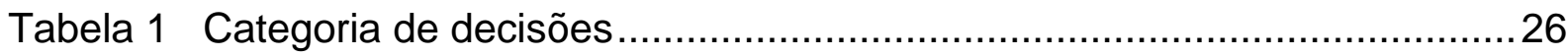

Tabela 2 Dimensões competitivas e medidas de desempenho............................30

Tabela 3 Fatores de influência no posicionamento do CODP ..............................34

Tabela 4 Correlação entre práticas do LM e dimensões competitivas ...................47

Tabela 5 Indicadores de complexidade de projetos ....................................49

Tabela 6 Roteiro de referência para a discussão e o desenvolvimento do projeto

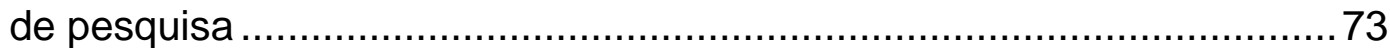

Tabela 7 Seleção de práticas do sistema LM............................................ 84

Tabela 8 Comparação de desempenho anterior versus posterior ........................ 102 


\section{LISTA DE ILUSTRAÇÕES}

Figura 1 Elementos da estratégia de manufatura...... 20

Figura 2 Diferentes políticas de atendimento da demanda relacionadas aos diferentes posicionamentos do CODP 33

Figura 3 Programas de manufatura associados ao sistema LM...........................37

Figura 4 Processo de implementação do sistema LM ......................................... 44

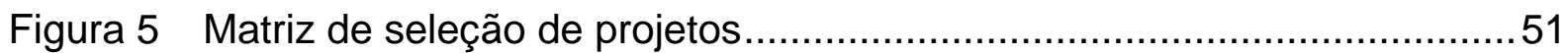

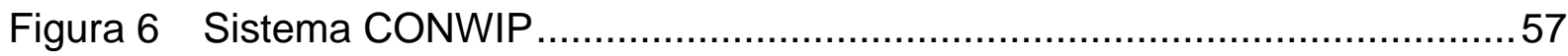

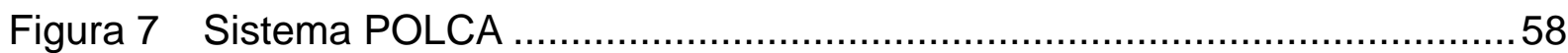

Figura 8 Hierarquia de planejamento e controle da WLC ...................................60

Figura 9 Relação de conceitos de PCP, produto, processo e atendimento da

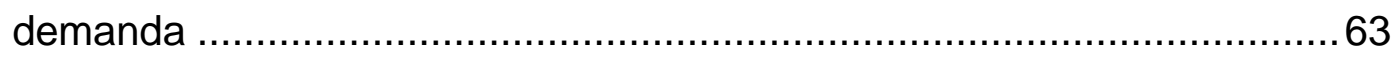

Figura 10 Avaliação da aplicabilidade das alternativas de PCP ao ambiente MTO .64

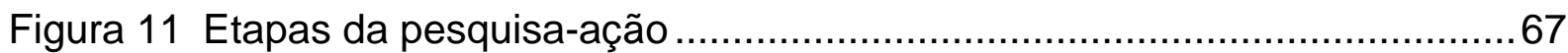

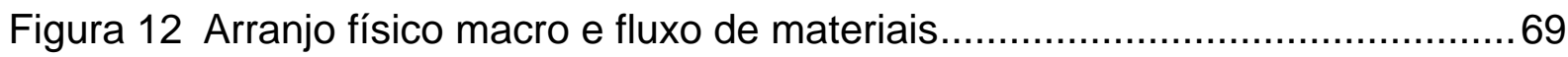

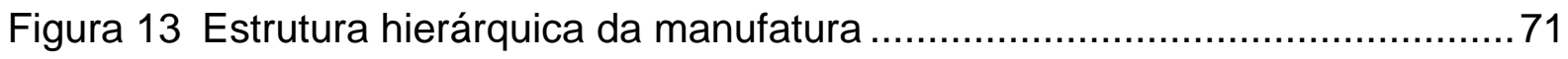

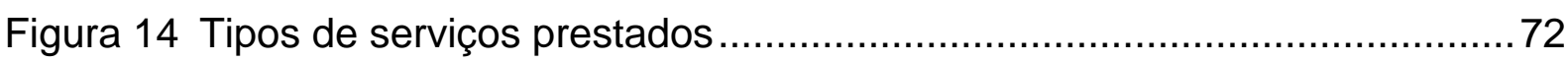

Figura 15 Diagrama causa-efeito (aderência ao prazo de entrega) ........................ 80

Figura 16 Diagrama causa-efeito (tempo de ciclo do pedido) ...............................80

Figura 17 Diagrama causa-efeito (eficiência da manufatura) …............................. 81

Figura 18 Matriz de seleção de práticas do sistema LM..................................... 87

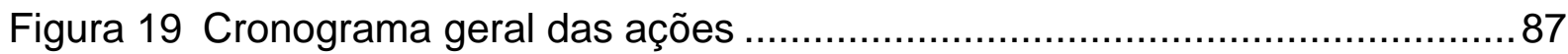

Figura 20 Cronograma de atividades (operadores polivalentes) ........................... 88

Figura 21 Cronograma de atividades (planejamento e controle da produção)..............90

Figura 22 Cronograma de atividades (manutenção autônoma)................................ 91

Figura 23 Cronograma de atividades (fornecimento JIT) ......................................93

Figura 24 Cronograma de atividades (redução do tempo de set-up) .......................94

Figura 25 Cronograma de atividades (projeto de máquinas)...................................95

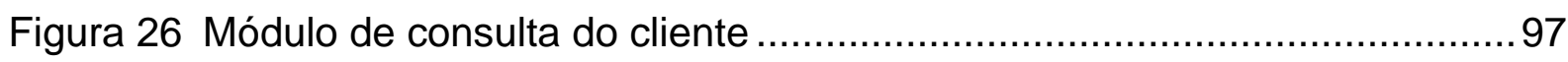

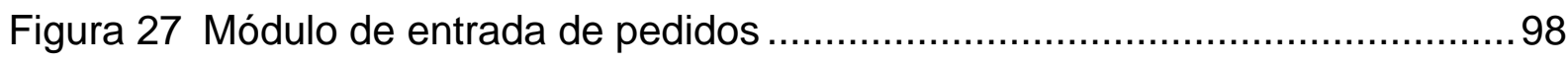

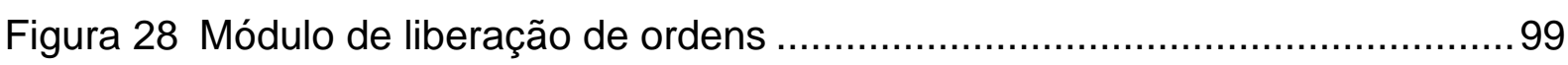




\section{LISTA DE GRÁFICOS}

Gráfico 1 Aderência ao prazo de entrega ................................................... 76

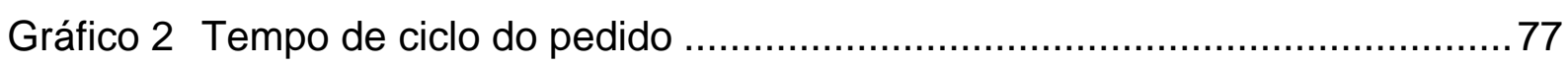

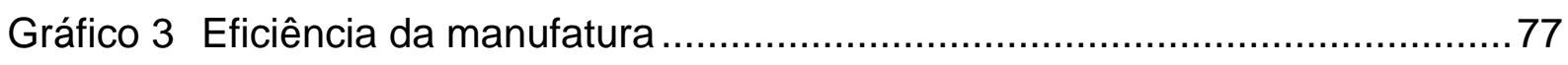

Gráfico 4 Eficiência da manufatura e principais perdas ..................................... 78

Gráfico 5 Aderência ao prazo de entrega após implementação .......................... 100

Gráfico 6 Tempo de ciclo do pedido após implementação ................................ 101

Gráfico 7 Eficiência da manufatura após implementação ................................. 101

Gráfico 8 Eficiência da manufatura e principais perdas após implementação .......102

Gráfico 9 Participação dos tipos de serviços nos volumes totais produzidos ........103 


\section{LISTA DE ABREVIATURAS}

$\begin{array}{ll}\text { AFT } & \text { Automated Flow Technology } \\ \text { ANS } & \text { Acordos de Nível de Serviço } \\ \text { ATO } & \text { Assemble-To-Order } \\ \text { CCK } & \text { Cálculo de Cartões Kanbans } \\ \text { CO } & \text { Cálculo de Operadores } \\ \text { CODP } & \text { Customer Order Decoupling Point } \\ \text { CONWIP } & \text { Constant Work in Process } \\ \text { CP } & \text { Common Practices } \\ \text { ERP } & \text { Enterprise Resource Planning } \\ \text { FIFO } & \text { First In / First Out } \\ \text { AHC } & \text { Arquitetura Hierárquica de Controle } \\ \text { HRM } & \text { Human Resource Management } \\ \text { JIT } & \text { Just-In-Time } \\ \text { LM } & \text { Lean Manufacturing } \\ \text { MOD } & \text { Mão-de-obra } \\ \text { MRP } & \text { Material Requirement Planning } \\ \text { MTO } & \text { Make-To-Order } \\ \text { MTS } & \text { Make-To-Stock } \\ \text { PCP } & \text { Planejamento e Controle da Produção } \\ \text { POLCA } & \text { Paired-cell Overlapping Loops of Cards with Authorization } \\ \text { POP } & \text { Procedimentos Operacionais Padrão } \\ \text { QRM } & \text { Quick Response Manufacturing } \\ \text { TPM } & \text { Total Productive Maintenance } \\ \text { TQM } & \text { Total Quality Management } \\ \text { WIP } & \text { Work-In-Process } \\ \text { WLC } & \text { Workload Control } \\ & \end{array}$




\section{Introdução}

\section{CAPÍtUlO 1}

A terceirização da manufatura é um fenômeno que tem crescido rapidamente no mercado mundial. Muitas empresas estão se concentrando no desenvolvimento de suas competências centrais e terceirizando parte ou todas as suas atividades de manufatura para prestadores de serviço, denominados manufatura contratada.

A competência central é qualquer atividade que uma empresa consegue fazer particularmente bem, atendendo a três requisitos: deve agregar valor ao cliente, ser de difícil imitação pelos concorrentes e permitir o acesso potencial a uma variedade de mercados. Tal habilidade pode ser encontrada em diferentes formas dentro de uma organização, normalmente associada a serviços intelectuais ou sistemas.

O crescente movimento da terceirização está relacionado com a visão de que esta pode auxiliar no aumento da competitividade das empresas e tem resultado em um enorme crescimento do número de prestadores de serviço de manufatura.

Para se alcançar o potencial máximo da terceirização, a empresa-cliente deve assegurar a existência de um alinhamento estratégico entre ela e o fornecedor. É desejável ter uma estratégia que promova as competências centrais dentro da organização, enquanto são promovidas competências complementares no fornecedor.

Este trabalho tem particular interesse na análise do desenvolvimento destas competências em uma empresa de manufatura contratada. As competências complementares aqui serão denominadas "competências operacionais" e definidas como habilidades desenvolvidas na manufatura para permitir que a organização se diferencie dos concorrentes e obtenha sucesso no mercado. 


\subsection{Justificativa da pesquisa}

Segundo Voss (2005), as competências operacionais da empresa de manufatura contratada devem estar significativamente relacionadas aos requisitos da empresa-cliente. O foco central da definição de uma estratégia para competir por meio da manufatura é alinhar suas competências aos requisitos de mercado; logo, as estratégias de manufatura passam a ser desenvolvidas a partir de prioridades competitivas da empresa derivadas dos requisitos do mercado. Estas incluem: baixo custo, alta qualidade, entregas rápidas e confiáveis, além de flexibilidade.

Para alcançar estes objetivos, a empresa deve tomar decisões e direcionar ações em termos de estrutura e infra-estrutura operacional que irão exercer um papel fundamental no desenvolvimento das competências operacionais.

Decisões estruturais são as que influenciam, sobretudo, as atividades de projeto (escolha do processo, instalações, capacidade e integração vertical), todas consideradas a longo prazo. Decisões infra-estruturais atuam sobre a força de trabalho, as atividades de planejamento, de controle e de melhoria da manufatura, considerados como "táticas", pois podem ser modificadas em um tempo relativamente curto (SLACK et al., 2002).

Segundo Souza e Voss (2007), as empresas de manufatura contratada sofrem uma forte influência das diversas empresas-cliente em vários níveis de decisão; por este motivo, evitam investir em um processo específico para um cliente. Ao invés disso, possuem operações organizadas para servir a uma série de clientes, produzir uma alta variedade de produtos e baixos volumes, o que tende a favorecer a adoção de um processo job-shop ${ }^{1}$.

\footnotetext{
${ }^{1}$ Job-shop: termo em inglês que significa o processo no qual uma quantidade específica de um produto é fabricada apenas uma vez (DAVIS et al., 2001).
} 
A forma de relacionamento com as empresas-cliente normalmente acarreta incertezas que envolvem tanto os tipos de produtos que serão fabricados como os volumes que serão demandados. Segundo Hallgren e Olhager (2006), estas incertezas reduzem a oportunidade de um planejamento antecipado da produção, requerendo, então, uma política de atendimento da demanda do tipo make-to-order (MTO). Na política MTO, os produtos são fabricados em resposta ao pedido do cliente e o grande desafio para empresas que operam neste ambiente é atender à demanda do cliente no prazo determinado.

Muitas empresas têm adotado programas de melhoria contínua, visando ao aprimoramento de seus processos de manufatura e ao desenvolvimento de competências operacionais capazes de diferenciá-las no mercado. Os programas JIT (Just-In-Time), TPM (Total Productive Maintenance), TQM (Total Quality Management) e HRM (Human Resource Planning) são comumente associados ao sistema Lean Manufacturing (LM) e suas práticas têm auxiliado as empresas a operarem com a política MTO em razão das reduções de lead time ${ }^{2}$ alcançadas quando implementadas (CUA et al., 2001; HOLWEG, 2005).

\subsection{Delimitação do problema}

Para Suri (2003), a aplicação de práticas do sistema LM tem produzido resultados expressivos em muitas empresas, sendo, portanto, considerada uma estratégia efetiva para o desenvolvimento de competências operacionais naquelas que operam em ambientes MTO. No entanto, alguns princípios e ferramentas de

\footnotetext{
${ }^{2}$ Lead time: termo em inglês que significa o tempo decorrido entre o início de uma atividade produtiva ou não e o seu término.
} 
planejamento e de controle da produção (PCP), como Kanban ${ }^{3}$, takt-time ${ }^{4}$ e nivelamento da produção, idealizados com base em uma demanda com relativa estabilidade, apresentariam muitos problemas com a alta variedade de produtos e baixos volumes.

Segundo Hines et al. (2004), do ponto de vista estratégico outras soluções podem ser integradas ao sistema LM sem contrapor o seu objetivo central, ou seja, fornecer valor ao cliente. A escolha de um sistema de PCP para atender às exigências de um ambiente - caracterizado pela alta variedade de produtos, baixo volume e alta variabilidade de demanda - deve estar baseada na sua capacidade de adaptação ao mesmo.

Neste sentido, os sistemas de PCP híbridos que adotam elementos de mais de um conceito (por exemplo, MRP - Material Requirement Planning / Kanban) possuem uma série de vantagens sobre o sistema Kanban tradicional. Entre os sistemas de PCP que atendem a estas características estão: AFT (Automated Flow Technology), CONWIP (Constant Work In Process) e POLCA (Paired-cell Overlapping Loops of Cards). Outro sistema especialmente projetado para atender às necessidades do ambiente MTO é conhecido como WLC (Workload Control).

O sistema de PCP a ser adotado, assim como as práticas do sistema LM, fazem parte da estratégia de manufatura e representam decisões que afetam a habilidade de alcançar os objetivos a longo prazo (OLHAGER; SELLDIN, 2007).

Desta maneira, conseguir um ajuste perfeito entre os requisitos do mercado, objetivos, práticas de manufatura e o sistema de PCP fornecem à empresa uma importante vantagem competitiva (VOLLMANN et al., 2005).

\footnotetext{
${ }^{3}$ Kanban: palavra japonesa que significa registro ou placa visível. Em Administração da Produção significa um cartão de sinalização que controla os fluxos de produção em uma indústria.

${ }^{4}$ Takt-time: termo em inglês que significa o tempo desejado entre unidade de produção, sincronizada à demanda dos clientes.
} 


\subsection{Objetivos da pesquisa}

\subsubsection{Objetivo geral}

Analisar como práticas do sistema LM podem ser efetivamente implementadas em conjunto a um sistema de PCP apropriado, visando ao desenvolvimento de competências operacionais alinhadas à política MTO.

\subsubsection{Objetivos específicos}

- Identificar na literatura as principais competências operacionais requeridas no ambiente MTO;

- Discutir o processo de implementação de práticas do sistema LM;

- Comparar conceitualmente os sistemas de PCP: AFT, CONWIP, POLCA e WLC quanto à sua aplicabilidade no ambiente MTO.

\subsection{Estrutura do trabalho}

Este trabalho está dividido em cinco capítulos, que compõem o processo de planejamento e execução da pesquisa.

No capítulo 1, apresenta-se uma breve introdução do tema, a justificativa da pesquisa, a delimitação do problema e a definição dos objetivos gerais e específicos.

No capítulo 2, revisa-se a literatura visando à construção de uma fundamentação teórica para tratar o tema e o problema de pesquisa. Neste capítulo 
são discutidos: a estratégia de manufatura, as decisões estratégicas em manufaturas contratadas, o sistema Lean Manufacturing e os sistemas de planejamento e controle da produção.

No capítulo 3, esclarece-se como e onde será realizada a pesquisa por meio da definição da metodologia, das proposições, da empresa objeto do estudo, do contexto e proposta da pesquisa.

No capítulo 4, descrevem-se as etapas da pesquisa-ação, os resultados são analisados com o objetivo de confirmar ou rejeitar as proposições de pesquisa.

Finalmente no capítulo 5, apresentam-se as conclusões do trabalho, tanto na confirmação ou não das proposições como no atendimento de seus objetivos. Ressalta-se também a contribuição da pesquisa para o meio acadêmico. 


\section{Revisão da Literatura}

CAPÍtulo 2

\subsection{Estratégia de manufatura}

\subsubsection{Elementos da estratégia de manufatura}

A estratégia de manufatura é definida por um padrão de decisões, estruturais e infra-estruturais, determinante das competências do seu sistema; também especifica como este irá operar no sentido de alcançar os objetivos da manufatura, obrigatoriamente consistentes com os da empresa (PLATTS et al., 1998).

Esta definição evidencia dois elementos principais da estratégia de manufatura: as decisões que determinam as competências do sistema de manufatura, e a existência de seus objetivos específicos, derivados de prioridades competitivas definidas pelos requisitos do mercado. $O$ conjunto de competências operacionais, desenvolvidas a partir de um histórico de decisões, indica os diferentes níveis de desempenho que podem ser alcançados por ela. Logo, as competências operacionais assemelham-se a um elo entre a estratégia e o desempenho da manufatura. A Figura 1 sumariza os principais elementos relacionados à estratégia de manufatura.

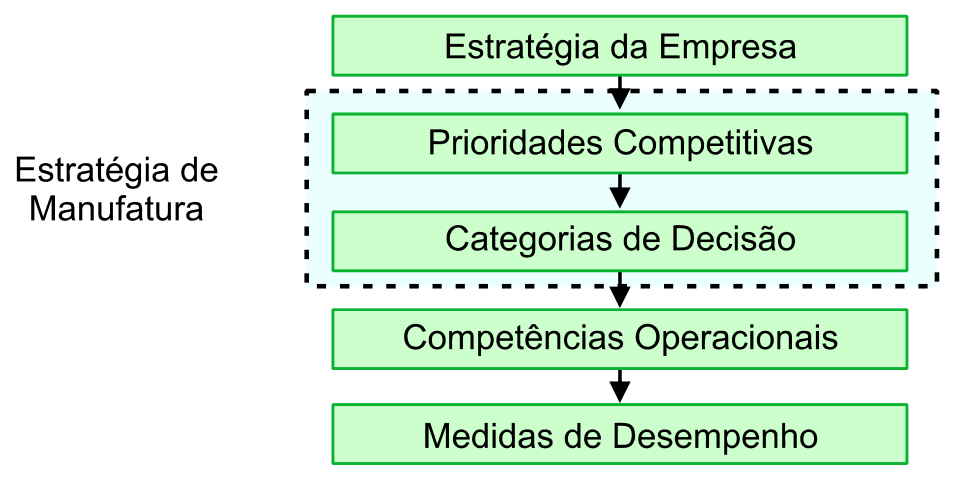

Fonte: adaptada de Hallgren e Olhager, (2006).

Figura 1 - Elementos da estratégia de manufatura 
Ward et al. (2007) definem a estratégia da empresa como um conjunto integrado e coordenado de compromissos e ações projetados para o desenvolvimento das competências centrais e para a obtenção de vantagens competitivas. A questão-chave que define a estratégia da empresa é: "Como deverse-ia competir no negócio?", ou seja, "Quais prioridades competitivas devem ser enfatizadas?"

As prioridades competitivas podem variar de mercado para mercado, porém é muito provável que se concentrem nos seguintes objetivos da manufatura: baixo custo, alta qualidade, entrega rápida e flexibilidade. Estas metas necessitam ser traduzidas em planos de ação para posterior execução, portanto o processo envolve identificar e avaliar as alternativas potenciais que conduzirão a empresa a alcançar os objetivos desejados (TAN; PLATTS, 2004).

Estas alternativas fazem parte das categorias de decisão, divididas em decisões estruturais (influenciam principalmente as atividades de projeto de uma empresa) e as de infra-estrutura (relacionadas à força de trabalho e às atividades de planejamento, de controle e de melhoria) (SLACK et al., 2002).

As competências operacionais são habilidades desenvolvidas na manufatura para permitir que uma empresa se diferencie dos concorrentes. Em conseqüência, por serem desenvolvidas internamente, tornam-se particularmente difíceis de serem copiadas ou transferidas, e, portanto, tornam-se valiosas (HAYES; PISANO, 1996). Logo, as competências operacionais derivam menos de fatores estruturais e mais de fatores infra-estruturais: pessoas, sistemas de gerenciamento e de informação, e aprendizado.

A correta visão das competências necessárias fornece uma base para a melhoria contínua além do simples alinhamento estratégico, posto que auxilia a continuidade de uma orientação estratégica ao longo do tempo. Assim, as iniciativas estratégicas devem procurar alavancar as competências existentes ou desenvolver as necessárias, que atualmente estão faltando. 
Segundo Platts e Tan (2004), uma atividade chave na formulação de uma estratégia é o entendimento do passado. Logo, a empresa deve possuir um sistema de mensuração de desempenho, indicando como a organização atingiu o seu estado atual e quais fatores têm impulsionado a condução da empresa ou mesmo falhado para a realização dos seus objetivos.

\subsubsection{Processo de formulação e implementação da estratégia de manufatura}

Tan e Platts (2004) sugerem ainda que, para se obter vantagem competitiva a partir da estratégia de manufatura, esta necessita ser formulada e posteriormente implementada. Uma vez que os objetivos da manufatura estejam estabelecidos, o próximo estágio é desenvolver os caminhos pelos quais eles serão alcançados. O processo de formulação e implementação da estratégia de manufatura é descrito abaixo:

- Definição dos objetivos da empresa: a abordagem hierárquica é normalmente adotada quando a estratégia de manufatura deriva da estratégia da empresa. Os objetivos desta podem incluir desenvolvimento de novos produtos, baixo custo, alto nível de customização dos produtos, etc.

- Seleção de famílias de produtos: os produtos podem ser agrupados em famílias de acordo com suas prioridades competitivas, seguidas pela formulação de uma estratégia de manufatura para cada conjunto. Tal estratégia poderá ser distinta, com a finalidade de servir o interesse da empresa.

- Avaliação das condições externas: esta é endereçada às exigências do mercado e à concorrência com o objetivo de determinar o que é requerido da empresa para atender a cada objetivo estratégico. Este estágio utiliza informações da área de marketing sobre o ambiente competitivo. 
- Avaliação das competências internas: considera as competências operacionais relacionadas à estratégia de manufatura existentes e às prioridades competitivas estabelecidas anteriormente, por exemplo custo, qualidade, entrega e flexibilidade. Neste estágio são avaliados o estado atual das instalações da manufatura, a tecnologia e a infra-estrutura em relação à estratégia de manufatura pretendida.

- Análise das lacunas existentes entre o desempenho atual e o desejado: uma comparação entre as auditorias internas e externas é efetuada com o objetivo de avaliar como as competências operacionais da empresas devem ser adequadas para atender aos critérios competitivos.

- Prioridade às questões-chave e definição dos objetivos da manufatura: este estágio utiliza os resultados da análise anterior para transformar as lacunas encontradas em um conjunto de prioridades e objetivos tangíveis.

- Definição da estratégia da manufatura: a partir da aplicação de técnicas de geração de idéias, como brainstorm ${ }^{5}$, desenvolve um conjunto de ações que poderiam ser implementadas. Se múltiplas opções forem possíveis, uma entre elas é escolhida para a implementação. A avaliação das alternativas pode ser subjetiva ou obtida pela utilização de modelos computacionais.

Muitas empresas utilizam grupos dedicados, apoiados pela alta gerência, para o desenvolvimento e implementação da estratégia de manufatura. Todas as áreaschave da empresa (Marketing, Finanças, Recursos Humanos e outras) devem estar envolvidas neste processo.

${ }^{5}$ Brainstorm: termo em inglês que significa "tempestade de idéias". Trata-se de uma técnica de discussão na qual um grupo contribui espontaneamente com idéias para solucionar um problema ou criar algo. 


\subsubsection{Prioridades competitivas}

O sucesso para o desenvolvimento da estratégia de manufatura efetiva está em compreender como criar ou agregar valor aos clientes. Especificamente o valor é agregado por intermédio de uma ou mais prioridades competitivas selecionadas para apoiar uma determinada estratégia.

Custo, qualidade, entrega e flexibilidade são largamente utilizados como dimensões competitivas da manufatura. Determinar quais delas a empresa deve enfatizar não é necessariamente o fator crítico de uma estratégia de manufatura, pois a empresa irá obter vantagens competitivas se, de maneira efetiva, traduzir os requisitos do mercado em padrões de decisões que auxiliem a desenvolver suas competências operacionais. Logo, o elemento crítico da estratégia de manufatura é traduzir requisitos do mercado em competências operacionais (BOYER; LEWIS, 2002).

A importância de cada dimensão para definição da prioridade competitiva é discutida abaixo:

- Custo: embora todas as empresas estejam preocupadas de alguma forma com o custo, a maioria delas não compete única ou mesmo principalmente sobre esta dimensão. As categorias relacionadas com o custo da manufatura incluem custos diretos da produção, produtividade, utilização da capacidade e redução de estoques.

- Qualidade: segundo Garvin (1987), podem-se identificar oito dimensões da qualidade: desempenho, característica, confiabilidade, conformidade, durabilidade, atendimento, estética e qualidade percebida. O controle de qualidade na manufatura tradicionalmente é focado sobre a conformidade, ou seja, o grau com que os produtos estão de acordo com os padrões préestabelecidos. Cada uma das outras dimensões pode representar bases para a competição, porém requer uma coordenação multifuncional dentro da empresa. 
- Entrega: as duas principais dimensões do seu desempenho são confiabilidade e velocidade. Confiabilidade é a habilidade de entregar produtos respeitando-se a data e quantidade requerida. Empresas que competem nesta dimensão destacam-se pela confiança na entrega e não necessariamente por terem baixo custo ou altíssima qualidade. Para alguns clientes, esta questão não é suficiente: a velocidade torna-se também necessária para ganhar o pedido.

- Flexibilidade: a importância estratégica da flexibilidade pode ser justificada por algumas situações, como o implemento do dinamismo das mudanças do mercado, a variedade das necessidades dos clientes, além do aumento da competitividade que impulsiona as empresas a se adaptarem a numerosas condições.

Para Holweg (2005), a habilidade do sistema de adaptar-se a mudanças externas e influências internas tem sido reconhecida como uma importante vantagem competitiva. O conceito de flexibilidade do sistema é baseado na hierarquia de diferentes tipos, incluindo operação, operadores, fornecedores e tecnologia. Evidenciando-se esta questão, diferentes empresas irão necessitar de diferentes tipos de flexibilidade para atenderem aos requisitos do mercado. A flexibilidade de volume pode contar com a habilidade da operação de mudar a alocação dos operadores rapidamente (flexibilidade de operadores). Uma empresa cujos clientes habitualmente solicitam mudanças de datas de entrega pode requerer um alto nível de flexibilidade de entrega e, conseqüentemente, uma rede de suprimento flexível (flexibilidade de fornecedores).

Uma vez que a empresa tenha definido suas prioridades competitivas, esta deve tomar decisões corretas para alcançar seus objetivos. Estas decisões são freqüentemente divididas em categorias de decisões (OLHAGER; RUDBERG, 2003). 


\subsubsection{Categorias de decisão}

A essência de uma estratégia de manufatura pode ser caracterizada como um padrão de decisões que afeta a habilidade da manufatura para alcançar os objetivos a longo prazo; estas são freqüentemente agrupadas em categorias, usualmente referenciadas como categorias de decisões (OLHAGER; RUDBERG, 2003). Desde que Hayes e Wheelwright (1984) primeiramente apresentaram o conceito, vários autores têm contribuído para o desenvolvimento e o estabelecimento de um conjunto de categorias de decisões. Rudberg e Olhager (2003) fornecem um resumo delas como apresentado na literatura e apontam que a divisão em estruturais e infraestruturais propostas por Hayes e Wheelwright (1984) ainda é válida. A Tabela 1 apresenta as principais categorias de decisão:

Tabela 1 - Categoria de decisões

\begin{tabular}{|c|c|c|}
\hline \multicolumn{2}{|c|}{ Categorias de decisão } & Políticas \\
\hline Estrutural & $\begin{array}{l}\text { Escolha do processo. } \\
\text { Instalações. } \\
\text { Capacidade. } \\
\text { Integração vertical. }\end{array}$ & $\begin{array}{l}\text { Processo, tecnologia, integração. } \\
\text { Tamanho, localização, foco. } \\
\text { Nível, tipo e incremento. } \\
\text { Direção e extensão. }\end{array}$ \\
\hline Infra-estrutural & $\begin{array}{l}\text { Gestão do fluxo de materiais. } \\
\text { Medidas de desempenho. } \\
\text { Organização. } \\
\text { Qualidade. }\end{array}$ & $\begin{array}{l}\text { Sistema de administração da produção. } \\
\text { Indicadores, métodos de medidas. } \\
\text { Recursos humanos. } \\
\text { Definição, padrões, ferramentas. }\end{array}$ \\
\hline
\end{tabular}

Fonte: adaptado de OLHAGER e RUDBERG, (2003).

Segundo Slack et al. (2002), as decisões estruturais influenciam principalmente as atividades de projeto, enquanto as infra-estruturais influenciam a força de trabalho de uma empresa, as atividades de planejamento, de controle e de melhoria. As primeiras estabelecem o potencial de desempenho da manufatura, ou seja, os limites dentro dos quais ela pode trabalhar. Já as infra-estruturais, envolvendo atividades de planejamento e de controle da produção, visam a conciliar as capacidades de fornecimento da manufatura com a demanda colocada sobre ela. Logo, as decisões tomadas para planejar e controlar uma operação produtiva 
dependerão tanto da natureza da demanda como da natureza do fornecimento em tal processo.

As decisões estruturais e infra-estruturais exercem um importante papel no desenvolvimento específico de competências operacionais a longo prazo, uma vez que direcionam melhorias contínuas na manufatura e refletem mudanças em sua estratégia.

\subsubsection{Competências operacionais}

Competências operacionais são habilidades desenvolvidas na manufatura para permitir que a empresa se diferencie dos concorrentes e obtenha sucesso no mercado (CHASE et al., 2006). O desenvolvimento, a manutenção ou o abandono de competências operacionais são os principais componentes da estratégia de manufatura.

Boyer e Lewis (2002) sugerem as seguintes competências operacionais para as quatro dimensões competitivas:

- Custo: habilidade de reduzir os estoques, aumentar a utilização da capacidade, reduzir os custos de produção e aumentar a produtividade dos operadores.

- Qualidade: habilidade de fornecer produtos de alto desempenho, melhorar a conformidade com o projeto e aumentar confiabilidade do produto.

- Entrega: habilidade de fornecer entregas rápidas, assegurar a aderência aos prazos e reduzir o tempo de produção.

- Flexibilidade: habilidade de ajustar a capacidade com prontidão, fazer rápidas mudanças de volume, ajustar o mix de produção e ainda oferecer uma larga variedade de produtos. 
O conceito de competências operacionais, o qual determina a contribuição da manufatura para o sucesso da empresa, é significativamente relacionado à noção de recursos, habilidades e prioridades. Recurso, ao contrário de competências, é tudo aquilo que a empresa possui ou tem acesso, e não o que a empresa está apta a fazer. Recursos podem ser tangíveis (por exemplo, um sistema de produção especializado) e intangíveis (como o nível de treinamento dos operadores). Baseadas nestes recursos são desenvolvidas as competências. Por exemplo, um sistema de produção flexível, aliado a operadores polivalentes (recursos), habilita a manufatura a produzir de forma flexível (competência).

As competências permitem à empresa desenvolver e explorar os recursos de forma a gerar lucro por meio de seus produtos e serviços. Um perfeito alinhamento entre os recursos disponíveis e as competências utilizadas é necessário para se atingir um alto grau de desempenho operacional (GRÖBLER; GRÜBNER, 2006).

As competências operacionais são cruciais para a empresa obter vantagem competitiva no mercado, porém, muitas vezes, não se mostram suficientes. Uma empresa pode ser capaz de produzir seus produtos a custos baixíssimos, no entanto não terá sucesso caso o preço do produto for apenas um critério qualificador e não um ganhador de pedidos. Outras empresas podem facilmente obter melhores resultados concentrando suas competências em outros critérios, como flexibilidade ou entrega (HILL, 2000).

Em um mercado sem restrições, é bastante claro que todas as competências operacionais deveriam ser melhoradas indefinidamente, porque isto ofereceria várias possibilidades de competição à empresa. Porém, os recursos são limitados e a gerência deve sempre tomar decisões baseadas no regime de recursos finitos; assim, nem todas as competências podem ser maximizadas. Esta visão é suportada pelo conceito de trade-off (SKINNER, 1985): uma competência só pode melhorar em detrimento de outra. A idéia principal é que, para a manufatura fornecer um alto nível de desempenho em todos os critérios competitivos é exigido um alto nível de 
complexidade em seu sistema de metas, gerando contradições e falta de direcionamento dos recursos.

Inversamente, alguns autores questionam que os trade-offs existem entre diferentes dimensões competitivas, ou seja, modernos sistemas de manufatura permitem melhorias em mais de uma dimensão simultaneamente. A habilidade de produzir a baixo custo pode ser suportada pelo bom resultado de desempenho em outras competências, como alta qualidade e processos confiáveis. Hayes e Pisano (1996) ressaltam que muitas empresas japonesas alcançaram, ao mesmo tempo, um elevado desempenho em custo, qualidade, entrega e flexibilidade por intermédio da implementação de princípios e de ferramentas do Lean Manufacturing.

\subsubsection{Medidas de desempenho}

Medir o desempenho é o processo de quantificar ações, no qual medir significa o processo de quantificação e o desempenho da manufatura é presumido como derivado de ações tomadas por sua gerência. As necessidades do mercado e as expectativas de cada objetivo de desempenho vão variar conforme descrito nos itens anteriores.

As quatro dimensões competitivas, custo, qualidade, entrega e flexibilidade, são compostas por medidas menores. Por exemplo, o custo de uma operação é derivado de muitos fatores, incluindo a eficiência com a qual converte os materiais, a produtividade dos operadores, etc. Todos estes fatores, individualmente, fornecem uma visão parcial do desempenho dos custos da manufatura, o que poderia ser útil para identificar áreas de melhorias, assim como para monitorar a extensão das melhorias (SLACK et al., 2002). A Tabela 2 fornece algumas medidas de desempenho típicas: 
Tabela 2 - Dimensões competitivas e medidas de desempenho

\begin{tabular}{ll}
\hline \multicolumn{1}{c}{ Dimensões competitivas } & \multicolumn{1}{c}{ Medidas de desempenho } \\
\hline Custo & - Utilização dos recursos. \\
& - Eficiência. \\
& - Produtividade dos operadores. \\
& - Custo por hora de operação. \\
& - Valor agregado. \\
& \\
Qualidade & - Número de defeitos por unidade. \\
& - Nível de reclamações do cliente. \\
& - Nível de refugo. \\
& - Tempo médio entre falhas. \\
& - Tempo de ciclo do pedido. \\
Entrega & - Freqüência das entregas. \\
& - Tempo de cotação do cliente. \\
& - Atraso médio dos pedidos. \\
& - Aderência ao prazo de entrega. \\
& - Tempo de mudança de máquina. \\
Flexibilidade & - Tamanho médio do lote. \\
& - Tempo para aumentar a capacidade. \\
& - Tempo para mudar as programações. \\
\hline
\end{tabular}

Fonte: adaptada de Slack et al., (2002).

O próximo passo a ser seguido pela empresa após a implementação de um sistema de mensuração de desempenho é analisá-lo qualitativamente. Existem quatro formas de se fazer isto:

- Padrões históricos: comparação entre o desempenho atual e os anteriores.

- Padrões de desempenho alvo: estabelecimento arbitrário para refletir um nível de desempenho considerado adequado ou razoável.

- Padrões de desempenho da concorrência: comparação entre o desempenho atingido e o apresentado por um ou mais concorrentes.

- Padrões de desempenho absoluto: consideram seus limites teóricos. Por exemplo: o padrão de qualidade "zero defeitos".

Segundo Tangen (2004), as informações recebidas de um sistema de mensuração de desempenho devem ser acuradas, relevantes, fornecidas no tempo certo, além de apresentarem fácil acesso às pessoas que delas necessitarem. 


\subsection{Decisões estratégicas em manufaturas contratadas}

Para realizar o potencial máximo de terceirização, as empresas contratantes deveriam assegurar a existência de um alinhamento estratégico entre elas e o(s) fornecedor(es); além disto, este(s) deveria(m) possuir as competências operacionais que as primeiras procuram. Segundo Voss (2005), as competências operacionais da contratada devem estar significativamente relacionadas aos requisitos da contratante. Portanto, o foco central da definição de uma estratégia para competir por intermédio da manufatura é alinhar as suas competências aos requisitos do mercado.

Souza e Voss (2007) ressaltam que as empresas de manufatura contratada são submetidas a uma forte influência dos clientes (empresas contratantes) em vários níveis de decisão; estes, inclusive, são freqüentemente desequilibrados a favor do cliente. Uma importante área de influência relaciona-se ao lead time de introdução de novos produtos, geralmente determinado pela estratégia de marketing do cliente para a qual a manufatura contratada necessita responder com altos níveis de flexibilidade. Outra área que o cliente influencia é a seleção de fornecedores e componentes; mesmo que os clientes não forneçam os componentes, podem impor ao contratado a escolha do fornecedor. Finalmente, os clientes têm forte influência sobre os planos de produção: com a proliferação de conceitos de minimização de estoques, as empresas de manufatura contratada reiteradamente têm que operar com pequenos lotes e entregas freqüentes, trabalhando conforme os planos de produção elaborados pelo cliente.

A partir de uma perspectiva estratégica, e pelo fato de o projeto do produto permanecer com o contratante, as empresas de manufatura contratada evitam investir em um processo específico para um cliente. Ao invés disto, possuem operações organizadas para servir a uma gama deles, e tendem a empregar ativos genéricos para atender a diversas especificações dos clientes. No âmbito operacional, este posicionamento estratégico resulta na possibilidade de operar com 
uma alta variedade de produtos e baixos volumes, favorecendo a adoção de um processo job-shop (SOUZA; VOSS, 2007).

\subsubsection{Políticas de atendimento da demanda}

As empresas de manufatura diferem na maneira de atender à demanda do cliente. Algumas entregam seus produtos por meio de um estoque de produtos acabados, produzidos antecipadamente ao pedido do cliente, make-to-stock (MTS); outras, no entanto, produzem somente em resposta ao pedido, make-to-order (MTO) (HASKOSE et al., 2004).

A decisão entre produzir para estoque ou contra o pedido é estratégica, baseada no tipo de serviço que a empresa objetiva fornecer aos seus clientes. Assim, a maneira como ela compete em seu mercado, as vantagens competitivas que deve sustentar para atingir uma posição de destaque e a forma de organização devem, certamente, influenciar este posicionamento.

O conceito de Customer Order Decoupling Point (CODP), ou ponto de desacoplamento do pedido do cliente, é freqüentemente utilizado para definir quais atividades da manufatura serão executadas antecipadamente e quais serão executas em resposta ao pedido. Este conceito está baseado na relação P:D introduzida por Shingo (1981), na qual $P$ corresponde ao lead time da operação incluindo os tempos de obtenção de todos os insumos, tempos de fabricação, de montagem e de entrega - e $D$ corresponde ao lead time de entrega, ou seja, o tempo que o cliente espera desde a colocação do pedido até o recebimento do produto. Dividindo-se os tempos $P$ por $D$, é possível determinar a proporção de atividades de planejamento e produção que devem estar baseadas em previsões e a proporção de atividades baseadas nos pedidos do cliente (WIKNER; RUDBERG, 2005). 
$\mathrm{Na}$ literatura são sugeridas e discutidas diferentes possibilidades de posicionamento do CODP e suas características remetem a, fundamentalmente, duas políticas: MTS e MTO. A estratégia assemble-to-order (ATO) pode ser vista como uma combinação destas duas, com o CODP separando-as. A Figura 2 apresenta o posicionamento do CODP nas diferentes políticas de atendimento da demanda.

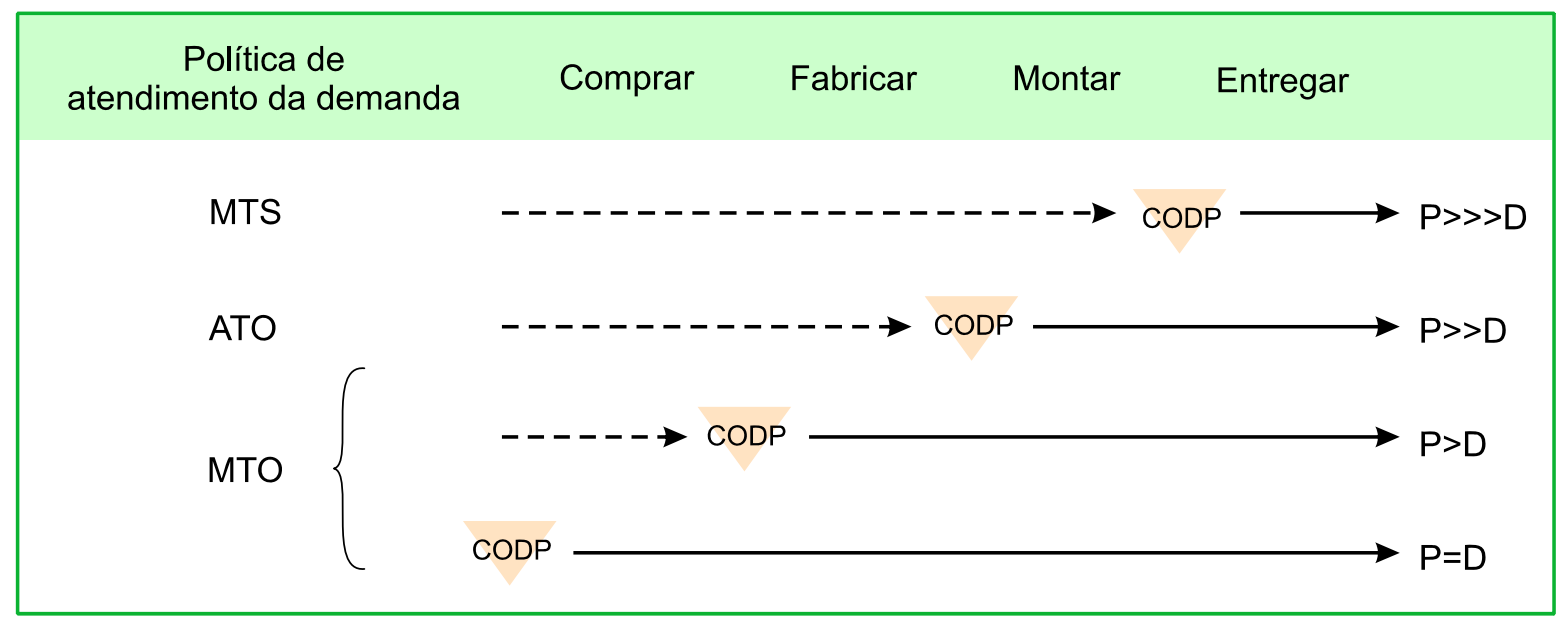

$----\rightarrow$ Atividades direcionadas pela previsão de demanda

$\rightarrow$ Atividades direcionadas pelo pedido do cliente

Fonte: adaptada de Olhager, (2003).

Figura 2 - Diferentes políticas de atendimento da demanda relacionadas aos diferentes posicionamentos do CODP

A figura acima demonstra duas possibilidades para a adoção da política MTO. $\mathrm{Na}$ primeira delas, a empresa possui estoques de matérias-primas e, portanto, o tempo total da operação $(P)$ é maior que o tempo de entrega (D); na segunda, a política MTO é implementada sem estoques de matérias-primas e, como conseqüência, o tempo total da operação é igual ao de entrega.

O posicionamento do CODP pode ser afetado por muitos fatores; Olhager (2003) dividiu-os em três categorias, conforme a Tabela 3: 
Tabela 3 - Fatores de influência no posicionamento do CODP

\begin{tabular}{ll}
\hline \multicolumn{1}{c}{ Categorias } & \multicolumn{1}{c}{ Fatores de influência } \\
\hline Mercado & $\begin{array}{l}\text { Lead time de entrega; variabilidade da demanda; volume / variedade de } \\
\text { produtos; tamanho / freqüência do pedido e sazonalidade da demanda. }\end{array}$ \\
Produto & $\begin{array}{l}\text { Projeto modular; oportunidade de customização oferecida; estrutura do } \\
\text { produto e complexidade da estrutura do produto. }\end{array}$ \\
Manufatura & $\begin{array}{l}\text { Lead time da operação; quantidade de centros de trabalho; flexibilidade; } \\
\text { localização do "gargalo" e tempos de set-up. }\end{array}$ \\
\hline
\end{tabular}

Fonte: adaptada de Olhager, (2003).

Estes fatores inter-relacionam-se de modo que as características do mercado afetem as características do produto. A variedade de produtos e a oportunidade de customização interagem com a expectativa do mercado, resultando no lead time de entrega que o cliente requer em relação ao produto oferecido. Estes fatores são direcionados à manufatura; assim, a estrutura do produto pode ser desmembrada em termos de lead time das operações que necessitam ser executadas em cada nível. A relação entre o lead time de operação e o lead time de entrega é o maior determinante do posicionamento do CODP (OLHAGER, 2003).

Wikner e Rudberg (2005) sugerem que o posicionamento do CODP tem implicações estratégicas, táticas e operacionais, pois afeta muitos aspectos da empresa. Por exemplo, caso haja uma falta de alinhamento entre o posicionamento do CODP assumido e o sistema de PCP, será muito difícil assegurar a eficiência da operação. Existem muitos exemplos de dificuldades enfrentadas por empresas que migram da política MTS para a MTO. Esta transição não requer somente uma adequação do seu sistema de PCP, mas também a introdução de práticas que assegurem o atendimento da demanda no menor tempo possível. 


\subsubsection{Competências operacionais relacionadas às políticas de atendimento da demanda}

Para as empresas que operam com a política MTS, a demanda é caracterizada por itens de alto volume, com quantidade relativamente estável e que pode ser prevista com alta precisão. As prioridades competitivas importantes neste ambiente são, além da qualidade, considerada um critério decisivo, a confiabilidade da entrega e o preço. Uma vez que custo é a prioridade dominante neste ambiente, a maioria dos esforços de melhoria de desempenho deveria incluir ganhos de produtividade; desta maneira, o desenvolvimento das competências operacionais deve estar focado na habilidade de fornecer produtos a baixo custo (HALLGREN; OLHAGER, 2006).

Segundo Hallgren e Olhager (2006), situações que requerem a política MTO são aquelas nas quais os produtos oferecidos são fabricados conforme especificação do cliente, reduzindo a oportunidade de um planejamento antecipado. As incertezas envolvem tanto os tipos de produtos que serão fabricados como os volumes a serem demandados, portanto, para lidar com esta situação, a empresa deve ser flexível em termos de capacidade e versatilidade. As competências operacionais importantes para este ambiente são a habilidade de fabricar produtos segundo a especificação do cliente assim como a de atingir lead times reduzidos e previsíveis. Alta confiabilidade na entrega é importante para manter a promessa ao cliente, enquanto reduzir os prazos de entrega pode ser um critério determinante para ganhar o pedido.

Empresas que operam com a política ATO freqüentemente produzem produtos semi-acabados ou módulos para um estoque intermediário onde os produtos acabados são montados em resposta ao pedido do cliente. Para estas empresas deveriam ser empregados dois focos: um voltado à produtividade e ao baixo custo para as atividades anteriores ao CODP, e outro direcionado à flexibilidade e à velocidade para as atividades posteriores. 
Dada a natureza dos produtos e o tipo de relacionamento com as empresas proprietárias da marca, muitas manufaturas contratadas optam por atender à demanda por intermédio da política MTO. O grande desafio para tais empresas é atender à demanda do cliente no prazo determinado. Logo, é necessário desenvolver competências operacionais que possibilitem a fabricação de produtos com lead times reduzidos e previsíveis. Para atingir este objetivo, as empresas têm adotado programas de melhoria contínua a fim de aprimorar seus processos de manufatura. Práticas do Lean Manufacturing têm auxiliado muitas delas a trabalharem com a política MTO devido às reduções de lead time alcançadas quando o sistema é implementado (HOLWEG, 2005).

\subsection{Lean Manufacturing}

O sistema LM é geralmente descrito a partir de dois pontos de vista. No aspecto mais geral, pode ser visto como uma filosofia (eliminação de desperdícios, envolvimento de todos e melhoria contínua) a qual pode ser utilizada para guiar as decisões e ações do gerente de manufatura na execução de diferentes atividades em contextos distintos. Ao mesmo tempo, trata-se de um conjunto de princípios e ferramentas que fornecem as condições operacionais para suportar esta filosofia (SLACK et al., 2002).

Cua et al. (2001) identificaram 17 práticas (Figura 3) comumente associadas ao sistema LM, classificadas em 4 programas de manufatura:

- JIT (Just-In-Time);

- TPM (Total Productive Maintenance);

- TQM (Total Quality Management);

- HRM / CP (Human Resource Management / Common Practices). 


\begin{tabular}{|c|c|c|}
\hline $\begin{array}{l}\text { JIT } \\
\text { - Redução do tempo de set-up } \\
\text { - Produção puxada } \\
\text { - Fornecimento JIT } \\
\text { - Arranjo físico } \\
\text { - Planejamento e controle } \\
\text { da produção }\end{array}$ & $\begin{array}{l}\text { TPM } \\
\text { - Manutenção autônoma e } \\
\text { planejada } \\
\text { - Ênfase em tecnologia } \\
\text { - Projeto de máquinas }\end{array}$ & $\begin{array}{l}\text { TQM } \\
\text { - Projeto do produto } \\
\text { - Gerenciamento do processo } \\
\text { - Gerenciamento da } \\
\text { qualidade do fornecedor } \\
\text { - Envolvimento do cliente }\end{array}$ \\
\hline \multicolumn{3}{|c|}{$\begin{array}{l}\text { HRM / CP } \\
\text { - Comprometimento da liderança } \\
\text { - Planejamento estratégico } \\
\text { - Operadores polivalentes } \\
\text { - Envolvimento das pessoas } \\
\text { - Informação e feedback }\end{array}$} \\
\hline
\end{tabular}

Fonte: adaptada de Cua et al., (2001).

Figura 3 - Programas de manufatura associados ao sistema LM

Os programas JIT, TPM e TQM têm como objetivo comum tornar o sistema de manufatura mais eficiente e eficaz por intermédio da melhoria contínua e da eliminação de desperdícios. As diferentes ênfases destes programas nestes dois quesitos são complementares e, reunidas, as diversas práticas devem auxiliar tanto na redução das atividades que não agregam valor como na redução da variabilidade dos processos. As práticas relacionadas ao programa HRM oferecem um mecanismo de suporte para a implementação dos diversos programas (CUA et al., 2001).

\section{Programa JIT}

Segundo Cua et al. (2001), o JIT é um programa de manufatura com o objetivo primário de continuamente reduzir ou eliminar todas as formas de desperdício. As duas maiores formas de desperdício são os estoques e os atrasos desnecessários no processo de produção; ambos podem ser reduzidos por meio da implementação de práticas relacionadas ao fluxo de produção, como a redução de tamanho de lotes, dos tempos de ciclo, as técnicas de set-up 
rápido, o arranjo físico celular, entre outras. As principais práticas relacionadas ao JIT são descritas a seguir:

- Redução do tempo de set-up: o tempo de set-up é definido como o decorrido entre a troca do processo da produção de um lote até a produção da primeira peça boa do próximo lote. Os tempos de set-up podem ser reduzidos por uma série de métodos: eliminação do tempo para busca e procura de ferramentas e equipamentos, pré-preparação de tarefas que retardam a troca, entre outras (SLACK et al., 2002). Para Davis et al. (2001), as economias no tempo de set-up são usadas para aumentar o número de lotes produzidos, com uma conseqüente redução do tamanho destes.

- Produção puxada: a idéia é que a produção trabalhe com base no reabastecimento conforme a demanda. Nesta lógica, os centros de produção "puxariam" a produção dos centros que fossem precedentes na seqüência do roteiro de fabricação (MIYAKE, 2002). O sistema Kanban está baseado no controle de fluxo de materiais que trabalha para o fluxo puxado, auxiliando, então, na redução dos níveis de estoque (DAVIS et al., 2001).

- Fornecimento JIT: os fornecedores devem estar integrados ao sistema de produção, além de realizarem entregas freqüentes e confiáveis. A variabilidade no suprimento ocorre quando estes falham ao não entregarem seus produtos no prazo, na quantidade e na qualidade corretos. Esta variabilidade pode ser gerenciada por intermédio da construção de uma base sólida de fornecedores confiáveis com contratos a longo prazo. Outra forma de limitar tal variabilidade é prover retornos regulares sobre o desempenho de qualidade e entrega, assim como treinamento e desenvolvimento para a melhoria contínua do processo (SHAH; WARD, 2003).

- Arranjo físico celular: trata-se do arranjo físico mais comum dentre as empresas que adotam o LM. As células são formadas pelos equipamentos necessários para processar completamente os componentes de determinada família, dispostos segundo o roteiro de fabricação preferencial característico deste grupo de produtos (CORRÊA; GIANESI, 1993). Segundo Suzaki (1987), o arranjo físico celular apresenta as seguintes vantagens: possibilita ao 
operador trabalhar em várias operações; permite transferir uma peça por vez; reduz os tempos de deslocamento, o material em processo e o lead time. Miyake (2002) lembra que este tipo de arranjo físico é uma opção atraente, no entanto nem sempre é possível implantá-lo e justificá-lo do ponto de vista econômico.

- Planejamento e controle da produção: a aderência ao plano de produção é a habilidade de atender às expectativas diárias de produção conforme o planejado. Os efeitos da variabilidade da demanda podem se propagar por todo o processo produtivo, causando, conseqüentemente, impactos negativos no plano diário de produção. Para conter os efeitos da variabilidade da demanda, são utilizadas ferramentas como takt-time (uma medida de quantidade requerida para atender à demanda do cliente), além de técnicas de nivelamento da produção, como o heijunka ${ }^{6}$ para adaptar as mudanças de demanda.

\section{Programa TPM}

O programa TPM visa a eliminar a variabilidade em processos de produção causada pelo efeito de paradas não-planejadas. Nakajima (1989) destaca cinco metas para uma boa prática de manutenção; são elas: melhoria da eficácia dos equipamentos; realização de manutenções autônomas; planejamento das manutenções; treinamento dos operadores em habilidades de manutenção relevantes; e gerenciamento dos equipamentos imediato ao início. Para Shah e Ward (2003), de forma geral, a ênfase sobre a manutenção pode também ser refletida pela importância dada à aquisição de

\footnotetext{
${ }^{6}$ Heijunka: é um conceito japonês relacionado à programação da produção com o qual um programa nivelado é obtido pelo seqüenciamento dos pedidos.
} 
novos equipamentos ou tecnologia. Desta forma, as práticas básicas do TPM são:

- Manutenção autônoma e planejada: implica capacitar o operador a realizar tarefas simples dentro de sua rotina de trabalho, permitindo que a equipe de técnicos de manutenção se ocupe de projetos de maior complexidade (MIYAKE, 2002). Planejar a manutenção significa ter uma abordagem inteiramente elaborada para a totalidade de suas atividades, devendo incluir o nível de manutenção preventiva necessário para cada equipamento, os padrões para a manutenção preditiva e as responsabilidades do pessoal da operação e de manutenção.

- Ênfase em tecnologia: o desenvolvimento da tecnologia eletromecânica impulsionou o desenvolvimento da automação nas indústrias, possibilitando operar seus processos de forma cada vez mais flexível. A "autonomação" (Jidoka) significa não somente automatizar máquinas e equipamentos, mas dotá-los de condições para operar de forma mais autônoma. O aumento do grau de "autonomação" de cada processo reduz a necessidade de o operador dedicar seu tempo para seu controle, aumentando-se a flexibilidade a fim de que ele cuide de um número maior de processos (MIYAKE, 2002).

- Projeto de máquinas: projeto ou seleção de novas máquinas ou melhoria nas já existentes de forma que possam operar de modo mais confiável, sejam mais fáceis de manter e, conseqüentemente, produzam melhor qualidade ao longo do tempo (SLACK et al., 2002).

\section{Programa TQM}

TQM é um programa de melhoria da manufatura que visa à melhoria contínua e à sustentação da qualidade de produtos e processos. Para tanto, investe esforços sobre o envolvimento da gerência, da força de trabalho, de fornecedores e de 
clientes, pretendendo atingir ou superar as expectativas dos clientes. Segundo Cua et al. (2001), quatro práticas são comumente citadas como parte de um programa de TQM; são elas:

- Projeto do produto: esta prática facilita a colaboração entre os projetos do produto e processo, visando obter o uso mais efetivo das tecnologias da manufatura. A prática inclui o projeto para manufatura, desenvolvimento de novos produtos e processo e equipe de desenvolvimento de projetos multifuncionais (SWINK et al., 2005).

- Gerenciamento do processo: o controle do processo está relacionado ao monitoramento da qualidade enquanto o produto está sendo produzido. Os objetivos das cartas de controle estatístico do processo são informar, enquanto os itens estão sendo produzidos, se os mesmos atendem as especificações de projeto, e detectar variações que sinalizem que os próximos produtos podem não atender aos requisitos do cliente (DAVIS et al., 2001).

- Qualidade do fornecedor: esta prática promove o envolvimento mais próximo com poucos e seletos fornecedores estabelecendo um relacionamento a longo prazo, sistemas de compartilhamento de informações, certificações, treinamentos e investimentos conjuntos (SWINK et al., 2005).

- Envolvimento do cliente: a cultura do cliente deve estar amplamente difundida em toda a empresa, a qual deve manter canais de comunicação que viabilizem um monitoramento contínuo da satisfação do cliente. A empresa deve ser capaz de identificar os fatores relacionados à satisfação do cliente e enfatizar a importância desses fatores na condução do negócio.

\section{Programa HRM}

A inclusão de práticas do programa HRM é de extrema importância para o sucesso da implementação do JIT, TPM e TQM. Estas permitem o desenvolvimento 
de um dos mais importantes recursos da empresa: o capital humano, imprescindível para a sustentar a flexibilidade, o aprendizado e a melhoria contínua (CUA et al., 2006). As principais práticas deste programa são:

- Comprometimento da liderança: direcionado à alta gerência, trata-se de um processo a longo prazo, direcionado para a melhoria contínua por intermédio da comunicação e do suporte na implementação dos programas de melhoria da manufatura (CUA et al., 2001);

- Planejamento estratégico: a estratégia de manufatura deve ser formulada, passando a representar um padrão de ações de forma que seu conceito seja compreendido e comunicado para a gerência e os operadores (PLATTS; TAN, 2004).

- Operadores polivalentes: o conceito de polivalência no trabalho é o oposto do conceito da especialização. A idéia da polivalência aplicada ao conteúdo do trabalho dos operadores pretende não restringir seu trabalho a tarefas específicas, simples, repetitivas e constantes no tempo, e sim capacitá-los a executar uma variedade maior de processos, tornando, conseqüentemente, a produção mais ágil e competitiva (MIYAKE, 2002).

- Envolvimento das pessoas: a filosofia do sistema LM é normalmente vista como um sistema "total", pois seu objetivo está relacionado ao fornecimento de diretrizes que incluam todos os empregados e todos os processos da organização. Uma cultura organizacional adequada tem sido vista como um importante fator para apoiar estes objetivos por meio da ênfase no envolvimento de todos os empregados da organização (SLACK et al., 2002).

- Informação e feedback ${ }^{7}$ : o principal objetivo de um sistema de mensuração de desempenho é fornecer informações importantes, no momento certo, para as pessoas certas. Um importante ponto a ser considerado relaciona-se ao fato de tal sistema, necessariamente, ser desenvolvido de forma que a informação

\footnotetext{
${ }^{7}$ Feedback: termo em inglês; significa informações ou declarações avaliativas sobre algo.
} 
seja facilmente recuperada, apresentada e entendida por aqueles cujo desempenho é avaliado (TANGEN, 2004).

O surgimento de programas de manufatura, como JIT, TPM e TQM, fornece evidências do crescente reconhecimento do papel estratégico desta função na organização. No entanto, o limitado sucesso na adoção deste programas é atribuído à constante falta de visão estratégica para a manufatura. "Apenas um terço de todos os programas de melhorias operacionais realizados foram considerados como sucesso" (Hayes et al., 2005). No intuito de obter o máximo benefício destes programas, é fundamental que as decisões tomadas na manufatura sejam coerentes com a estratégia da empresa (WARD et al., 2007).

\subsubsection{Processo de implementação do sistema LM}

Segundo Corrêa e Gianesi (1993), a implementação do sistema LM requer uma abordagem sistêmica na qual vários aspectos da empresa são modificados. Alguns deles são pré-requisitos para a implementação de tal sistema, entre os quais podem-se citar:

- comprometimento da alta administração: mudança para mentalidade enxuta;

- medição e avaliação de processos: indicadores de desempenho alinhados aos objetivos do LM;

- estrutura organizacional: especialistas devem capacitar os operadores a assumirem responsabilidades (por exemplo: qualidade, manutenção, etc);

- organização do trabalho: ambiente de trabalho que favorece a flexibilidade, comunicação e trabalho em equipe;

- conhecimento de processos e fluxos: compilação de fluxos de materiais e de informações; 
Hirano (1988) sugere outras etapas do processo de implementação do sistema LM, a saber:

- coleta de dados;

- análise do problema;

- delineamento de alternativas de soluções baseadas em princípios da metodologia Lean;

- desenvolvimento da solução com aproveitamento das práticas da metodologia Lean;

- implementação da solução;

- operação da solução.

A Figura 4 integra as principais idéias destas duas abordagens, auxiliando na definição do processo de implementação do sistema LM.

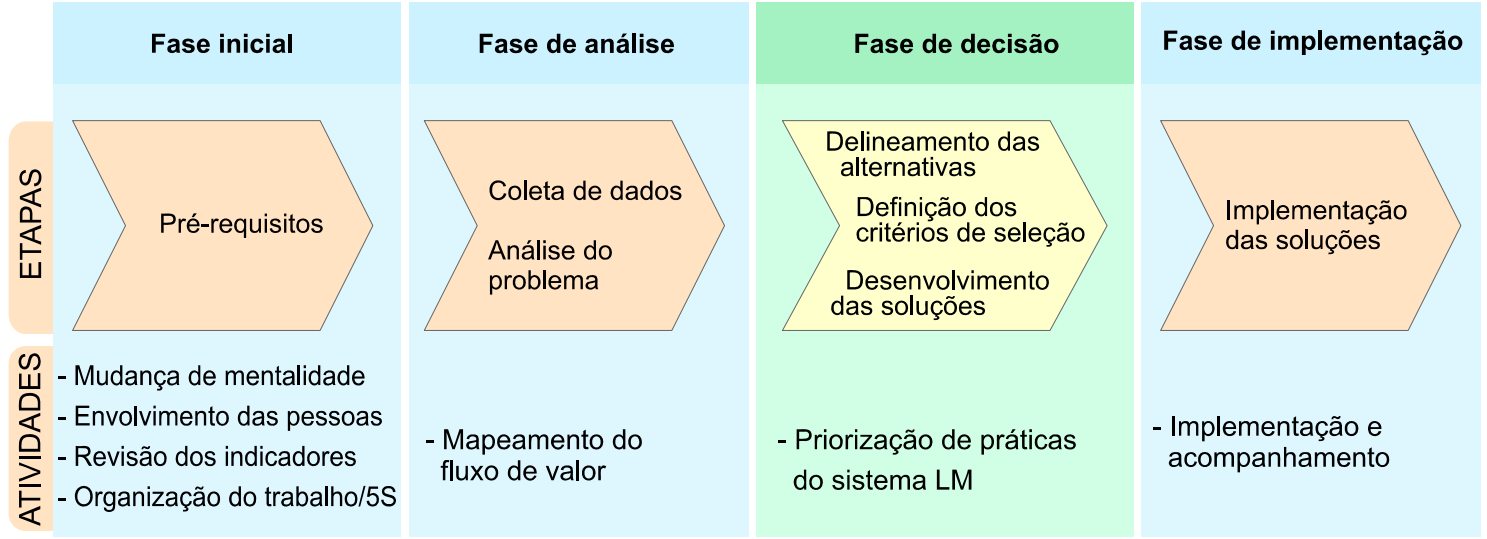

Fonte: Melchert et al., (2006).

Figura 4 - Processo de implementação do sistema LM 


\section{Fase inicial}

O sucesso da implementação do sistema LM não pode ser obtido sem uma mudança de atitude de toda a empresa. Hirano (1988) ressalta que, como líder de uma revolução dentro da empresa, o presidente deve mudar o seu jeito de pensar, assim como os operadores precisam aprender novos métodos por meio de reuniões diárias e seminários. Uma vez que toda mudança encontra resistência, é importante manter políticas e princípios claros. Assim, a melhoria do ambiente de trabalho deve fazer parte de um programa total de melhorias, logo o programa 5S's ${ }^{8}$ (arrumação, ordem, limpeza, conservação e disciplina) pode facilitar a promoção deste processo.

\section{Fase de análise}

Todo valor produzido por uma empresa é resultado de um processo complexo; trata-se de uma série de ações que os "pensadores Lean" chamam de fluxo de valor. O correto mapeamento do estado atual é um componente crítico no processo, pois os problemas de desempenho no fluxo de valor resultam do modo como este é configurado e gerenciado. Logo, suas melhorias podem ser baseadas somente na correta identificação dos problemas no estado atual; sendo assim, o mapeamento deve refletir esta situação (WOMACK, 2006).

Outras ferramentas, como "5 Porquês", diagrama "causa-efeito", "carta de processos múltiplos" e "matriz de incidência" também podem auxiliar na análise do problema (MIYAKE, 2002).

\footnotetext{
${ }^{8}$ 5S: provém de cinco palavras do idioma japonês iniciadas com a letra "S" (Seiri, Seiton, Seisou, Seiketsu, Shitsuke). É uma metodologia utilizada para melhorar a organização dos ambientes de trabalho, graças à mudança de atitude das pessoas ao seguirem os cinco passos recomendados pelo programa.
} 


\section{Fase de decisão}

A fase de decisão envolve o delineamento das alternativas, a seleção de práticas e o desenvolvimento da solução. Com a evolução contínua dos conceitos de LM, um grande número de práticas foi incorporado ao sistema, porém nem todas são vitais para cada caso de implementação. Logo, a seleção das ferramentas em certas aplicações é baseada em contextos específicos (PAPADOPOULOU; ÖZBAYRAK, 2005). Contextos específicos podem incluir:

- impacto sobre as dimensões competitivas;

- complexidade da implementação;

- investimentos relacionados à implementação.

\section{Fase de implementação}

Papadopoulou e Özbayrak (2005) ressaltam que, após a seleção e implementação do conjunto de práticas do LM, são necessários o acompanhamento e o comprometimento da alta gerência para que se alcancem os resultados esperados. Vale ressaltar que há diversas maneiras práticas direcionadas a este fim, como encorajar o time de trabalho, revisar ou corrigir o rumo, além de fornecer o apoio necessário para sustentar a mudança para o sistema LM.

\subsubsection{Impacto sobre as dimensões competitivas}

Diferentes práticas podem afetar dimensões competitivas específicas. Por exemplo, caso uma planta tenha como objetivo a redução de custo, um certo 
conjunto de ferramentas e práticas do TQM, JIT e TPM poderiam ser as mais aplicáveis; por outro lado, se desejasse alcançar altos níveis de qualidade, um diferente conjunto de práticas, incluindo as de TQM, poderiam ser as melhores. Um estudo conduzido por Cua et al. (2001) analisou o impacto de práticas específicas do TQM, JIT, TPM e HRM sobre a melhoria dos indicadores de desempenho, no qual as correlações forte, moderada e fraca foram pontuadas com os índices 5, 3 e 1 respectivamente. O resultado é demonstrado na Tabela 4:

Tabela 4 - Correlação entre práticas do LM e dimensões competitivas

\begin{tabular}{|c|c|c|c|c|c|}
\hline & & Custo & Qualidade & Entrega & Flexibilidade \\
\hline HRM & Comprometimento da liderança & 5 & 5 & 5 & 5 \\
\hline \multirow[t]{4}{*}{ I CP } & Planejamento estratégico & 3 & 5 & 5 & 1 \\
\hline & Operadores polivalentes & 5 & 3 & 5 & 3 \\
\hline & Envolvimento das pessoas & 5 & 5 & 5 & 1 \\
\hline & Informação e feedback & 5 & 3 & 5 & 1 \\
\hline \multirow[t]{4}{*}{ TQM } & Projeto do produto & 1 & 3 & 5 & 1 \\
\hline & Gestão do processo & 1 & 3 & 5 & 1 \\
\hline & Gestão da qualidade do fornecedor & 5 & 5 & 5 & 1 \\
\hline & Envolvimento do cliente & 3 & 1 & 3 & 5 \\
\hline \multirow[t]{5}{*}{ JIT } & Redução do tempo de set-up & 3 & 1 & 1 & 1 \\
\hline & Produção puxada & 3 & 1 & 3 & 1 \\
\hline & Fornecimento JIT & 5 & 5 & 3 & 3 \\
\hline & Arranjo físico & 1 & 1 & 1 & 1 \\
\hline & Planejamento e controle da produção & 3 & 3 & 5 & 3 \\
\hline \multirow[t]{3}{*}{ TPM } & Manutenção preventiva e autônoma & 5 & 3 & 3 & 1 \\
\hline & Ênfase em tecnologia & 5 & 5 & 5 & 5 \\
\hline & Projeto de máquinas & 1 & 1 & 1 & 1 \\
\hline
\end{tabular}

Fonte: adaptada de Cua et al., 2001.

As práticas relacionadas ao programa HRM apresentam uma correlação moderada / forte com a melhoria de desempenho em quase todas as dimensões competitivas. Conforme discutido anteriormente, elas fornecem o suporte para a implementação das diversas práticas do JIT, TPM e TQM, corroborando, portanto, a idéia de que o comprometimento da liderança, o envolvimento das pessoas e a medição e avaliação dos processos são pré-requisitos para a implementação do sistema LM (CORRÊA; GIANESI, 1993). 
É interessante notar que, em geral, as diversas práticas apresentaram uma correlação moderada / fraca com a melhoria da flexibilidade. Isto se deve ao fato de que a pesquisa estava focada na flexibilidade de volume, ou seja, a habilidade de a manufatura alterar o nível de produção. Em uma abordagem similar, Vokurka et al. (2007) avaliaram o impacto destas práticas sobre três diferentes tipos de flexibilidade: volume, produto e entrega. Os resultados da pesquisa confirmaram as diferentes correlações associadas aos diferentes tipos de flexibilidade. Práticas como redução do tempo de set-up e de planejamento e controle da produção apresentaram uma correlação mais forte com a flexibilidade de entrega, ou seja, com a habilidade de mudar as datas de entrega planejadas ou assumidas, que com a flexibilidade de volume.

\subsubsection{Complexidade e investimento envolvidos no processo de implementação}

A maioria dos pesquisadores reconhece que o processo de transformação para o sistema LM requer muito esforço, participação de todos os níveis hierárquicos, além da introdução de princípios, não somente no chão de fábrica, mas também na cultura e estrutura da empresa. Por estas razões, a transição pode ocorrer de forma lenta, incremental, complexa, portanto envolvendo um grande grau de incertezas quando não existe uma linha clara para a transição (PAPADOPOULOU; ÖZBAYRAK, 2005).

Segundo Miyake (2002), a complexidade e investimentos relacionados ao processo de implementações de práticas do sistema LM podem surgir em três níveis: 
- Projetos simples de impacto incremental: as mudanças a serem realizadas são geralmente fáceis, rápidas e de baixo custo (por exemplo, poka-yokes ${ }^{9}$, dispositivos para transferência de materiais, procedimento para limpeza e lubrificação, etc.);

- Projetos de média complexidade e impacto intermediário: requerem a interação da produção com o pessoal de outra(s) gerência(s); o valor do recurso que se pretende melhorar é intermediário, assim como os investimentos (por exemplo, Kanban, redução do tempo de set-up, arranjo físico celular, etc.);

- Projetos complexos e de grande impacto: seu propósito é estratégico, seu escopo é grande e o valor do recurso que se pretende melhorar é alto, assim como os investimentos (por exemplo, fornecimento JIT, set-up rápido para máquinas caras, revisão geral do arranjo físico, etc.).

Outra forma de avaliar a complexidade na implementação de projetos está demonstrada na Tabela 5:

Tabela 5 - Indicadores de complexidade de projetos

\begin{tabular}{|c|c|c|}
\hline Baixa complexidade & Média complexidade & Alta complexidade \\
\hline $\begin{array}{l}\text { Programação de prazos simples } \\
\text { sem nenhuma dependência }\end{array}$ & $\begin{array}{l}\text { Programação de prazos com } \\
\text { poucas dependências }\end{array}$ & $\begin{array}{l}\text { Programação de prazos } \\
\text { complexa, com muitas } \\
\text { dependências }\end{array}$ \\
\hline Custo total baixo & Custo total intermediário & Custo total alto \\
\hline $\begin{array}{l}\text { Tecnologia, técnicas e processos } \\
\text { testados }\end{array}$ & - & $\begin{array}{l}\text { Tecnologia, técnicas e } \\
\text { processos não testados }\end{array}$ \\
\hline $\begin{array}{l}\text { Impacto em somente um } \\
\text { departamento }\end{array}$ & $\begin{array}{l}\text { Impacto em mais de um } \\
\text { departamento }\end{array}$ & $\begin{array}{l}\text { Extenso impacto em vários } \\
\text { departamentos }\end{array}$ \\
\hline $\begin{array}{l}\text { Envolve pessoas de um único } \\
\text { departamento }\end{array}$ & $\begin{array}{l}\text { Envolve pessoas de mais de um } \\
\text { departamento }\end{array}$ & $\begin{array}{l}\text { Envolve pessoas de muitos } \\
\text { departamentos }\end{array}$ \\
\hline
\end{tabular}

Fonte: elaborada pelo autor.

${ }^{9}$ Poka-yoke ("à prova de defeitos"): dispositivo ou mecanismo simples que, instalado na máquina ou no posto de trabalho, evita a ocorrência de erros, isto é, mesmo que a intenção seja fazer errado, o poka-yoke não permite. 
Um estudo conduzido por Lewis (2000) demonstra que cada empresa segue uma trajetória particular quando analisada a seqüência pelas quais as diferentes práticas do LM são implementadas. Duas observações principais deste estudo são: considerável variação do número, da duração e da complexidade de cada prática; e influência direta da seqüência de implementação nos resultados da empresa. Bhasin e Burcher (2006) sugerem que as grandes dificuldades enfrentadas pelas empresas ao tentarem implantar o sistema LM estão na falta de direção, de planejamento e de uma seqüência de projeto adequada.

\subsubsection{Matriz de seleção de projetos}

A seleção de projetos é descrita como um processo no qual uma combinação ótima de projetos candidatos é escolhida para a implementação baseada nos parâmetros considerados mais críticos. Em seguida, os projetos são selecionados e atribuem-se metas, recursos e prazos apropriados durante a fase de planejamento, atualizados durante a fase de execução. Devido às incertezas associadas ao custo, aos prazos e ao desempenho de um projeto na fase inicial, a seleção de um projeto particular dentre uma lista de projetos é uma tarefa difícil (JUNG; LIM, 2007).

Klastorin (2004) aponta fatores importantes a serem considerados como critérios de seleção de um novo projeto; são eles:

- consistência com as metas e a missão da empresa;

- contribuição para os objetivos estratégicos;

- impactos no fluxo de caixa - investimentos;

- impacto na carga dos recursos - complexidade.

A matriz de seleção de projetos é um documento que permite ao time ou ao indivíduo sistematicamente identificar, analisar e avaliar o peso da relação entre um 
conjunto de informações. Ela é, portanto, especialmente útil para identificar um número grande de fatores de decisão assim como para assinalar a importância relativa de cada um deles.

A utilização da matriz pode ser sumarizada conforme as seguintes etapas (por exemplo, Figura 5):

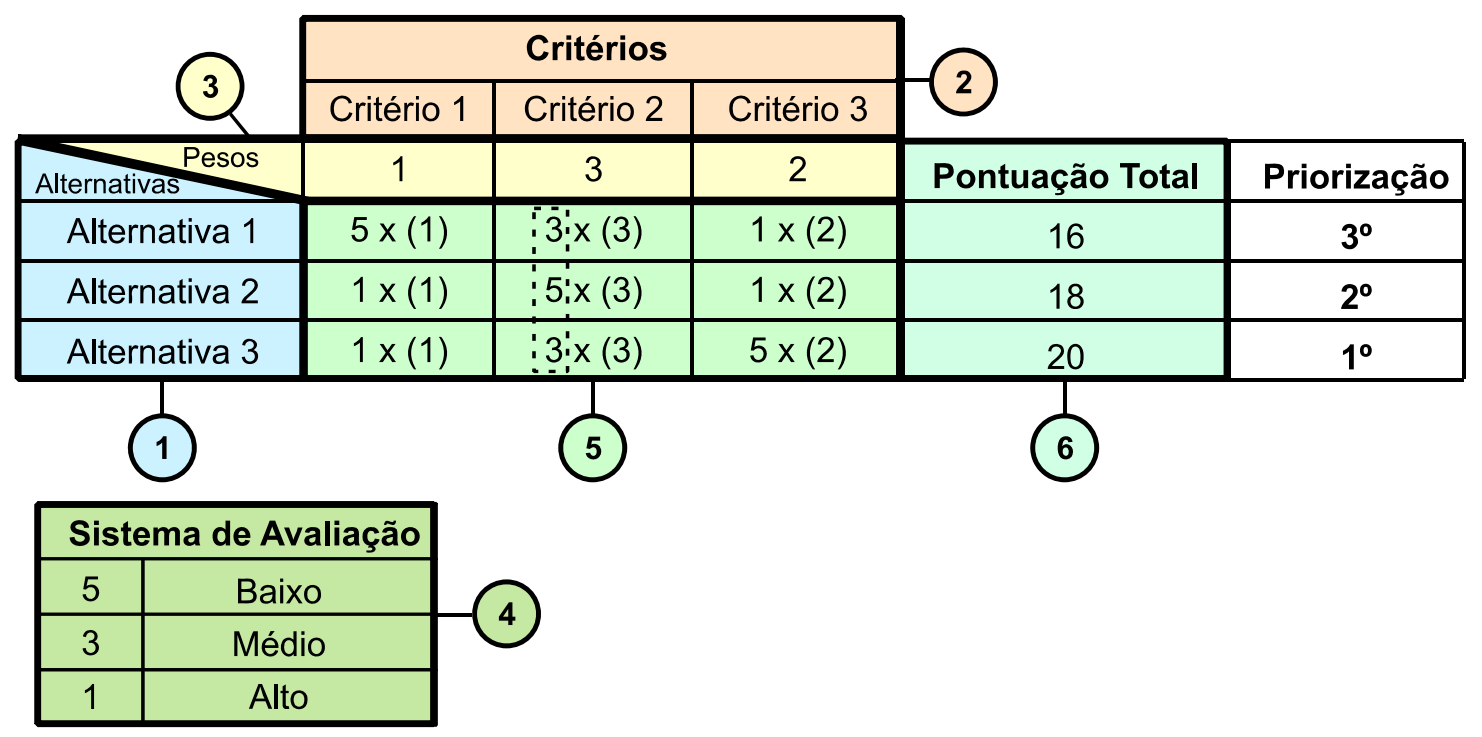

Fonte: elaborada pelo autor.

Figura 5 - Matriz de seleção de projetos

1. Identificação das alternativas: dependendo das necessidades da equipe, as alternativas podem ser etapas de um processo, projetos ou soluções potenciais;

2. Identificação dos critérios de seleção: os critérios-chave podem vir de um diagrama de afinidade prévio ou a partir de uma atividade de brainstorm. É importante assegurar que todos os participantes tenham um entendimento claro do significado de cada critério;

3. Atribuição de pesos: caso alguns critérios de decisão sejam mais importantes que outros, a equipe deve rever e concordar com o peso a ser atribuído para cada um deles (por exemplo, 1, 2, 3); 
4. Definição do sistema de avaliação: antes de avaliar as alternativas, a equipe deve concordar com seu sistema. Desta maneira, deve-se determinar a escala de pontuação (por exemplo, 1 a 5 ou 1, 3 e 5) e assegurar que todos os membros da equipe tenham um entendimento comum da representação das pontuações alta, média e baixa;

5. Avaliação das alternativas: a cada alternativa atribui-se uma pontuação relacionada a cada critério de decisão;

6. Totalização da pontuação: trata-se de multiplicar a pontuação de cada critério de decisão pelo seu peso; em seguida, totalizá-la para cada alternativa e analisar o resultado.

A matriz de seleção de projetos fornece um caminho simples e direto para reunir os dados apropriados à tomada de decisão, pois estabelece um sistema de pontuação e, finalmente, gera uma lista de prioridade para os projetos.

\subsubsection{Limitações do sistema LM}

O sistema LM é uma abordagem multidimensional que abrange uma larga variedade de práticas e representa a estrutura mais fundamental para atingir eficiência a partir da redução de desperdícios. A produção é enxuta caso seja realizada com o mínimo custo; a fonte menos óbvia de custo é a variabilidade, a qual pode ser encontrada em diversas formas: variabilidade do tempo de processo, do tempo de entrega, das taxas de rendimento, de demanda, entre outras (HOPP; SPEARMAN, 2004).

Hines et al. (2004) sugerem que o ponto crítico do LM esteja na habilidade de lidar com a variabilidade. As empresas pioneiras na implementação deste sistema pertenciam a uma cadeia de fornecimento com demanda relativamente estável; assim, o alto volume e a demanda repetitiva favoreciam a implementação da produção puxada (Kanban). Em muitos outros setores, a variabilidade da demanda 
era o principal inibidor do LM em geral, e do Kanban em particular. Como resultado, muitos pesquisadores propuseram soluções ágeis, introduzindo grande ênfase na negociação com a variabilidade da demanda dos clientes e utilizando ferramentas de tecnologia da informação.

Papadopoulou e Özbayrak (2005) apontam que uma importante questão a ser discutida é a utilização do potencial completo do sistema LM em ambiente de produção não repetitiva. Logo, pesquisas futuras deveriam se concentrar na aplicação das práticas do LM em ambientes MTO com foco particular sobre as funções de PCP, mesmo que sua implementação possa resultar em algum tipo de "customização".

A partir de um ponto de vista estratégico, outras soluções podem ser integradas ao sistema LM sem contrapor seu objetivo central - fornecer valor ao cliente. Em outras palavras, qualquer outro conceito que forneça valor ao cliente pode estar alinhado com - Lean Manufacturing, mesmo se algumas de suas práticas características de planejamento e controle da produção, como Kanban, produção nivelada e takt-time, não sejam adotadas. Portanto, existe uma grande variedade de abordagens que podem e têm sido utilizadas em conjunto ao sistema LM (HINES et al., 2004).

\subsection{Sistemas de planejamento e controle da produção (PCP)}

Henrich et al. (2004) sugerem que a escolha de sistema de PCP é uma decisão importante e crucial para o sucesso econômico da empresa. Diferentes estágios podem ser distinguidos em seu processo de seleção e implementação; são eles:

- estudo e avaliação preliminar;

- investigação detalhada e seleção final;

- implementação. 
No estudo e avaliação preliminar, uma pré-seleção entre as alternativas de PCP é realizada, em seguida são feitas uma investigação detalhada e a escolha final; porém, antes da implementação do conceito escolhido, uma investigação detalhada das características relevantes da empresa é necessária, assim como as características de um possível software são avaliadas. Finalmente, no estágio de implementação, as atividades do chão de fábrica necessariamente são adaptadas ao conceito escolhido, o pacote do software selecionado é parametrizado e incorporado à rotina gerencial.

\subsubsection{Requisitos do sistema de PCP voltados à política MTO}

Stevenson e Hendry (2006) sugerem que as funções típicas de um sistema de PCP incluem o planejamento e requisição de materiais, o controle de entradas e saídas, assim como o planejamento e o seqüenciamento das ordens de trabalho.

Segundo Soman et al. (2004), para empresas que operam em ambientes MTO, o foco do planejamento da produção está na execução das ordens. Algumas medidas típicas de desempenho incluem o atendimento aos prazos de entrega, o tempo médio de ciclo dos pedidos e o número de ordens em atraso. A principal vantagem competitiva é a redução do tempo de entrega. Planejamento da capacidade, aceitação e rejeição de pedidos, e atingir altos níveis de aderência aos prazos de entrega são as principais questões operacionais.

Stevenson et al. (2005) propõem os seguintes critérios para avaliar a aplicabilidade das alternativas de PCP ao ambiente MTO:

- inclusão de um estágio de consulta do cliente visando à proposta da data de entrega e ao planejamento da capacidade;

- inclusão de um estágio de entrada e liberação de ordens de produção com a finalidade de obter a aderência aos prazos de entrega; 
- habilidade de lidar com produções não repetitivas. Por exemplo, produtos altamente customizados;

- habilidade de prover planejamento e controle quando os roteiros de produção são variáveis;

- aplicabilidade em pequenas e médias empresas.

Segundo Melchert e Francischini (2005), a escolha do sistema de PCP para atender às exigências de um mercado caracterizado pela larga variedade de produtos e de demanda deve estar baseado na capacidade de adaptação dele a este ambiente. Neste sentido, os sistemas híbridos de PCP formados por elementos provenientes de duas ou mais lógicas (por exemplo, MRP / Kanban), possuem uma série de vantagens, pois, trabalham de forma integrada buscando capitalizar as vantagens e as vocações de cada sistema (CORRÊA et al., 2001).

Entre os sistemas de PCP que atendem a estas características estão o AFT, CONWIP e POLCA, descritos a seguir. Outro sistema especialmente projetado para atender às necessidades do ambiente MTO é conhecido como WLC (Workload Control).

\subsubsection{AFT}

AFT (Automated Flow Technology) é o sistema de Kanban automatizado, proposto por Louis (1997), que incorpora dois módulos de programação interligados ao sistema MRP. Estes módulos são: o programa de simulação e cálculo de cartões Kanbans (CCK) e o programa de cálculo de operadores (CO). O módulo do CCK utiliza as informações da necessidade bruta de cada produto produzido por uma célula, o lead time de ressuprimento e o seu estoque de segurança para o cálculo automático dos cartões Kanban. O módulo do CO utiliza as informações da demanda média diária, o tempo padrão por unidade do produto e o tempo efetivo de trabalho do operador por dia para o cálculo de operadores em cada célula de trabalho. 
Estas duas ferramentas permitem uma significativa redução nos custos da manufatura e a melhora do tempo de resposta ao cliente por meio da redução de atividades que não agregam valor. Estar suportado pelo conceito de Lean Manufacturing é o pré-requisito principal para o funcionamento do sistema. $\mathrm{O}$ sistema AFT também permite ao usuário a flexibilidade em selecionar quais produtos devem ser controlados por Kanban e quais devem ser controlados pelo MRP (LOUIS, 1997).

\subsubsection{CONWIP}

CONWIP (Constant Work In Process) é uma forma generalizada de Kanban. Segundo Spearman et al. (1990), este sistema configura-se como parte de uma arquitetura hierárquica de controle $(\mathrm{AHC})$; juntamente ao conceito de Lean Manufacturing promove um ambiente capaz de acomodar mudanças de mix, maior quantidade de set-ups, além de lotes menores de produção. No sistema CONWIP, os cartões percorrem um circuito que inclui a linha inteira: um deles é anexado a uma caixa padrão de peças no início da linha; quando a caixa é utilizada no final da linha, o cartão é removido e enviado de volta ao início da linha, onde aguarda em uma fila de cartões para eventualmente ser anexado a outra caixa de peças.

Os cartões são atribuídos a uma linha específica e não a um código de peça; já os códigos das peças são atribuídos no início da linha de produção. Quando uma produção é requerida, o cartão é removido de uma fila e marcado com o primeiro código de produto da seqüência de pedidos, normalmente gerada pelo sistema de MRP (SPEARMAN et al., 1990). As demais estações de trabalho estão sempre autorizadas a trabalhar sobre qualquer produto liberado pelo sistema, assim não há necessidade de haver cartões passando por estas máquinas. O princípio de funcionamento do sistema CONWIP é demonstrado na Figura 6: 


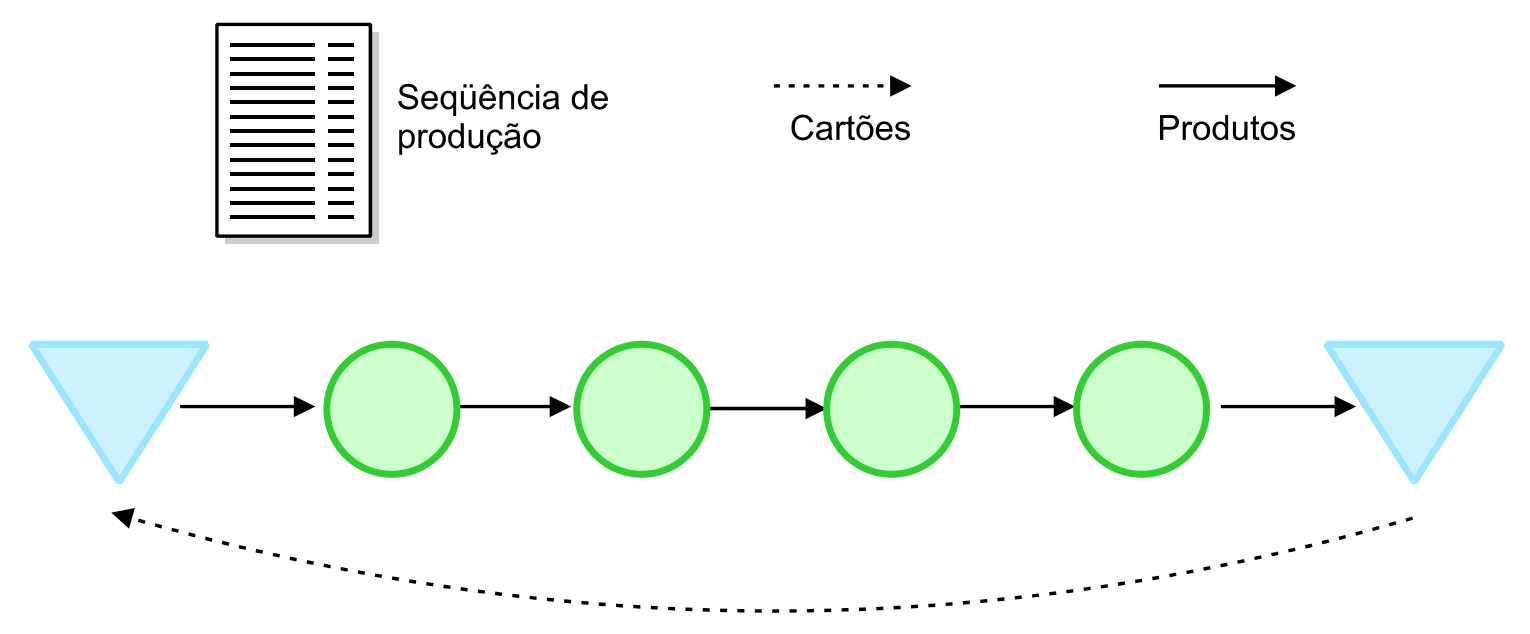

Fonte: Spearman et al. (1990).

Figura 6 - Sistema CONWIP

\subsubsection{POLCA}

POLCA (Paired-cell Overlapping Loops of Cards with Authorization) é um sistema híbrido de controle da produção suportado pela filosofia do QRM (manufatura de resposta rápida). Para compreensão das bases do sistema POLCA, deve-se considerar que as empresas de maior competitividade demonstram uma tendência à produção de customizados em pequenos lotes ou até unitários (MTO); por outro lado, há aquelas que não customizam, porém possuem uma larga variedade de produtos os quais não podem permanecer em estoque (MTO / ATO) (SURI, 2003).

A estratégia do QRM organiza a empresa em células focadas nos conjuntos de processos para produtos similares; assim, o pedido é processado pelas diferentes células, dependendo de sua necessidade. O sistema MRP é usado para o planejamento do produto final, coordenação do pedido de materiais aos fornecedores e também entre células, mas não entre as estações de cada uma delas. Os tempos de operação de cada unidade são colocados no 
sistema MRP, e esta informação é utilizada para programar as datas de entrega, assim como para determinar as datas de início do pedido em cada célula.

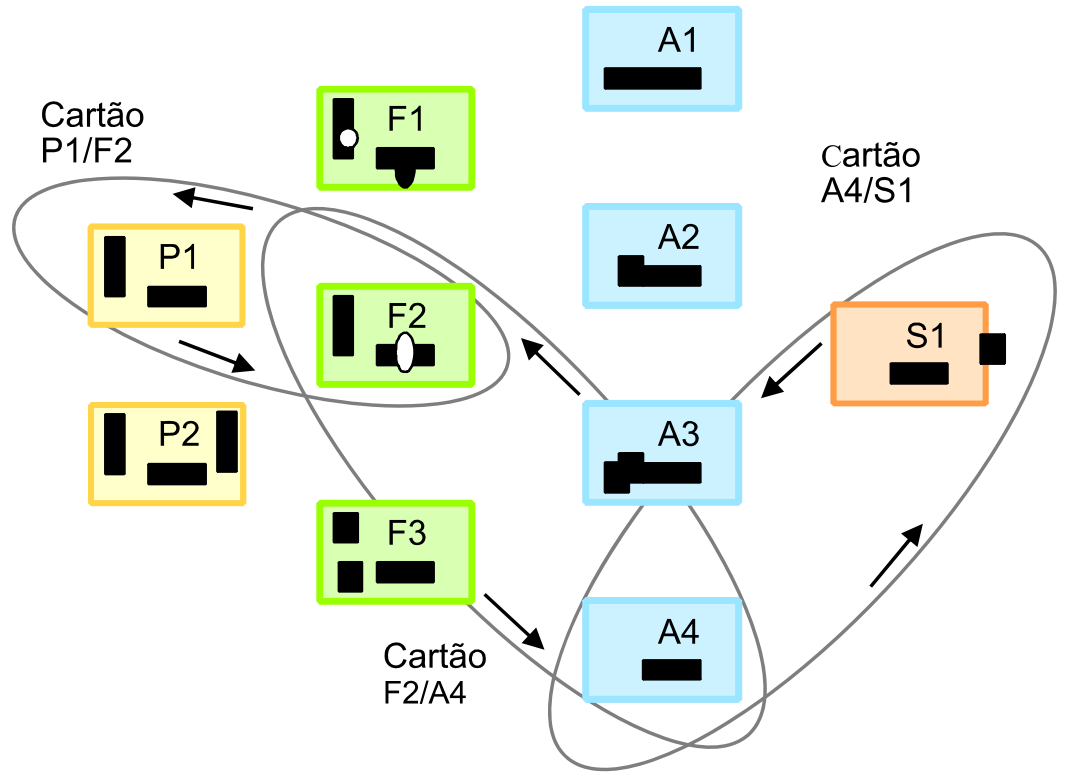

Fonte: Suri, (2003).

Figura 7 - Sistema POLCA

Conforme demonstrado na Figura 7 , os cartões de controle da produção relacionam-se a pares de células e não a um produto específico; outra informação necessária é que se deve usar a previsão de vendas a fim de agregar famílias, de modo a decidir qual rota pode ser usada (por exemplo, P1/F2/A4/S1), ou seja, o cartão POLCA P1/F2 permanece anexado ao produto até o processo ser concluído na célula $F 2$. Ao enviar o produto à célula $A 4$, o cartão $P 1 / F 2$ retorna à $P 1$, iniciando um novo ciclo de produção (SURI, 2003).

Para que se obtenha sucesso na implementação deste sistema, é necessário que seja permitida uma alta variabilidade de rotas de produção (STEVENSON et al., 2005). 


\subsubsection{Workload Control}

Workload Control é um conceito de PCP desenhado para ambientes produtivos complexos, como job-shop e indústrias que operam com a política MTO, originário do conceito de controle entrada / saída. Neste, a carga de trabalho total admitida (entrada) nunca deve exceder à capacidade de executar as tarefas (saída); caso tal fato ocorra, há conseqüências, como conclusão atrasada das ordens e congestionamentos, entre outras, que tornam o processo ineficiente (CHASE et al., 2006).

No sistema WLC, os controle referentes às entradas estão relacionados aos estágios de consulta do cliente, entrada de pedidos e liberação de ordens para a fábrica. Uma vez liberadas, as ordens de trabalho são priorizadas e seqüenciadas, respeitando-se as regras de priorização (por exemplo, FIFO ${ }^{10}$ ). Estes estágios podem ser acompanhados por decisão relacionada ao controle de saídas no estágio de gerenciamento da capacidade (STEVENSON, 2006).

A Figura 8 sumariza a estrutura hierárquica de planejamento e controle do sistema WLC, indicando os estágios-chave do controle da produção.

${ }^{10}$ FIFO (acrônimo para First In, First Out, que em português significa "primeiro a entrar, primeiro a sair"). Processamento por ordem de chegada,ou seja, trata-se da idéia fundamental da fila, na qual só é possível inserir um novo elemento em seu final,assim como só é possível retirá-lo em seu início. 


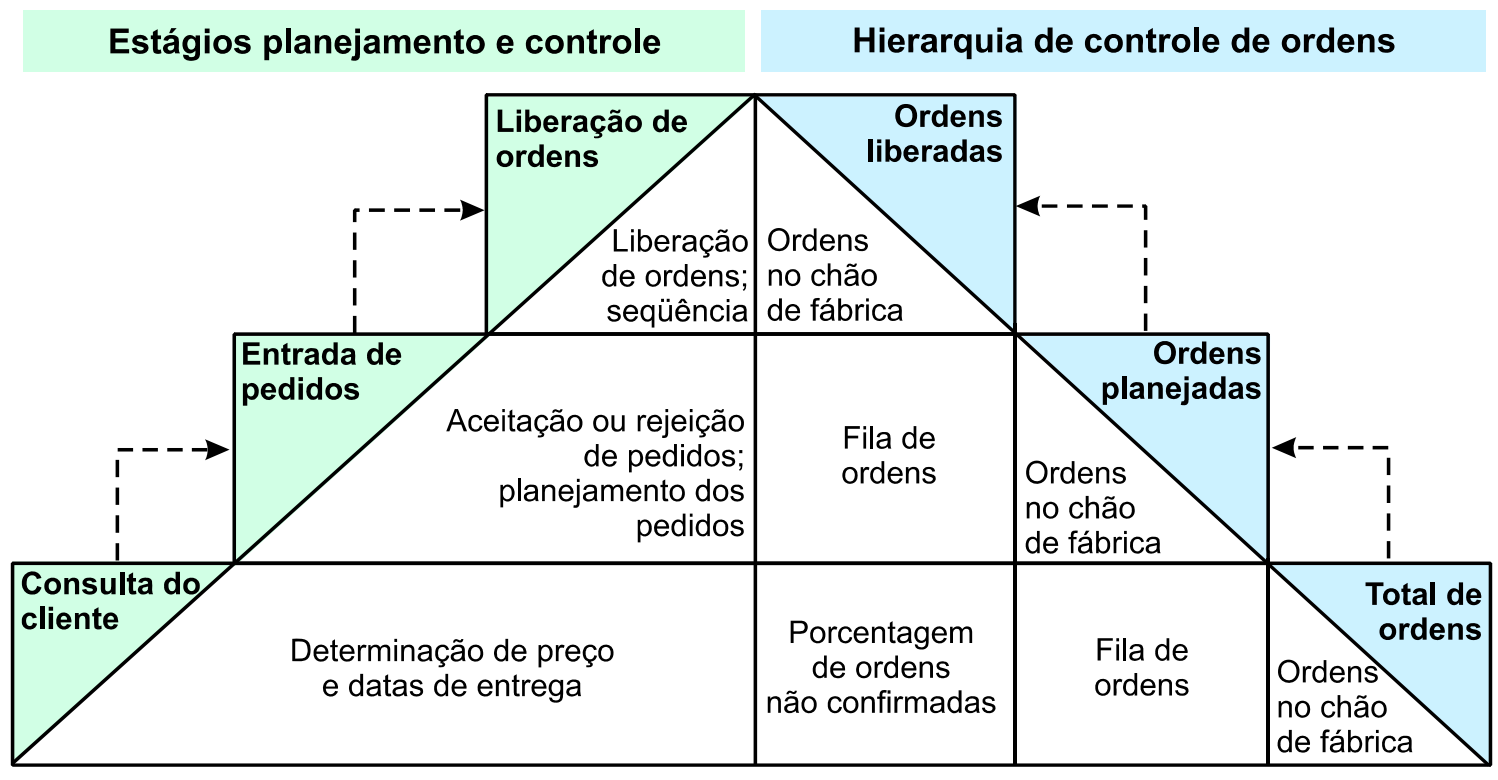

Fonte: Stevenson, (2006).

Figura 8 - Hierarquia de planejamento e controle da WLC

\section{Estágio de consulta do cliente}

Neste estágio, o cliente pode determinar o prazo de entrega ou simplesmente questionar o preço. O primeiro passo é verificar se este prazo pode ser atendido; considerando-o, utiliza-se a programação das atividades em uma seqüência reversa, ou seja, determinando quando deve ser lançado o pedido para alcançar a data específica. Caso a consulta requeira ambos, determinação de prazo de entrega e preço, logo o primeiro passo é calcular as possíveis alternativas de prazo (KINGSMAN, 2000).

As decisões tomadas neste estágio utilizam os tempos de filas nos recursos e os atrasos esperados para estimar o prazo de entrega; assim, somente o planejamento de capacidade a médio prazo é necessário até a confirmação do pedido (STEVENSON, 2006). 


\section{Estágio de entrada de pedidos}

Caso o cliente aceite a proposta, a empresa pode iniciar o plano de produção, finalizando os requisitos do processo, o que inclui os roteiros de trabalho e os materiais necessários. É possível, também, realizar o planejamento mais detalhado para a carga de trabalho e para a capacidade das máquinas a serem utilizadas (STEVENSON; HENDRY, 2006).

A entrada dos pedidos pode ocorrer imediatamente após a consulta do cliente, enquanto para os seguintes decorre um determinado período. Conseqüentemente, se o cliente aceita a proposta, será necessário reavaliar a data de entrega e assegurar que a empresa pode ainda alcançá-la (STEVENSON, 2006).

\section{Estágio de liberação de ordens}

Finalmente neste estágio a empresa deve decidir quando as ordens serão liberadas para o chão de fábrica, ocorrendo, conseqüentemente, o início de produção. Uma vez liberadas as ordens, serão consideradas work-in-process (WIP). A prioridade de liberação está relacionada ao caminho pelo qual as ordens são seqüenciadas nas máquinas, por exemplo respeitando-se a política do FIFO (STEVENSON; HENDRY, 2006).

\section{Gerenciamento da capacidade}

A mudança de capacidade dos recursos tem impacto em toda a hierarquia de ordens, influenciando o total de ordens, as planejadas e as liberadas. Três opções principais para modificar a taxa de saída são: 
1. operadores podem ser realocados de um recurso subutilizado para um sobrecarregado;

2. horas extras podem ser utilizadas por um ou mais recursos;

3. a empresa pode subcontratar parte ou o trabalho como um todo.

Toda ordem de trabalho na empresa, em qualquer estágio, para cada centro de trabalho, resulta no total de carga de trabalho (workload) que a empresa deve processar. Assim, o tempo de processo requerido para esta ordem, somado ao de consulta do cliente, resulta no tempo total de entrega para um novo pedido, caso este seja processado normalmente, sem qualquer prioridade ou alteração de capacidade já planejada para os períodos futuros (STEVENSON, 2006).

\subsubsection{Análise da adequação dos sistemas de PCP à política MTO}

Para realizar a análise da adequação dos sistemas de PCP à política MTO, vale ressaltar algumas importantes características deste ambiente. Segundo Vollmann et al. (2005), o ambiente MTO é caracterizado por uma larga variedade de produtos, tipicamente produzidos em baixos volumes e geralmente com projetos customizados. A aderência ao prazo de entrega é um grande desafio enfrentado pelas empresas que operam neste ambiente. Uma vez que o objetivo destas empresas envolve oferecer uma ampla variedade de competências operacionais, seu processo de manufatura freqüentemente suporta a produção de pequenos lotes de baixo volume (job-shop / lotes).

A Figura 9 relaciona os conceitos de PCP às características de produto, processo e políticas de atendimento da demanda (SILVER et al., 1998; VOLLMANN et al., 2005): 


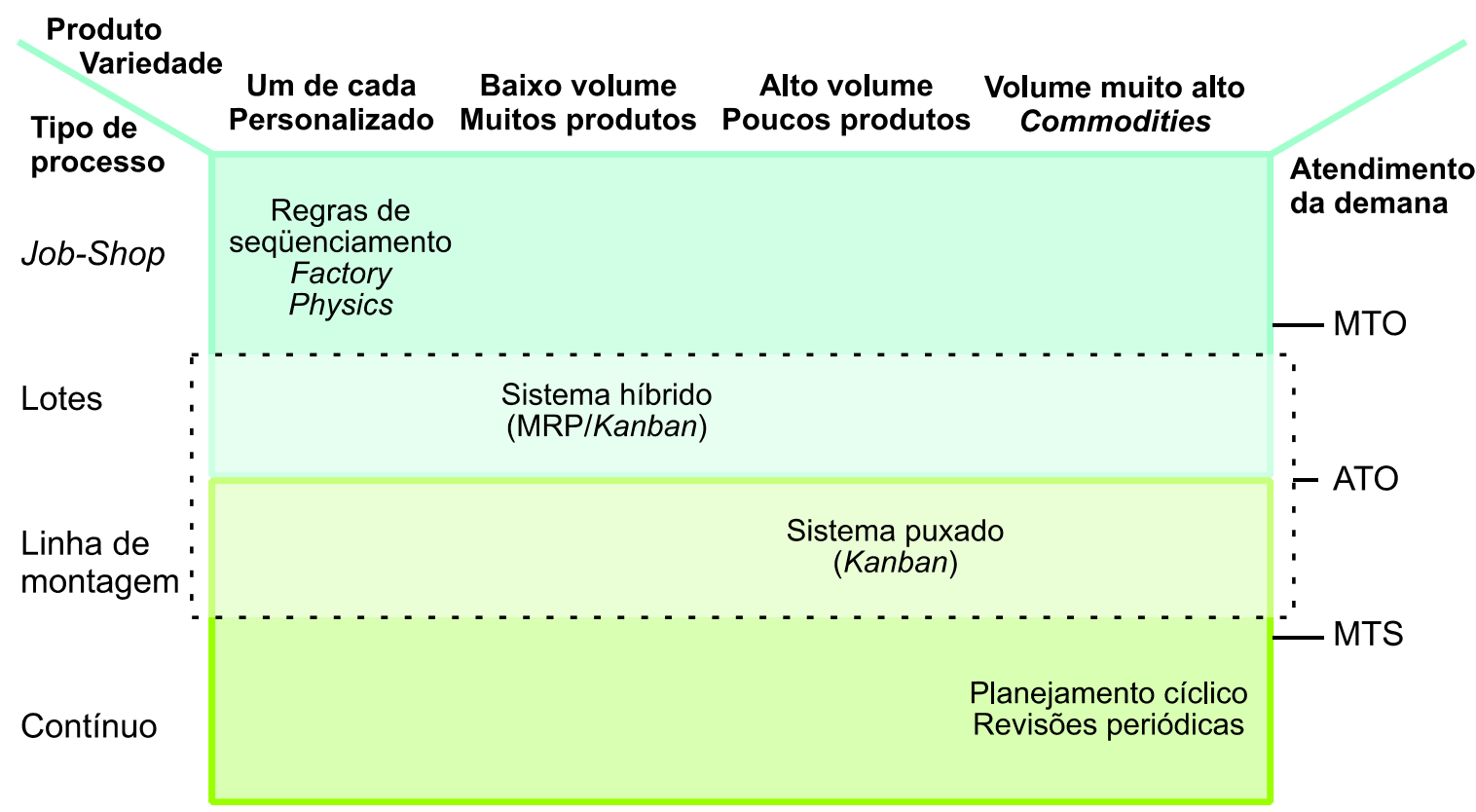

Fonte: adaptada de Silver et al., (1998).

Figura 9 - Relação de conceitos de PCP, produto, processo e atendimento da demanda

Conforme descrito anteriormente, o sistema híbrido possui uma série de vantagens sobre o sistema puxado tradicional, uma vez que possibilita o controle de uma variedade maior de itens, assim como a coordenação de pedidos de materiais e a programação de datas de entrega. Estas características são importantes para se operar no ambiente MTO e são encontradas nos quatro sistemas analisados (AFT, CONWIP, POLCA e WLC). Porém, caso o processo da empresa se aproxime de um ambiente job-shop, ou seja, programação incerta, mudanças freqüentes, dificuldade de estimar as necessidades, ampla utilização da mão-de-obra e estoques muito baixos, é necessário agregar outras características ao sistema de PCP.

Regras de seqüenciamento e factory physics (planejamento de capacidade, liberação de ordens, controle do chão de fábrica e gerenciamento do estoque) são características necessárias para o sistema de PCP de um job-shop. É exatamente esta parte da matriz que reflete o ambiente encontrado na maioria das pequenas e médias empresas operam com a política MTO. Henrich et al. (2004) sugerem que, dentre outros, o sistema WLC é particularmente adequado a este ambiente. 
Outra análise a ser realizada refere-se aos critérios de aplicabilidade das alternativas de PCP para o ambiente MTO propostas por Stevenson et al. (2005) e demonstradas na Figura 10:

\begin{tabular}{|l|c|c|c|c|}
\hline \multirow{2}{*}{ Critérios } & \multicolumn{4}{c|}{ Sistemas de PCP } \\
\cline { 2 - 6 } & AFT & CONWIP & POLCA & WLC \\
\hline Programação de datas de entrega & $\bigcirc$ & $\bigcirc$ & $\bigcirc$ & $\bigcirc$ \\
\hline Planejamento da capacidade & $\bigcirc$ & $\bigcirc$ & $\bigcirc$ & $\bigcirc$ \\
\hline Seqüenciamento e liberação de ordens & $\bigcirc$ & $\bigcirc$ & $\bigcirc$ & $\bigcirc$ \\
\hline Habilidade de lidar com produções não repetitivas & $\bigcirc$ & $\bigcirc$ & $\bigcirc$ & $\bigcirc$ \\
\hline Planejamento de roteiros de produção variáveis & $\bigcirc$ & $\bigcirc$ & $\bigcirc$ & $\bigcirc$ \\
\hline Aplicabilidade em pequenas e médias empresas & & & & $\bigcirc$ \\
\hline
\end{tabular}

Não atende ou necessita de customização

Atende parcialmente

Atende totalmente

Fonte: elaborada pelo autor.

Figura 10 - Avaliação da aplicabilidade das alternativas de PCP ao ambiente MTO

O sistema AFT é o sistema de Kanban interligado ao sistema MRP. Separadamente, o Kanban é um sistema de controle do chão de fábrica descentralizado e não possui um controle sobre os estágios de consulta do cliente, de entrada e de liberações de ordens. Associado ao MRP, o sistema pode acomodar o controle de uma larga variedade de produtos assim como a variabilidade da demanda; porém, para atender plenamente aos requisitos do ambiente MTO apresentados no item 2.4.1, o sistema necessitará de customização.

O sistema CONWIP é uma abordagem de maior aplicabilidade em ambientes MTO em relação ao sistema Kanban. Entretanto, é questionável se o sistema pode fornecer o controle necessário para os estágios de consulta do cliente, de entrada e de liberação de ordens. Adicionalmente, o sistema necessita que os produtos 
acabados sejam agrupados em famílias com rotas comuns, restringindo a possibilidade de customização.

A breve discussão sobre o sistema POLCA sugere alta aplicabilidade em ambientes MTO. Entretanto, é difícil tomar decisões conclusivas até que futuras pesquisas nesta área sejam conduzidas. Além disso, assim como em outros sistemas controlados por cartões, o sistema POLCA confia no suporte de níveis mais altos de planejamento para determinar datas de entrega, baseadas no carregamento e nas capacidades da manufatura durante o estágio de consulta do cliente. Similarmente, o sistema necessita operar conjugado a outros para incorporar os estágios de entrada de pedidos e de liberação de ordens.

O sistema WLC pode ser um efetivo método para reduzir WIP e controlar lead times, acomodando produções não repetitivas e com rotas variáveis. Há também a possibilidade de acomodar o estágio de consulta do cliente, considerando o total de ordens pendentes na manufatura para a determinação da data de entrega, assim como o planejamento da capacidade nos níveis mais baixos da entrada de pedidos e de liberação de ordens. Este conjunto de características o qualificam como o sistema de PCP mais apropriado para ambientes MTO. 


\section{Projeto da Pesquisa}

\section{CAPÍtulo 3}

\subsection{Metodologia}

Neste estudo optou-se pela pesquisa-ação. Segundo Coughlan e Coghlan (2002), muitas características a definem:

- Pesquisa em ação ao invés de pesquisa sobre a ação: a idéia central é utilizar uma abordagem científica para estudar a resolução de importantes questões sociais ou organizacionais em conjunto àqueles que vivenciam estas questões diretamente. A pesquisa-ação funciona por meio de um processo cíclico, cujos passos principais são: planejamento, implementação da ação e sua avaliação além da, caso necessária, condução de planos adicionais;

- Participativa: membros do sistema participam ativamente do ciclo descrito acima. Esta característica contrasta com a pesquisa tradicional na qual os membros do sistema são objetos do estudo;

- Simultaneamente com a ação: o objetivo é implementar uma ação efetiva enquanto é construído o conhecimento científico;

- Seqüência de eventos e abordagem de solução de problemas: como uma seqüência de eventos, compreende o ciclo de coleta, registro e análise de dados, planejamento das ações, sua implementação e avaliação, além da condução de planos adicionais. Por configurar-se como abordagem de solução de problemas, trata-se da aplicação de um método científico de busca e experimentação de problemas práticos que demandam soluções, porém envolvendo tanto a colaboração como a cooperação do pesquisador e de membros da empresa. 
Os resultados desejados da metodologia pesquisa-ação não estão relacionados somente à solução de problemas imediatos, mas também a importantes ensinamentos a partir dos resultados, pretendidos ou não, além da contribuição para o conhecimento científico.

A escolha da empresa objeto de estudo foi baseada em sua representatividade no setor, sendo uma das maiores prestadoras de serviços de manufatura. Dada a natureza dos produtos e o tipo de relacionamento com cliente, trata-se de um caso puro de adoção da política MTO.

A implementação da pesquisa-ação foi delineada pelas seguintes etapas, conforme ilustração na Figura 11:

1. contextual: entendimento do contexto e proposta da pesquisa;

2. ciclo da pesquisa: coleta de dados, sua documentação e análise, planejamento, implementação e avaliação das ações;

3. monitoramento.

Contexto e proposta da pesquisa

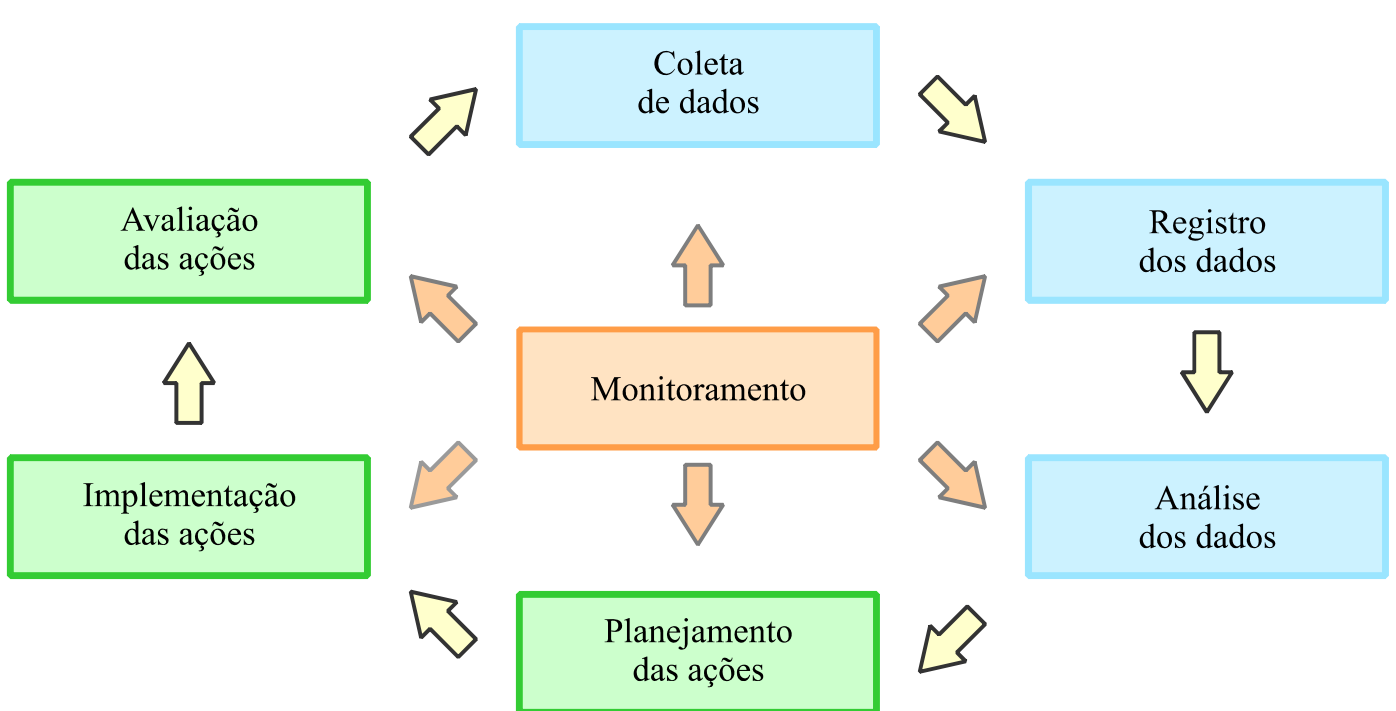

Fonte: Coughlan e Coghlan, (2002).

Figura 11 - Etapas da pesquisa-ação 


\subsection{Proposições da pesquisa}

A revisão teórica discutida anteriormente direciona as seguintes proposições:

P1: A adoção de práticas do sistema $L M$ auxilia as empresas que operam em ambientes MTO a desenvolverem competências operacionais alinhadas aos requisitos do mercado.

P2: A seleção e implementação de práticas do sistema $L M$ são baseadas em contextos específicos que incluem tanto fatores externos como internos da empresa.

P3: O sistema WLC é mais eficaz que o MRP tradicional, em ambiente MTO, pois melhora a definição de prazos junto ao cliente, o gerenciamento da capacidade e o seqüenciamento das ordens na produção.

\subsection{Objeto de estudo}

O objeto de estudo é uma empresa de médio porte, empregando 200 funcionários; atua no setor de higiene pessoal, perfumaria e cosméticos como prestadora de serviço de manufatura. A sua carteira de clientes é composta por mais de 300 clientes, incluindo as grandes empresas do setor.

A empresa gerencia aproximadamente 2.600 produtos distintos com diferentes características de produtos e embalagens. A empresa não possui produtos de fabricação própria, logo suas instalações e processos foram projetados para atender às diversas especificações dos clientes.

A análise da estrutura e da infra-estrutura da empresa é descrita a seguir: 
a. Capacidade de produção: a empresa possui uma capacidade produtiva média de 2.000.000 de unidades/mês, operando em dois turnos de produção. A expansão da capacidade produtiva pode ser rapidamente obtida por meio da utilização de horas extras ou da contratação de mão-de-obra temporária.

b. Instalações: o arranjo físico é composto pelas áreas de armazenagem, pesagem, fabricação e enchimento, e embalagem. O arranjo físico e o fluxo de materiais são ilustrados na Figura 12:

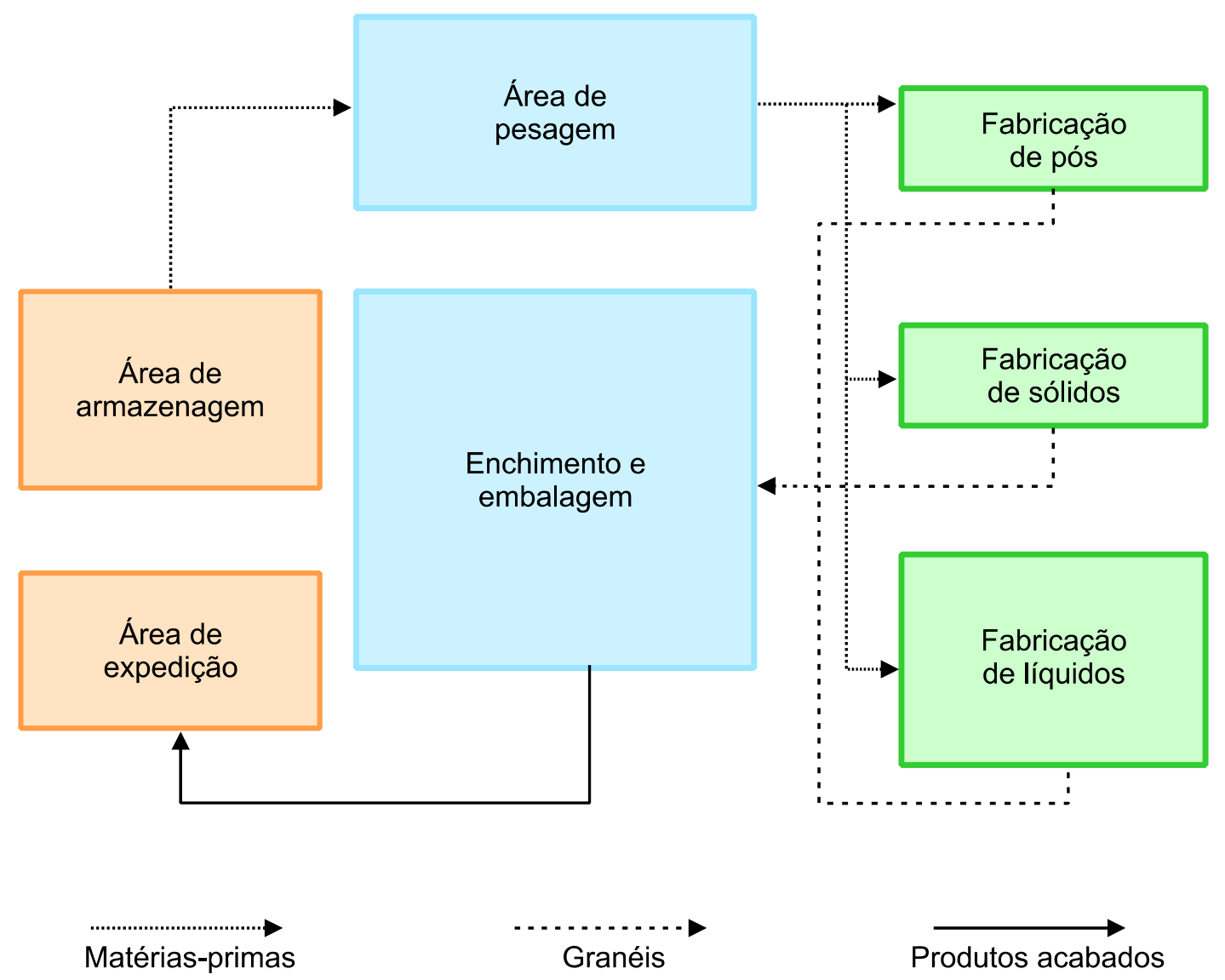

Fonte: elaborada pelo autor.

Figura 12 - Arranjo físico macro e fluxo de materiais 
- Armazenagem: área destinada à guarda segura e ordenada de matérias-primas ${ }^{11}$, granéis ${ }^{12}$ e embalagens. A área reúne as funções de recebimento, identificação e classificação dos materiais, conferência (quantitativa e qualitativa), endereçamento ao estoque, separação de matérias-primas e embalagens para o atendimento das ordens de produção, além da expedição.

o Pesagem: área na qual as matérias-primas são quantificadas e identificadas conforme a fórmula do produto a ser fabricado. As atividades são realizadas em balanças de alta precisão e salas especialmente desenvolvidas para evitar a contaminação cruzada.

o Fabricação: área destinada à elaboração ${ }^{13}$ dos produtos; é composta por seis equipamentos utilizados na fabricação de líquidos, quatro para sólidos e um para pós.

o Enchimento e embalagem ${ }^{14}$ : área composta por dezessete linhas, sendo oito destinadas ao enchimento de líquidos, cinco à embalagem de sólidos, três à montagem de conjuntos e ao enchimento de pós.

c. Força de trabalho: composta por 160 operadores divididos em auxiliares e operadores de enchimento e embalagem, fabricação, pesagem e sanitização.

d. Gerenciamento do fluxo de materiais: realizado por um sistema MRP, o qual desempenha as funções de requisição e separação de materiais, além da liberação de ordens para a produção.

\footnotetext{
${ }^{11}$ Matérias-primas: qualquer substância envolvida na obtenção de um produto a granel que faça parte deste na sua forma original ou modificada.

${ }^{12}$ Granéis (produto a granel): produto que sofreu todas as etapas da fabricação, à exceção do enchimento e embalagem.

${ }^{13}$ Elaboração: operação que permite que matérias-primas preparadas através de um processo definido resultem na obtenção de um produto a granel.

${ }^{14}$ Enchimento e embalagem: conjunto de operações pelas quais, a partir do produto a granel e do material de embalagem (incluindo o rótulo), chega-se a um produto final.
} 
e. Organização: a estrutura hierárquica da manufatura é ilustrada na Figura 13:

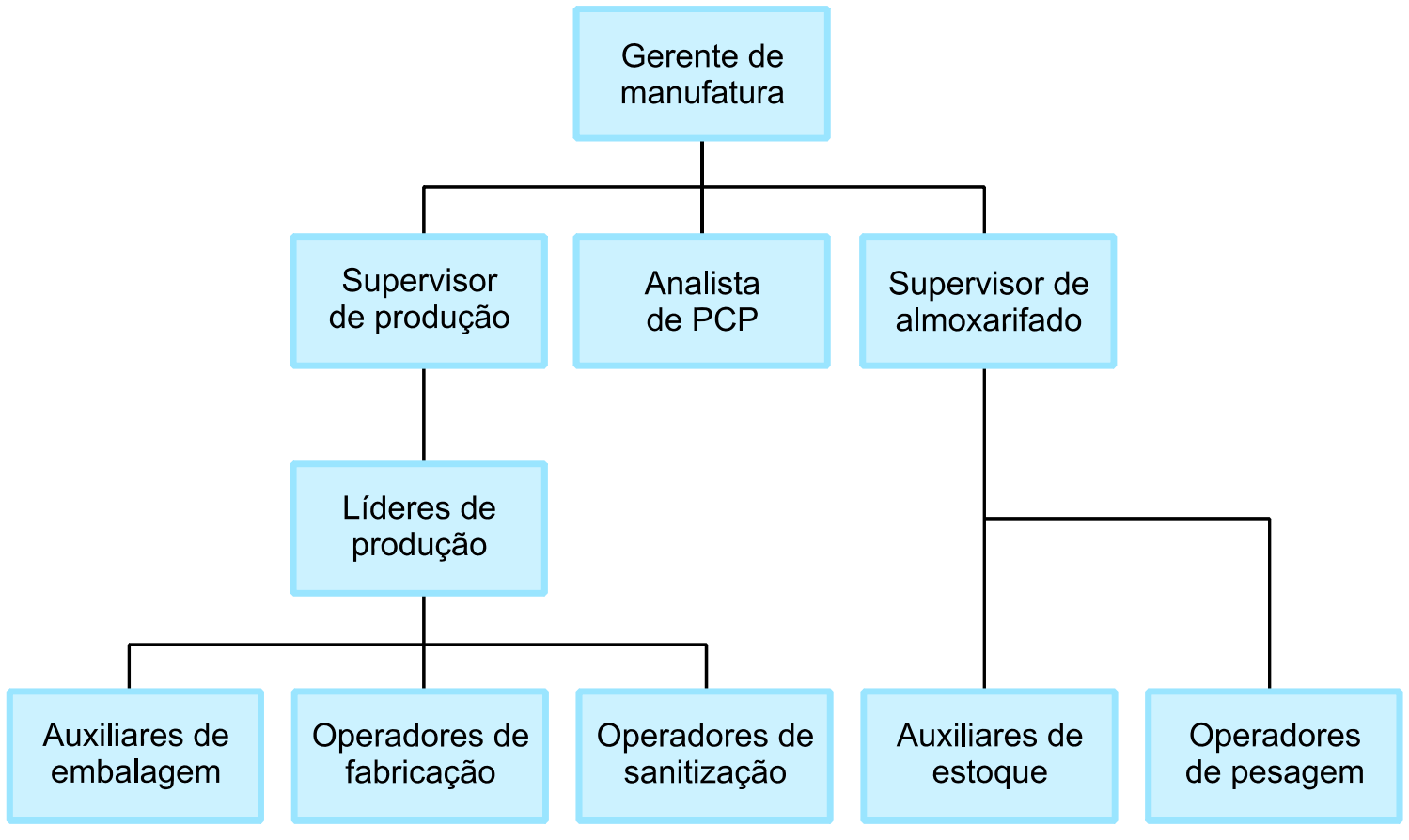

Fonte: elaborada pelo autor.

Figura 13 - Estrutura hierárquica da manufatura

f. Medidas de desempenho: devido aos altos padrões de qualidade exigida pelo mercado, a empresa focava seus indicadores de desempenho unicamente nesta dimensão.

A empresa presta três tipos de serviços, os quais determinam os processos envolvidos. Estes são diferenciados pelo grau de envolvimento do cliente na aquisição de matérias-primas e embalagens, além da fabricação de granéis. São eles:

1. Full service: neste serviço, após o desenvolvimento do produto em conjunto com o cliente, a empresa é responsável pela aquisição de matérias-primas e embalagens, fabricação, enchimento e embalagem de acordo com os pedidos.

2. Fabricação, enchimento e embalagem: neste serviço, o cliente se responsabiliza pela aquisição de matérias-primas e embalagens, sendo 
a fabricação, o enchimento e a embalagem de responsabilidade da empresa.

3. Enchimento e embalagem: neste serviço, a empresa é responsável somente por estas etapas, sendo que a fabricação de produtos a granel e o fornecimento das embalagens são atividades desenvolvidas pelo cliente.

Estes tipos de serviço irão determinar o fluxo do processo bem como o tempo de atendimento aos pedidos (conforme Figura 14).

\begin{tabular}{|c|c|c|c|c|}
\hline $\begin{array}{l}\text { Tipos de serviços } \\
\text { prestados }\end{array}$ & $\begin{array}{l}\text { Compra de } \\
\text { materiais }\end{array}$ & Fabricação & $\begin{array}{l}\text { Enchimento } \\
\text { e embalagem }\end{array}$ & Entrega \\
\hline Full service & CODP & & & \\
\hline $\begin{array}{l}\text { Fabricação, enchimento } \\
\text { e embalagem }\end{array}$ & CODP $----\rightarrow$ & & & \\
\hline Enchimento e embalagem & CODP - - - - & ------- & 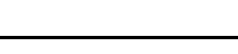 & . \\
\hline
\end{tabular}

$------\rightarrow$ Atividades realizadas pelo cliente

$\longrightarrow$ Atividades realizadas pelo prestador de serviço

Fonte: elaborada pelo autor

Figura 14 - Tipos de serviços prestados

\subsection{Contexto e proposta da pesquisa}

A Tabela 6 fornece um roteiro de referência para a discussão e 0 desenvolvimento do projeto de pesquisa relacionando o processo de pesquisa-ação aos conceitos abordados na revisão da literatura. 
Tabela 6 - Roteiro de referência para a discussão e o desenvolvimento do projeto de pesquisa

\begin{tabular}{lll}
\hline Etapas da Pesquisa-ação & \multicolumn{1}{c}{ Formulação da estratégia } & \multicolumn{1}{c}{ Sistema LM } \\
\hline $\begin{array}{l}\text { Contexto e proposta da } \\
\text { pesquisa }\end{array}$ & Definir os objetivos da empresa & $\begin{array}{l}\text { Pré-requisitos para a } \\
\text { implementação }\end{array}$ \\
$\begin{array}{l}\text { Coleta e } \\
\text { documentação dos dados }\end{array}$ & $\begin{array}{l}\text { Selecionar famílias de produtos } \\
\text { Avaliar condições externas } \\
\text { Avaliar as competências internas } \\
\text { Analisar as lacunas existentes } \\
\text { Análise dos dados }\end{array}$ & $\begin{array}{l}\text { Coleta de dados } \\
\text { desejado }\end{array}$ \\
Planejamélise do problema \\
Implemento das ações & $\begin{array}{l}\text { Priorizar as questões-chave e } \\
\text { definir os objetivos da manufatura }\end{array}$ & Implementação das soluções \\
Avaliação das ações & Definir a estratégia da manufatura & Implementação das soluções \\
\hline
\end{tabular}

Fonte: elaborada pelo autor.

Analisando-se o contexto e proposta da pesquisa, a primeira questão a ser respondida é:

- Qual foi a razão para a implementação de mudanças na empresa?

Segundo Souza e Voss (2007), as empresas de manufatura contratada são submetidas a uma forte influência das empresas contratantes em vários níveis de decisão, os quais são constantemente desequilibrados em favor do cliente. No caso da empresa objeto do estudo, estas influências eram visíveis na definição de prazos de entrega e na necessidade freqüente de alterações de datas de entrega.

As dificuldades de gerenciar os pedidos dos clientes, a capacidade produtiva e, conseqüentemente, de cumprir os prazos de entrega estabelecidos foram os principais motivadores para a implementação de mudanças na empresa. Tais alterações envolveriam a revisão da estratégia pretendendo desenvolver competências operacionais que possibilitassem suportar os objetivos da manufatura e, em conseqüência, atender aos requisitos do mercado. 
Conforme ressalta Hirano (1998), toda mudança encontra resistência; logo era fundamental o envolvimento das pessoas neste processo, assim como a necessidade de que políticas e princípios fossem mantidos claros.

A segunda questão a ser respondida é:

- Qual a razão para a pesquisa?

De acordo com o mencionado anteriormente, o desenvolvimento de competências operacionais alinhadas aos requisitos do mercado é um fator crítico de sucesso das empresas. Aquelas que operam em ambientes MTO são pequenas e médias, com recursos financeiros limitados, tornando-as, portanto, particularmente suscetíveis às conseqüências de uma implantação fracassada da estratégia. A metodologia de pesquisa-ação por intermédio da abordagem de solução de problema utiliza a busca e experimentação de problemas práticos, objetivando, além da resolução, uma contribuição para o conhecimento. 


\section{Etapas da Pesquisa}

Capítulo 4

\subsection{Coleta e registro de dados}

A coleta e o registro de dados constituem uma das etapas mais importantes do processo de revisão da estratégia. Por intermédio desta, é possível identificar a situação atual da empresa em relação às suas competências, aos objetivos e onde se encontram as principais oportunidades de melhoria.

Conforme apresentado anteriormente, os requisitos do cliente enfatizavam a importância da dimensão entrega (aderência aos prazos de entrega e entregas rápidas) estabelecendo, desta forma, as prioridades competitivas da empresa. Internamente, a dimensão custo era afetada pelas ineficiências geradas a partir da dificuldade de atender aos requisitos do cliente. Pretendendo identificar as principais oportunidades de melhoria, um conjunto de indicadores foi selecionado para análise:

- entrega: aderência ao prazo de entrega (razão entre os pedidos entregues no prazo e o total de faturados) e tempo de ciclo do pedido (somatória dos tempos decorridos desde a aceitação do pedido até a entrega ao cliente);

- custo: eficiência da manufatura (razão entre a produção real e a capacidade efetiva);

O critério de escolha dos indicadores foi baseado nas recomendações de Tangen (2005); de acordo com o autor, os indicadores devem ser compreendidos integralmente por todos os envolvidos, além de apresentarem fácil mensuração e dados precisos. 
Para isso, foram realizados treinamentos com todas as pessoas envolvidas no processo de coleta e registro de dados, visando ao alinhamento de conceitos e à conscientização quanto à importância desta etapa do processo. Concomitantemente, foram realizadas modificações no sistema ERP a fim de facilitar a coleta e o registro de tais informações.

$\mathrm{Na}$ tentativa de captar integralmente a ocorrência de eventos relacionados ao efeito sazonal dos pedidos, às mudanças de produtos (set-ups), às paradas não planejadas de máquinas e à falta de operadores, entre outros - fatos que auxiliariam durante a etapa de análise dos dados - optou-se pelo período de um mês para coletar e registrar os dados. Os resultados de cada indicador são demonstrados nos Gráficos 1, 2 e 3:

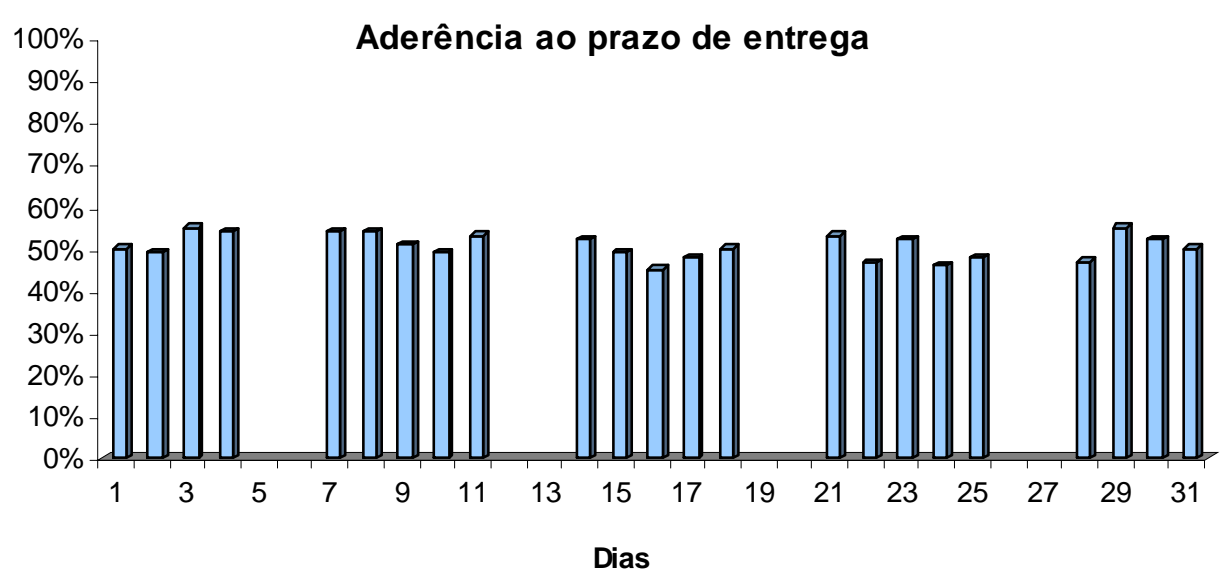

Fonte: elaborado pelo autor.

Gráfico 1 - Aderência ao prazo de entrega 


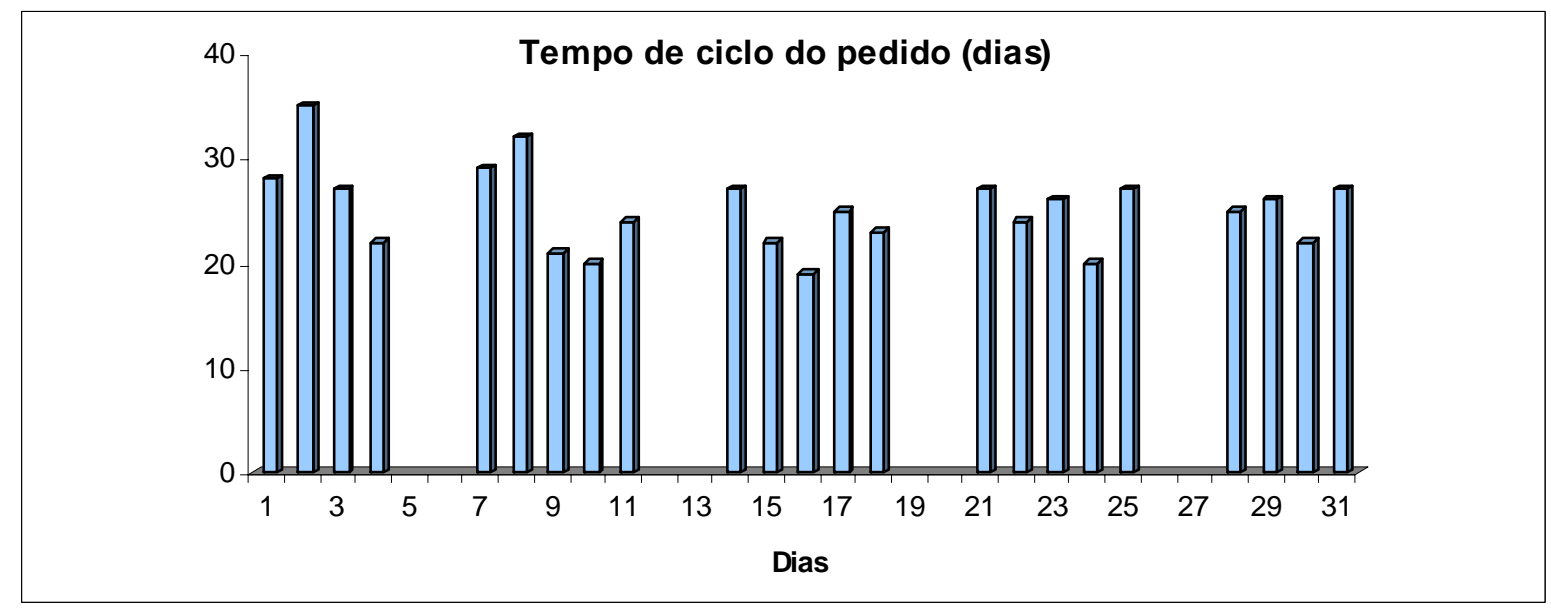

Fonte: elaborado pelo autor.

Gráfico 2 - Tempo de ciclo do pedido

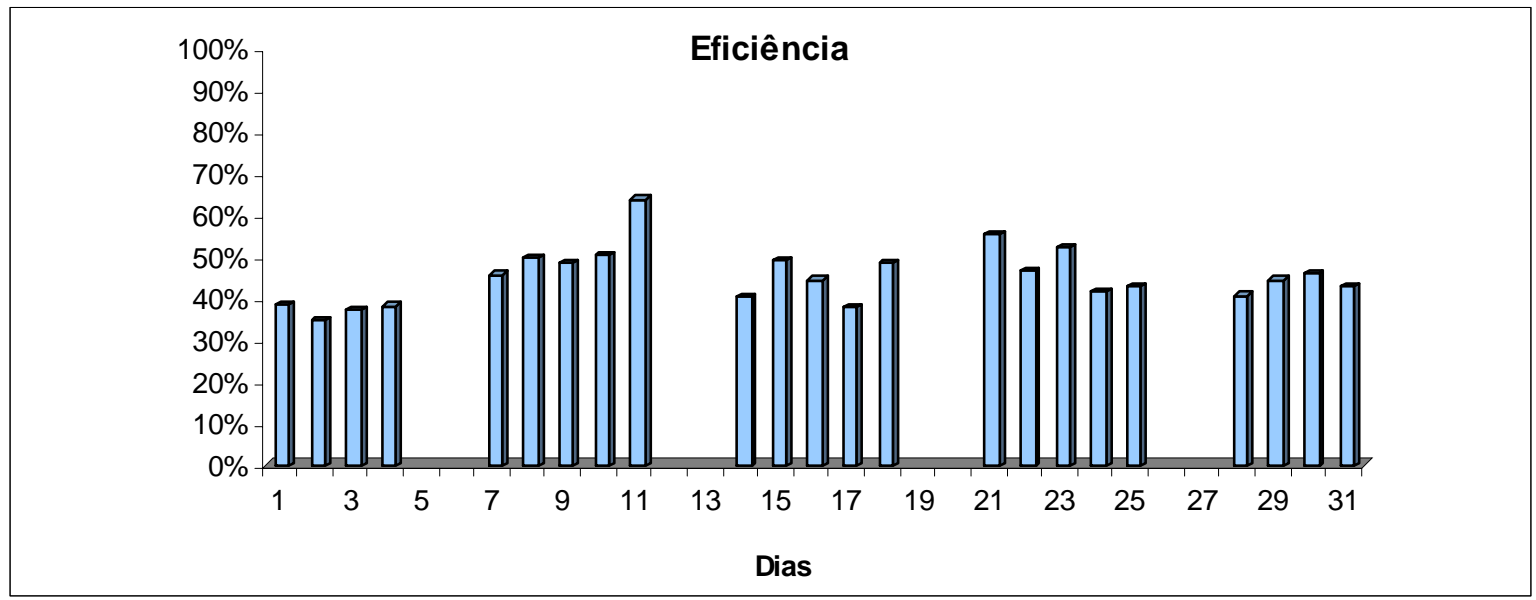

Fonte: elaborado pelo autor.

Gráfico 3 - Eficiência da manufatura

O sistema de coleta e registro de dados permitiu também que as principais perdas de eficiência fossem medidas e classificadas, conforme demonstrado no Gráfico 4: 


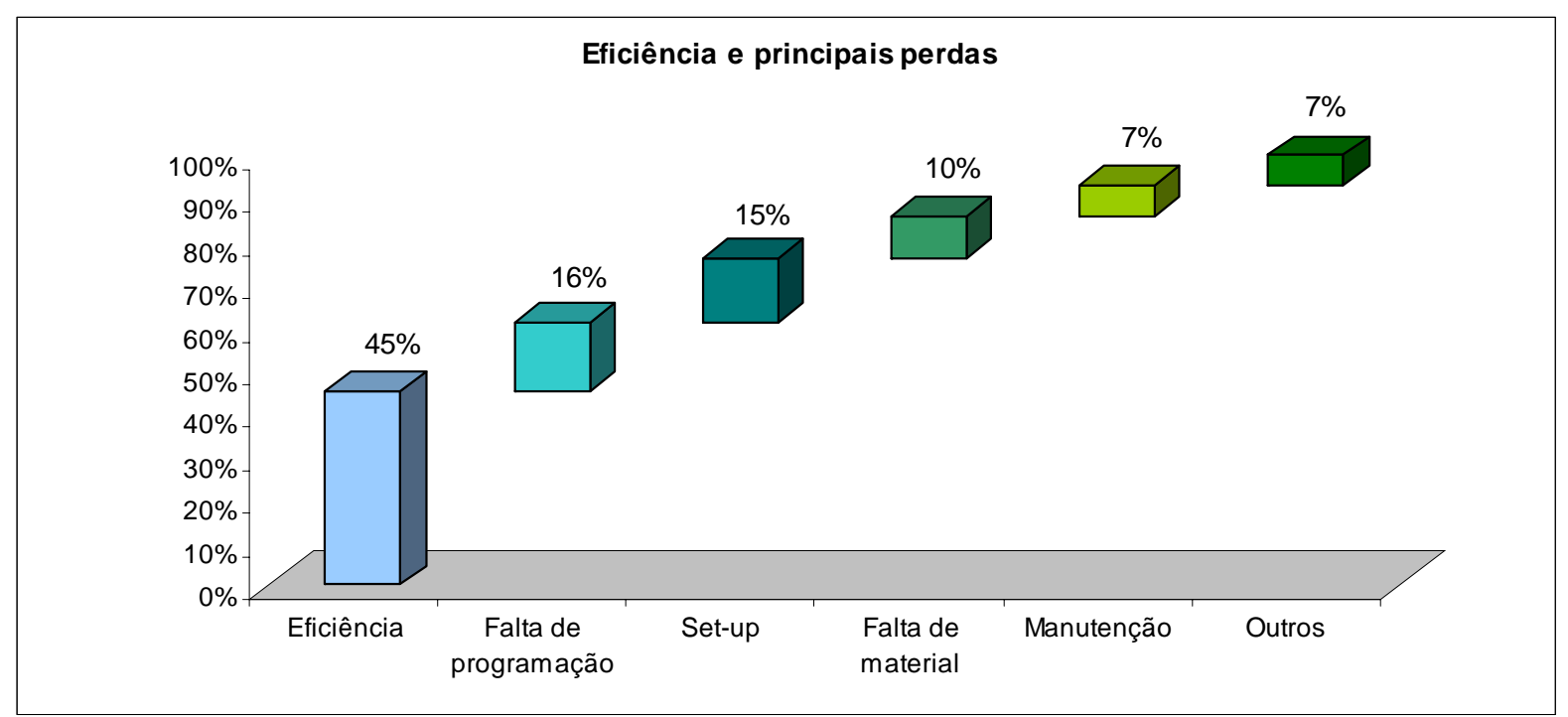

Fonte: elaborado pelo autor.

Gráfico 4 - Eficiência da manufatura e principais perdas

\subsection{Análise dos dados}

O aspecto crítico da etapa de análise na pesquisa-ação é o colaborativo, ou seja, pesquisador e membros da empresa devem realizá-la em conjunto. Os critérios e ferramentas de análise foram definidos de acordo com as necessidades do estudo e estão diretamente relacionados aos objetivos das intervenções.

Tan e Platts (2004) sugerem que, nesta etapa, a análise dos dados seja realizada tendo em vista a avaliação de quais competências operacionais devem ser adequadas para atender aos critérios competitivos da empresa. O resultado desta análise deve transformar as lacunas encontradas em um conjunto de prioridade e objetivos tangíveis.

Embora a empresa não possuísse os padrões de desempenho da concorrência para compará-los com o desempenho obtido, os indicadores de aderência ao prazo de entrega e de eficiência não eram vistos como razoáveis. 
Em média, apenas 50\% dos pedidos eram entregues no prazo, ocasionando freqüentes conflitos internos entre as áreas de Vendas e Manufatura, além da falta de credibilidade da empresa perante os clientes.

A medição das principais perdas de eficiência demonstrou ao grupo que obter uma eficiência média de 45\% não poderia ser visto como um desempenho aceitável, uma vez que a grande maioria das perdas era de natureza evitável.

Quanto ao tempo médio de ciclo do pedido - 25 dias (Gráfico 2) - entendeuse que uma redução acarretaria um grande diferencial competitivo e incentivaria a entrada de novos pedidos no estágio de Consulta do Cliente.

Portanto, ficou evidente para o grupo que as competências operacionais a serem desenvolvidas na manufatura deveriam resultar na habilidade de fornecer entregas mais rápidas e assegurar a aderência aos prazos.

No intuito de realizar uma análise detalhada das possíveis causas do baixo desempenho nos indicadores e estabelecer um plano de ação mais efetivo, foi utilizada a abordagem "causa-efeito" (dividida nas seguintes categorias: materiais, máquinas, métodos e mão-de-obra (MOD)). Um grupo multifuncional foi formado com funcionários das área de Manufatura, Manutenção, Vendas, Compras e Recursos Humanos, permitindo uma análise multifuncional acerca da inter-relação dos indicadores.

Os resultados dos diagramas causa-efeito são demonstrados nas Figuras 15, 16 e $17:$ 


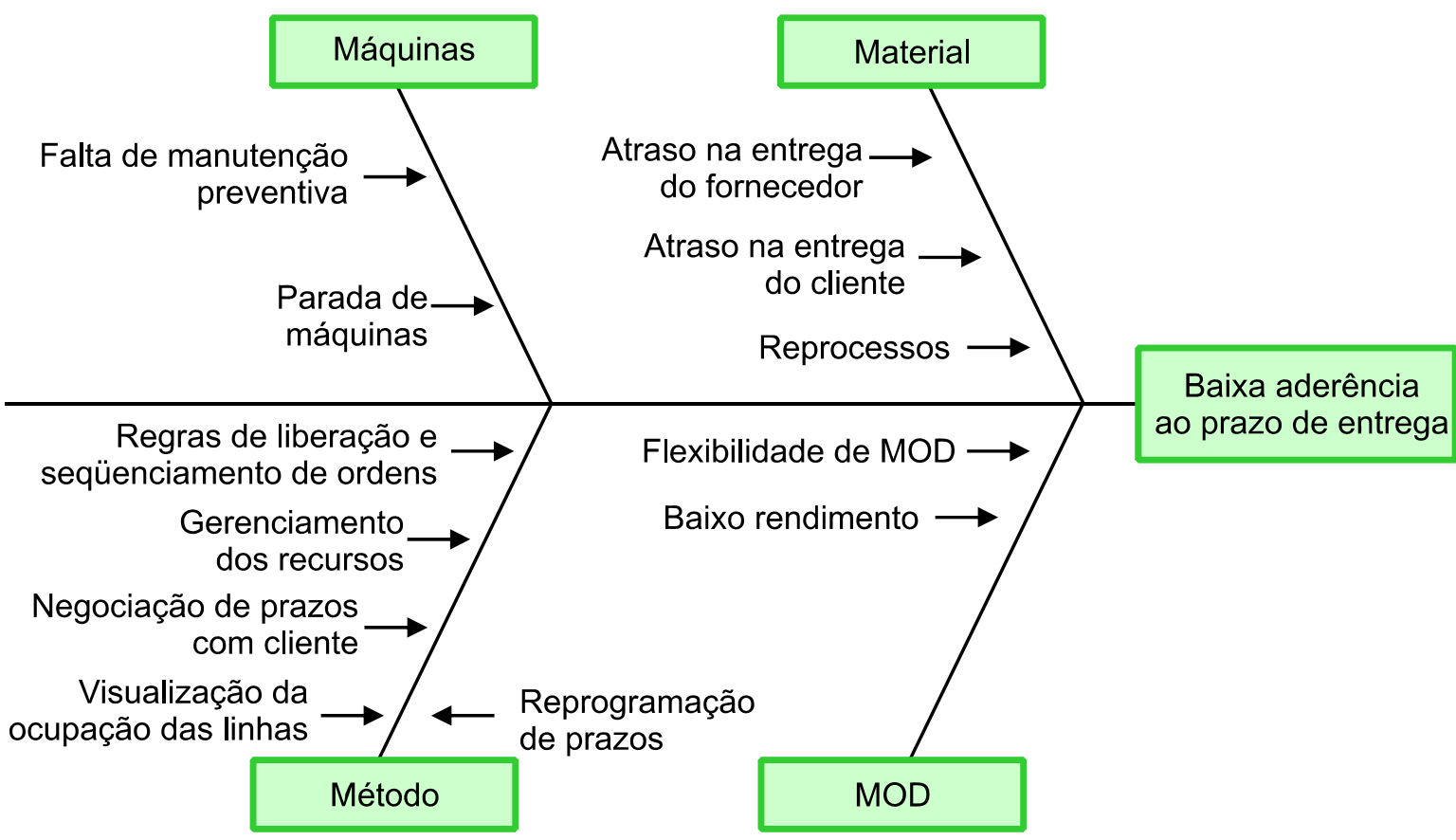

Fonte: elaborada pelo autor.

Figura 15 - Diagrama causa-efeito (aderência ao prazo de entrega)

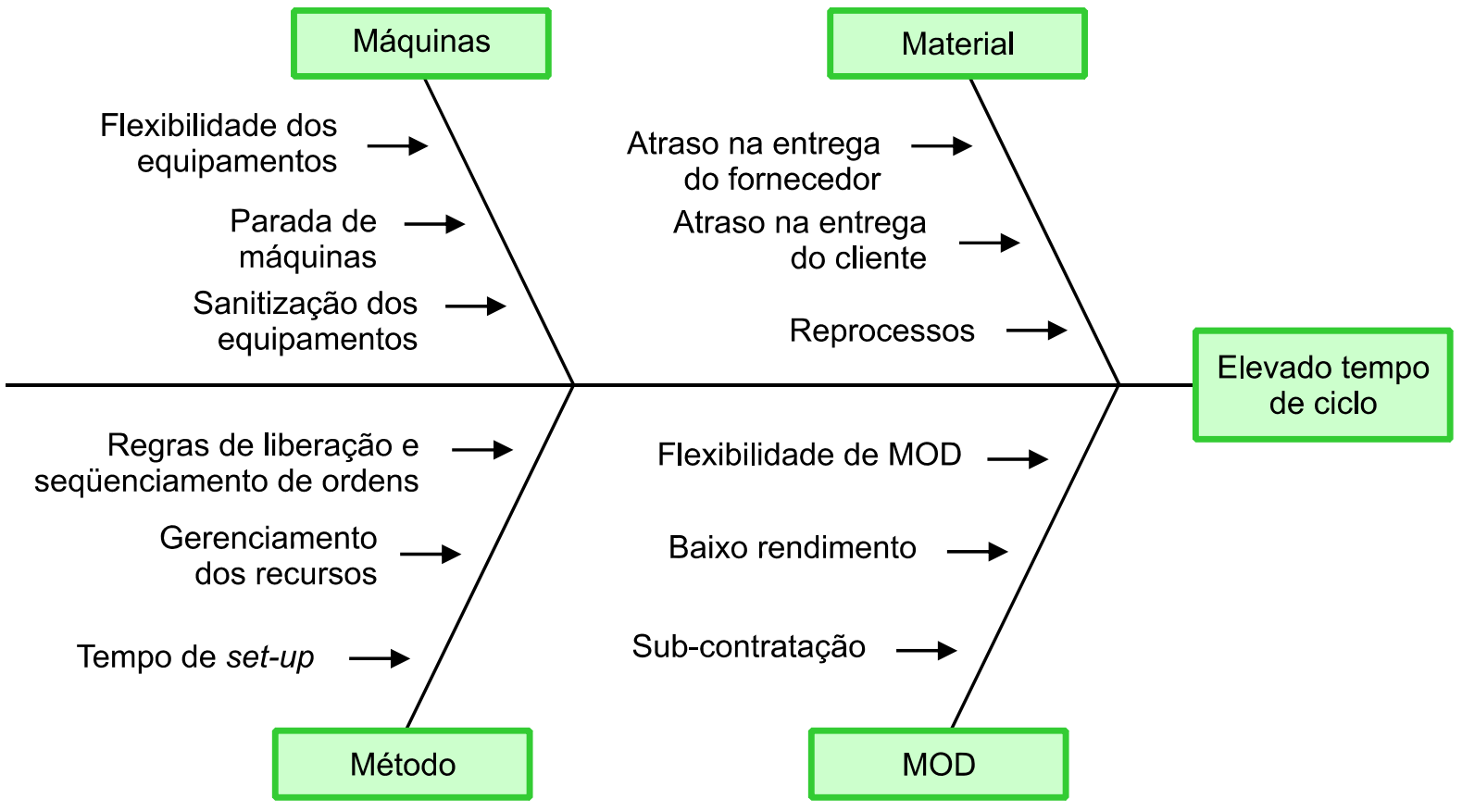

Fonte: elaborada pelo autor.

Figura 16 - Diagrama causa-efeito (tempo de ciclo do pedido) 


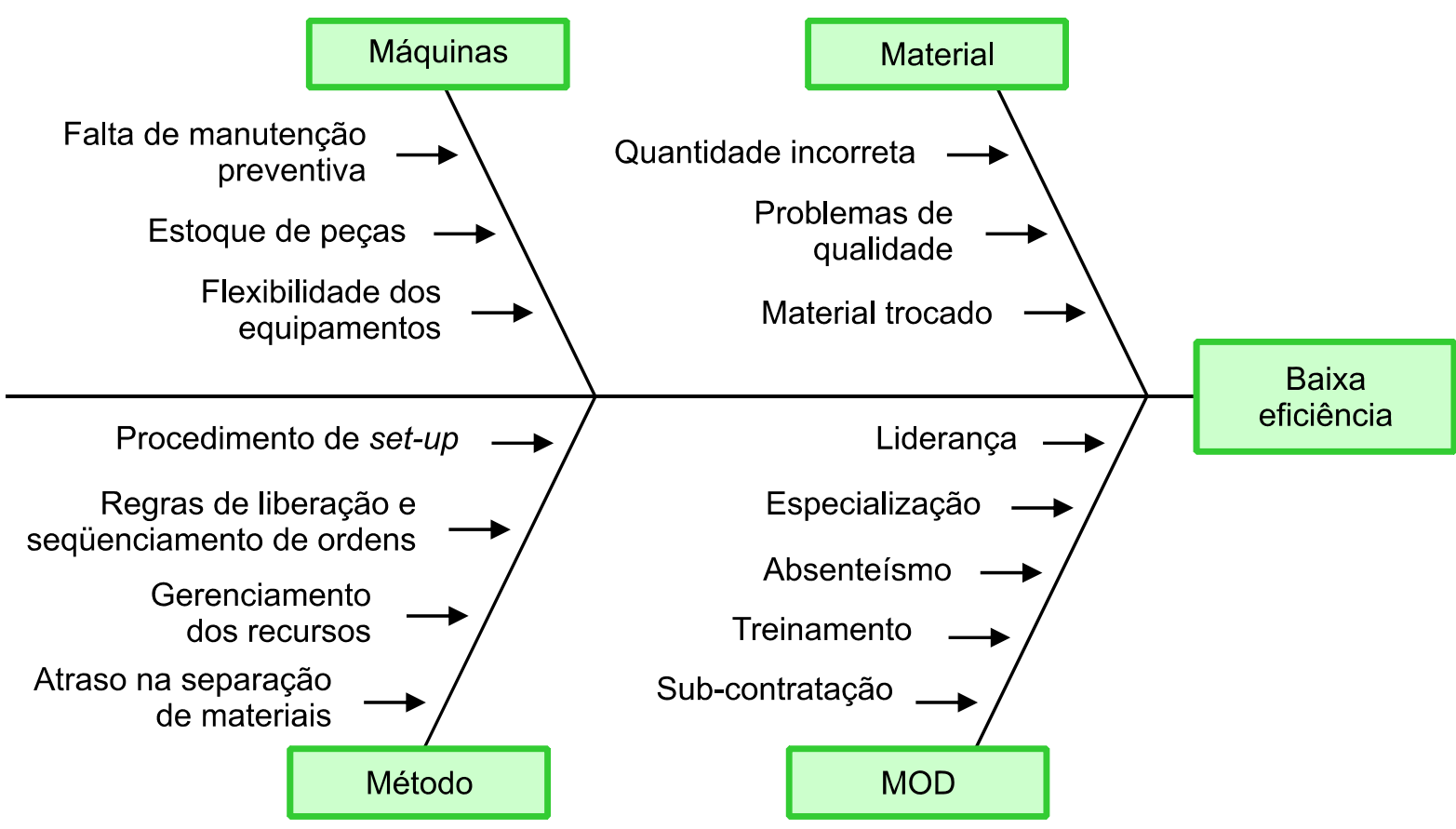

Fonte: elaborada pelo autor.

Figura 17 - Diagrama causa-efeito (eficiência da manufatura)

A análise das possíveis causas do baixo desempenho nos diversos indicadores revelou a presença de causas comuns e uma relação de dependência entre indicadores, conforme apresentado a seguir.

Na categoria mão-de-obra, a falta de flexibilidade da MOD foi citada como uma importante causa em todos os indicadores. Segundo o grupo, as características das linhas de enchimento e embalagem de pós, sólidos e líquidos exigiam diferentes habilidades de cada operador. A movimentação dos operadores, tanto entre as linhas quanto entre as operações de uma mesma linha, não era incentivada pelos líderes de produção. A falta de mobilidade gerou, de certa forma, a "especialização" dos operadores e, como conseqüência, a perda da habilidade de ajustar rapidamente a capacidade produtiva. Pelos mesmos motivos, os operadores de sanitização, responsáveis pela operação de set-up, detinham o conhecimento de máquinas específicas, limitando, conseqüentemente, as suas intervenções em todas as linhas. 
$\mathrm{Na}$ categoria materiais, o atraso nas entregas de materiais foi considerado a causa mais relevante para o impacto nos indicadores de desempenho. Tal problema pode ser gerado pelos fornecedores, no caso do full service, ou mesmo pelos clientes, no caso do serviço de fabricação, enchimento e embalagem. Visto que o sistema de gerenciamento de fornecedores apresentava falhas referentes ao follow$u p^{15}$ das entrega e ao cadastro do tempo de entrega, não era possível determinar o grau de responsabilidade dos fornecedores no processo. No caso dos materiais fornecidos por clientes, a falta de um entendimento prévio durante a fase de consulta destes sobre a capacidade da manufatura, ou seja, os tempos de filas nos recursos e atrasos estimados, ocasionava a determinação de prazos de entrega não-realistas e, conseqüentemente, seu não-atendimento.

A falta de flexibilidade dos equipamentos e as suas constantes paradas foram as causas mais relevantes, na categoria máquinas, para o explicar os baixos níveis de desempenho nos diversos indicadores. Um ponto importante para as empresas que operam em ambientes MTO com uma alta variedade de produtos relaciona-se ao fato de os equipamentos serem, necessariamente, simples e flexíveis para que os produtos possam ser fabricados de acordo com as especificações do cliente.

Finalmente, na categoria métodos foram considerados como causas principais os problemas de negociação de prazos com clientes, de gerenciamento dos recursos e do seqüenciamento de ordens de trabalho na manufatura - vale ressaltar que todos estes pontos estão relacionados ao sistema de PCP da empresa. Segundo a equipe de vendas, integrante do grupo de pesquisa, existia uma grande dificuldade de negociar prazos com os clientes devido à falta de visão dela própria sobre a capacidade da manufatura. De forma semelhante, a equipe de manufatura apontou que a falta de uma ferramenta que auxiliasse no gerenciamento dos recursos produtivos e ordenasse o fluxo das ordens na manufatura dificultava 0 entendimento da real capacidade da manufatura.

15 Follow-up: termo em inglês que significa saber mais sobre algo, ou tomar outras medidas relacionadas ao assunto. 


\subsection{Planejamento das ações}

Conforme o roteiro de referência apresentado na Tabela 6, esta etapa envolve a discussão das principais oportunidades de melhoria, o delineamento das alternativas, a definição dos critérios de seleção dos projetos, assim como o desenvolvimento das soluções.

A principais questões a serem respondidas nesta etapa são:

- O que necessita mudar?

- Quais são as ações?

- Em qual área da empresa?

- Que suporte é necessário?

- Como conseguir o comprometimento das pessoas?

- Como gerenciar as resistências?

De acordo com o descrito anteriormente, o principal objetivo para empresas que operam com a política MTO é cumprir os prazos de entrega. Para isto, devemse desenvolver competências operacionais para suportar este objetivo, ou seja, a habilidade de fornecer entregas rápidas, assim como assegurar a aderência aos prazos de entrega e reduzir o tempo de produção. Além disto, é necessário desenvolver uma operação flexível, capaz de manter a operação dentro do programado quando eventos imprevistos perturbam os planos (SLACK et al., 2002).

Como resultado da etapa de análise de dados, foram identificadas as seguintes oportunidades de melhoria que afetavam diretamente os desempenhos de entrega:

- aumento da flexibilidade da MOD;

- melhoria na gestão de fornecimento; 
- aumento da flexibilidade dos equipamentos;

- redução das paradas em equipamentos;

- redução do tempo de set-up;

- reavaliação do sistema de PCP.

A definição das ações de melhoria teve como base a busca na literatura de práticas de manufatura que pudessem auxiliar no processo de melhoria. Segundo Suri (2003), o sistema LM tem produzido resultados expressivos em muitas empresas e é, certamente, uma estratégia efetiva para o desenvolvimento de competência operacionais em empresas que operam em ambientes MTO.

Em função das oportunidades de melhoria propostas pelo grupo, foram escolhidas 6 dentre as 17 práticas do sistema LM propostas por Cua et al. (2001) e classificadas nos programas JIT, TPM, TQM e HRM. A Tabela 7 apresenta esta seleção:

Tabela 7 - Seleção de práticas do sistema LM

\begin{tabular}{lll}
\hline \multicolumn{1}{c}{ Oportunidades } & \multicolumn{1}{c}{ Práticas } & Programas \\
\hline Aumento da flexibilidade da MOD & Operadores polivalentes & HRM \\
$\begin{array}{ll}\text { Aumento da flexibilidade das máquinas } \\
\text { Redução da paradas nas máquinas }\end{array}$ & $\begin{array}{l}\text { Projeto de máquinas } \\
\text { Manutenção preventiva e autônoma }\end{array}$ & TPM \\
Redução do tempo de set-up & Redução do tempo de set-up & JIT \\
Melhoria na gestão do fornecimento & Fornecimento JIT \\
Reavaliação do sistema de PCP & Planejamento e controle da produção & \\
\hline
\end{tabular}

Fonte: elaborada pelo autor.

Segundo Melchert et al. (2006), após o delineamento das alternativas, critérios de seleção devem ser aplicados para o desenvolvimento da solução. Estes podem incluir:

- impacto sobre as dimensões competitivas;

- complexidade da implementação;

- investimentos envolvidos na implementação. 
A matriz de seleção de projetos, discutida no item 2.3.4, foi utilizada para auxiliar no processo de conferir prioridades à implementação das práticas do sistema LM. Segundo Klastorin (2004), a matriz de seleção de projetos é um documento que permite ao grupo sistematicamente identificar, analisar e avaliar a importância relativa de cada alternativa apresentada. Para sua construção, foram envolvidas as pessoas das áreas de Manufatura, Manutenção, Vendas, Compras e Recursos Humanos. O processo seguiu os seguintes passos, identificados na Figura 5:

1. Identificação das alternativas: as práticas selecionadas incluíam "operadores polivalentes", "projeto de máquinas", "manutenção preventiva e autônoma", "redução do tempo de set-up", "fornecimento JIT" e "planejamento e controle da produção".

2. Identificação dos critérios de seleção: incluía "impacto sobre as dimensões competitivas", "complexidade da implementação" e "investimentos envolvidos na implementação".

3. Atribuição de pesos: pesos diferentes deveriam ser atribuídos caso o grupo entendesse que alguns critérios fossem mais importantes que outros. Desta forma, no entendimento do grupo o impacto sobre as dimensões competitivas foi considerado o fator mais importante na decisão, seguido por investimento e complexidade da implementação. Logo, foram atribuídos os pesos 3, 2 e 1 respectivamente.

4. Definição do sistema de avaliação: seu objetivo foi determinar uma escala de pontuação e assegurar que os membros do grupo tivessem um entendimento comum de sua representação. Foram utilizados os seguintes critérios:

a. Impacto sobre as dimensões competitivas: foi utilizado como referência o estudo conduzido por Cua et al. (2001) sobre o impacto de práticas específicas do TQM, JIT, TPM e HRM acerca da melhoria dos indicadores de desempenho de custo, qualidade, entrega e flexibilidade, apresentado na Tabela 4. Uma vez que o benefício esperado pela empresa era o do desenvolvimento da habilidade de assegurar a aderências aos prazos de entrega e à redução dos tempos de produção, foram consideradas as 
pontuações referentes à dimensão "entrega", de forma que 5, 3 e 1 representam, respectivamente, uma forte, moderada e fraca correlação com a melhoria do desempenho.

b. Complexidade: a avaliação da complexidade levou em consideração as observações de Miyake (2002) sobre os três níveis envolvidos no processo de implementação de ferramentas do sistema LM, bem como os indicadores de complexidade de projeto apresentados na Tabela 6. Sendo assim, em função do número de departamentos e pessoas envolvidas no processo, além da programação de prazos, as pontuações 5, 3 e 1 representavam, respectivamente, uma baixa, média e alta complexidade de implementação.

c. Investimentos envolvidos na implementação: a avaliação dos investimentos considerou as mesmas observações do item anterior, porém aliadas à idéia de necessidade de aquisição de equipamentos, tecnologias, entre outros. Neste caso, as pontuações 5, 3 e 1 representavam, respectivamente, um baixo, médio e alto montante envolvido na implementação.

5. Avaliação das alternativas: conforme item anterior.

6. Totalização da pontuação: multiplicou-se a pontuação de cada critério de decisão por seu peso. Então, totalizou-se a pontuação referente a cada alternativa, definindo, assim, a prioridade de implementação para cada prática do sistema LM.

O resultado da matriz é demonstrado na Figura 18: 


\begin{tabular}{|c|c|c|c|c|c|c|c|c|c|}
\hline & \multicolumn{7}{|c|}{ Critérios } & & \\
\hline & \multicolumn{2}{|c|}{$\begin{array}{c}\text { Impacto sobre a } \\
\text { dimensão "entrega" }\end{array}$} & \multicolumn{2}{|c|}{$\begin{array}{c}\text { Complexidade da } \\
\text { implementação }\end{array}$} & \multicolumn{3}{|c|}{$\begin{array}{l}\text { Investimento na } \\
\text { implementação }\end{array}$} & & \\
\hline Alternativas Pesos & \multicolumn{2}{|r|}{3} & \multicolumn{2}{|c|}{1} & \multicolumn{3}{|c|}{2} & Total & Priorização \\
\hline Operadores polivalentes & \multicolumn{2}{|r|}{5} & \multicolumn{2}{|c|}{3} & \multicolumn{3}{|c|}{5} & 28 & $1^{\circ}$ \\
\hline Projeto de máquinas & \multicolumn{2}{|r|}{1} & \multicolumn{2}{|c|}{3} & \multicolumn{3}{|c|}{1} & 8 & $6^{\circ}$ \\
\hline Manutenção prev. e aut. & \multicolumn{2}{|r|}{3} & \multicolumn{2}{|c|}{3} & \multicolumn{3}{|c|}{5} & 22 & $3^{\circ}$ \\
\hline Redução de set-up & \multicolumn{2}{|r|}{1} & \multicolumn{2}{|c|}{3} & \multicolumn{3}{|c|}{3} & 12 & $5^{\circ}$ \\
\hline Fornecimento JIT & \multicolumn{2}{|r|}{3} & \multicolumn{2}{|c|}{1} & \multicolumn{3}{|c|}{5} & 20 & $4^{\circ}$ \\
\hline \multirow[t]{5}{*}{ PCP } & \multicolumn{2}{|r|}{5} & \multicolumn{2}{|c|}{3} & \multicolumn{3}{|c|}{3} & 24 & $2^{\circ}$ \\
\hline & \multicolumn{2}{|c|}{ Impacto } & \multicolumn{3}{|c|}{ Complexidade } & \multicolumn{3}{|c|}{ Investimento } & \\
\hline & 5 & Alto & 5 & Baix & & 5 & & & \\
\hline & 3 & Médio & 3 & Méd & & 3 & & & \\
\hline & 1 & Baixo & 1 & Altá & & 1 & & & \\
\hline
\end{tabular}

Fonte: elaborada pelo autor.

Figura 18 - Matriz de seleção de práticas do sistema LM

Do ponto de vista estratégico, estas alternativas fazem parte de categorias de decisão, principalmente infra-estruturais, as quais influenciam a força de trabalho, atividades de planejamento, controle e melhoria (SLACK et al., 2002). Estas decisões exercem um papel importante no desenvolvimento específico de competências operacionais a longo prazo.

O resultado desta matriz foi apresentado à alta gerência, bem como o cronograma de implementação das ações (Figura 19), o qual envolveria diversas áreas da empresa e solicitaria um alto comprometimento dos funcionários na obtenção dos resultados.

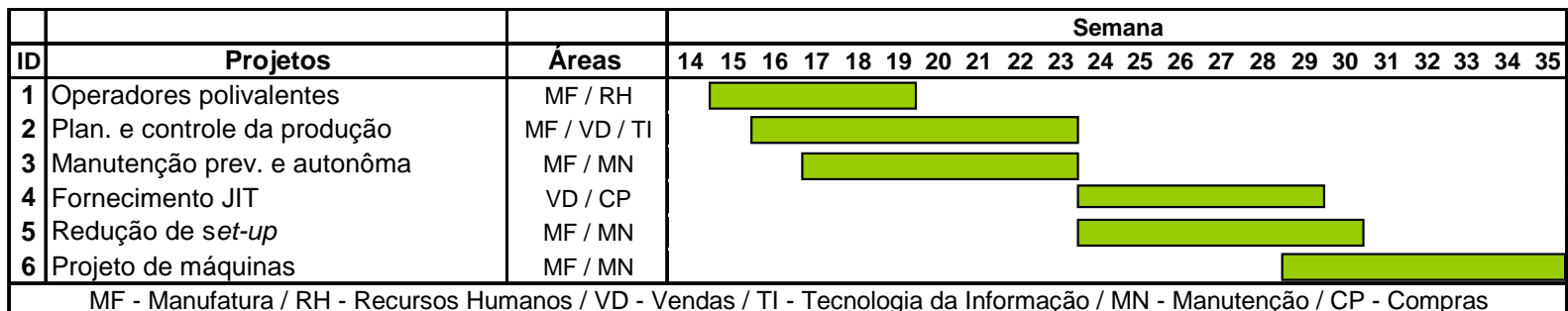

Fonte: elaborada pelo autor.

Figura 19 - Cronograma geral das ações 
Para evitar eventuais resistências na implementação das mudanças, foi acordado que haveria um intenso envolvimento dos funcionários no processo, incentivando as sugestões e compartilhando os resultados.

\subsection{Implementação das ações}

\section{Projeto desenvolvimento de operadores polivalentes}

Conforme o cronograma geral das ações definido anteriormente, o primeiro projeto implementado foi o desenvolvimento de operadores polivalentes (Figura 20). O principal objetivo era construir equipes eficientes e flexíveis para o benefício de cada um dos seus membros, de seus líderes e da empresa.

\begin{tabular}{|c|c|c|c|}
\hline & Operadores polivalentes & & Semana \\
\hline ID & Atividades & Áreas & $\begin{array}{lllllllllllllllllllllll}14 & 15 & 16 & 17 & 18 & 19 & 20 & 21 & 22 & 23 & 24 & 25 & 26 & 27 & 28 & 29 & 30 & 31 & 32 & 33 & 34 & 35 \\
\end{array}$ \\
\hline 1 & Levantar necessidades & $\mathrm{MF} / \mathrm{RH}$ & \\
\hline 2 & Análisar requisitos & MF & $\square$ \\
\hline 3 & Elaborar plano de treinamento & $\mathrm{MF} / \mathrm{RH}$ & 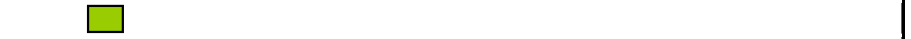 \\
\hline 4 & On the Job Trainning & MF & \\
\hline
\end{tabular}

Fonte: elaborada pelo autor.

Figura 20 - Cronograma de atividades (operadores polivalentes)

O desenvolvimento de operadores polivalentes não incluía somente a expansão do número de tarefas físicas que um operador era capaz de realizar, mas também novos papéis, como gerenciamento visual, manutenção autônoma, qualidade assegurada e efetivo trabalho em equipe.

Vale ressaltar que o levantamento das necessidades foi realizado conjuntamente ao supervisor e aos líderes de produção. Este trabalho compreendia desenvolver múltiplas habilidades nas equipes de auxiliares de embalagem, operadores de fabricação e operadores de sanitização. 
As atividades nas linhas de enchimento e embalagem são divididas em três fases distintas:

1. enchimento;

2. embalagem (rotulagem, tamponamento, colocação de lacre, etc.);

3. ponta de linha (controle de qualidade, embalagem secundária e apontamento de produção).

Cada uma destas três fases exigia diferentes habilidades dos auxiliares de embalagem, as quais, em virtude da especialização causada principalmente pelas atividades de enchimento e de ponta de linha, ocasionavam a falta de flexibilidade de mão-de-obra.

Os operadores de fabricação realizavam as atividades de conferência e adição das matérias-primas nos equipamentos conforme estabelecido no processo e descarga do granel; embora as atividades fossem praticamente as mesmas, algumas particularidades nos equipamentos ocasionavam a especialização do operador. O mesmo ocorria com os operadores de sanitização, cujas atividades eram a limpeza, a sanitização e a preparação dos equipamentos de acordo com a seqüência de produção.

O próximo passo foi analisar os requisitos e determinar a abrangência do programa. No caso dos operadores de fabricação e sanitização, a decisão tomada foi habilitar todos eles a operarem os diversos equipamentos, uma vez que já realizavam as mesmas atividades. No caso dos auxiliares de embalagem, de um total de 144 auxiliares, apenas 10 estavam capacitados à realização das atividades de enchimento; outros 20 às atividades de ponta de linha. O objetivo, em uma primeira etapa, era treinar mais 20 operadores para o enchimento e mais 20 para as pontas de linhas.

Para o desenvolvimento do plano de treinamento, os líderes de produção juntamente aos supervisores de produção e qualidade definiram candidatos potenciais dentro das equipes atuais (pós, sólidos e líquidos) para que pudessem 
realizar rodízios, substituindo um ao outro e, após este procedimento, aprender habilidades em outras linhas.

\section{Projeto PCP}

O projeto de PCP envolvia a seleção das alternativas, o detalhamento das necessidades, as adaptações no sistema, além do treinamento e da validação da solução (Figura 21). Uma equipe multifuncional envolvendo as áreas de Manufatura, Vendas e TI foi formada para a discussão e o direcionamento das atividades do projeto.

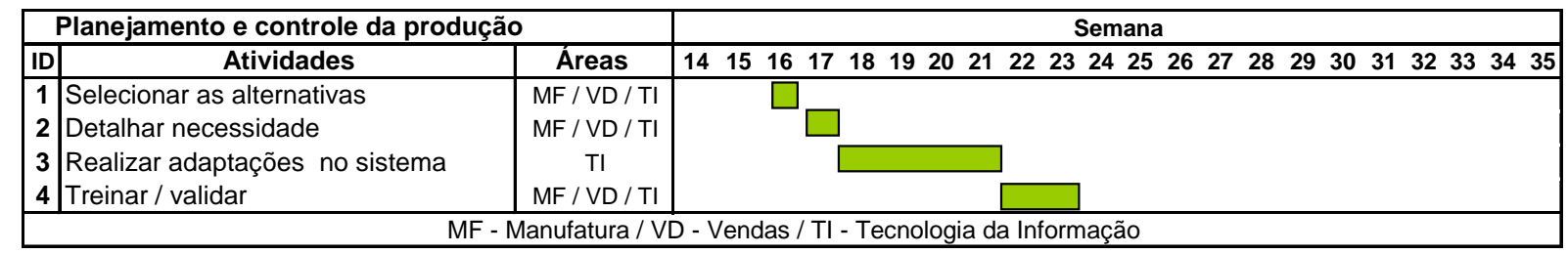

Fonte: elaborada pelo autor.

Figura 21 -Cronograma de atividades (planejamento e controle da produção)

Entre as alternativas discutidas na literatura, o conceito do WLC apresentavase como o sistema mais adequado às características da empresa em estudo, uma vez que as principais causas pelo baixo nível de desempenho nos indicadores estavam relacionadas à dificuldade de negociação de prazos, gerenciamento dos recursos e seqüenciamento das ordens de trabalho na manufatura. Assim, na fase de detalhamento das necessidades foram aprofundados os conceitos do sistema WLC, com especial ênfase para o desenvolvimento três módulos:

- consulta do cliente: módulo que permitiria a visualização do carregamento das ordens de trabalho na manufatura, auxiliando a negociação de prazos com o cliente; 
- entrada de pedidos: módulo próprio à visualização do total de pedidos pendentes no sistema;

- liberação de ordens: módulo que possibilitaria o seqüenciamento das ordens e o gerenciamento na capacidade na manufatura.

Devido às características técnicas do sistema ERP da empresa, o qual permite grande flexibilidade para inclusão e exclusão de módulos, o desenvolvimento dos novos módulos constituiu-se em uma tarefa relativamente simples. No entanto, para o correto funcionamento dos módulos de consulta do cliente e de liberação de ordens, foi necessária a revisão do esforço produtivo de cada produto, ou seja, a revisão de taxas de produção e do número de operadores envolvidos nesta.

A fase de treinamento e validação dos módulos, além das sugestões e melhorias apresentadas pelo grupo, foi uma oportunidade para que as equipes de Vendas e Manufatura entendessem suas necessidades e dificuldades, beneficiando, desta forma, o processo de integração entre as áreas.

\section{Projeto manutenção autônoma}

O projeto de manutenção autônoma envolvia quatro macro-atividades: determinar quais os equipamentos envolvidos no projeto; elaborar listas de verificação de limpeza, lubrificação e condições dos equipamentos; elaborar plano de treinamento e implementar as ações (Figura 22).

\begin{tabular}{|c|c|c|c|}
\hline & Manutenção autonôma & & Semana \\
\hline ID & Atividades & Áreas & \begin{tabular}{llllllllllllllllllllll|}
14 & 15 & 16 & 17 & 18 & 19 & 20 & 21 & 22 & 23 & 24 & 25 & 26 & 27 & 28 & 29 & 30 & 31 & 32 & 33 & 34 & 35 \\
\end{tabular} \\
\hline 1 & Determinar máquinas & MN & \\
\hline 2 & Preparar listas de verificação & $\mathrm{MN}$ & \\
\hline 3 & Elaborar plano de treinamento & $\mathrm{MF} / \mathrm{MN} / \mathrm{RH}$ & , \\
\hline 4 & On the Job Trainning & MF / MN & \\
\hline
\end{tabular}

Fonte: elaborada pelo autor.

Figura 22 - Cronograma de atividades (manutenção autônoma) 
Como especialista nas máquinas, o grupo de operadores de manutenção deveria centralizar suas ações em desenvolver sistemas de manutenção preventiva e preditiva, executar inspeções regulares para as principais máquinas, coletar dados estatísticos de manutenção e treinar operadores na operação das máquinas.

Por meio dos apontamentos de linha foi possível diagnosticar as principais ocorrências de manutenção, que estavam concentradas sobre as máquinas de enchimento automáticas das linhas 1 e 2 e nos equipamentos de ink-jet ${ }^{16}$, em geral.

O próximo passo da equipe foi a definição de uma lista de verificação para manutenção autônoma de cada equipamento, visando à eliminação de três fatores geradores de falhas nos equipamentos: limpeza inadequada, lubrificação inadequada e mau uso. Os procedimentos operacionais padrão (POP) foram revistos a fim de assegurarem a correta operação e, por conseguinte, eliminarem o mau uso.

No plano de treinamento, foram envolvidos os operadores de sanitização, responsáveis pelo set-up e preparação dos equipamentos, e auxiliares de embalagem, operadores diretos das máquinas citadas e responsáveis pela execução rigorosa do POP, lubrificação e pequenos ajustes.

\section{Projeto fornecimento JIT}

O projeto de fornecimento JIT envolveu as seguintes atividades: identificação dos principais fornecedores, acordos de nível de serviço (ANS), sistemas de avaliação e oportunidades de melhoria (Figura 23).

\footnotetext{
${ }^{16}$ Equipamentos ink-jet: impressora jato de tinta para marcação de caixas e produtos em geral.
} 


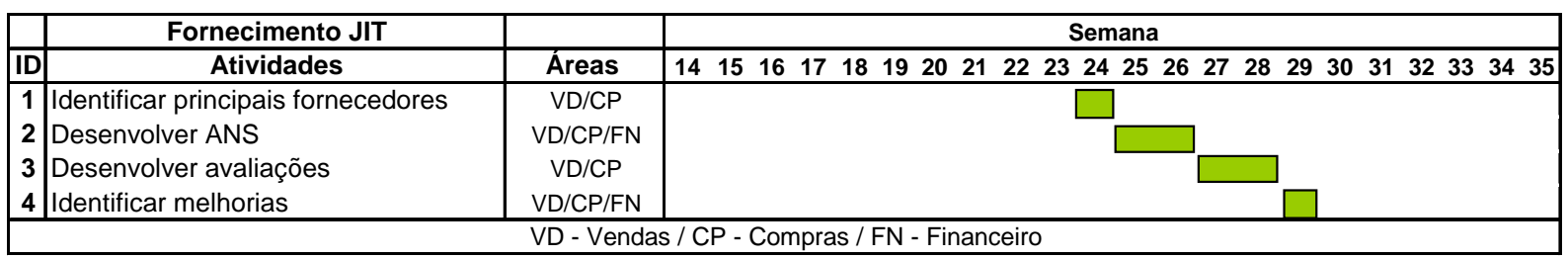

Fonte: elaborada pelo autor.

Figura 23 - Cronograma de atividades (fornecimento JIT)

Um fato interessante deste projeto é que muitos fornecedores eram clientes, logo o grande desafio enfrentado pelo grupo era demonstrar as mudanças que vinham ocorrendo na empresa, assim como a importância da participação deles para alcançar benefícios mútuos.

Com a finalidade de desenvolver os acordos deste nível foi necessário realizar uma avaliação do lead time interno da operação, possibilitando estimar prazos de entrega dos diferentes serviços prestados. O principal objetivo era estabelecer um prazo de fornecimento confiável e previsível para reduzir a variabilidade do processo e beneficiar o ciclo total do pedido, bem como a aderência aos prazos de entrega. Nesta fase, o lead time interno da manufatura já havia apresentado uma melhora com a implementação dos projetos anteriores, e a meta de entrega de sete dias foi estabelecida para o fornecedor.

Desta forma, o prazo de entrega acordado com o cliente deveria considerar sete dias para o fornecimento das matérias-primas, de granéis e de embalagens, além do tempo interno na manufatura, o qual varia em função da carga total de ordens por linhas de produção.

Foram desenvolvidas formas de avaliação, incorporadas ao sistema ERP da empresa; desta maneira, foram identificados os possíveis desvios, permitindo que planos de melhorias fossem desenvolvidos junto aos fornecedores. 


\section{Projeto redução do tempo de set-up}

Para o desenvolvimento do projeto de redução do tempo de set-up, foi formada uma equipe composta pelos operadores de sanitização e de manutenção (Figura 24). O foco inicial foi dado às máquinas da área de enchimento e embalagem, em especial às linhas de líquido, nas quais trabalha a grande maioria dos operadores.

\begin{tabular}{|c|c|c|c|}
\hline & Redução do set-up & & Semana \\
\hline ID & Atividades & Áreas & $\begin{array}{cccccccccccccccccccccc}14 & 15 & 16 & 17 & 18 & 19 & 20 & 21 & 22 & 23 & 24 & 25 & 26 & 27 & 28 & 29 & 30 & 31 & 32 & 33 & 34 & 35 \\
\end{array}$ \\
\hline 1 & Determinar máquinas & $\mathrm{MN}$ & \\
\hline 2 & Definir atividades int. / ext. & $\mathrm{MN}$ & \\
\hline 3 & Elaborar plano de treinamento & $\mathrm{MF} / \mathrm{MN} / \mathrm{RH}$ & $\square$ \\
\hline 4 & On the Job Trainning & $\mathrm{MF} / \mathrm{MN}$ & \\
\hline
\end{tabular}

Fonte: elaborada pelo autor.

Figura 24 - Cronograma de atividades (redução do tempo de set-up)

Durante a etapa de definição das atividades internas e externas do set-up, o grupo identificou que as tarefas de preparação e limpeza de bicos de enchimento e conexões poderiam ser transformadas em externas, necessitando, portanto, a determinação de um local apropriado para estas tarefas. A atividade de sanitização do equipamento permaneceu interna, porém foi avaliada, junto ao Departamento de Qualidade, a possibilidade da substituição do líquido saneante por outro de maior eficiência que permitisse reduzir o tempo desta atividade. O teste realizado com um novo líquido saneante possibilitou a redução em aproximadamente $50 \%$ do tempo de sanitização, correspondendo a uma redução de $33 \%$ do tempo total de set-up.

O trabalho prévio de desenvolvimento de polivalência realizado com os operadores de sanitização possibilitou o conhecimento das particularidades de cada equipamento; este fato, conseqüentemente, auxiliou no desenvolvimento de um kit set-up, contendo as diversas ferramentas e dispositivos utilizados na operação, visando à eliminação dos tempos de movimentação do operador. 
Definidos o novo processo, as instruções de trabalho e as seqüências de atividades, o passo seguinte foi elaborar o plano de treinamento. $O$ treinamento on the job foi realizado inicialmente em uma máquina "piloto" e, em seguida, estendida às demais máquinas. O monitoramento das ações foi conduzido por observações e discussões com os membros da equipe; também foram sugeridas adaptações no processo para a validação das ações propostas. Esta etapa tornou-se constante, visando à melhoria contínua do processo.

\section{Projeto de máquinas}

O último projeto visava, por meio de pequenas adaptações, ao aumento da flexibilidade das máquinas (Figura 25).

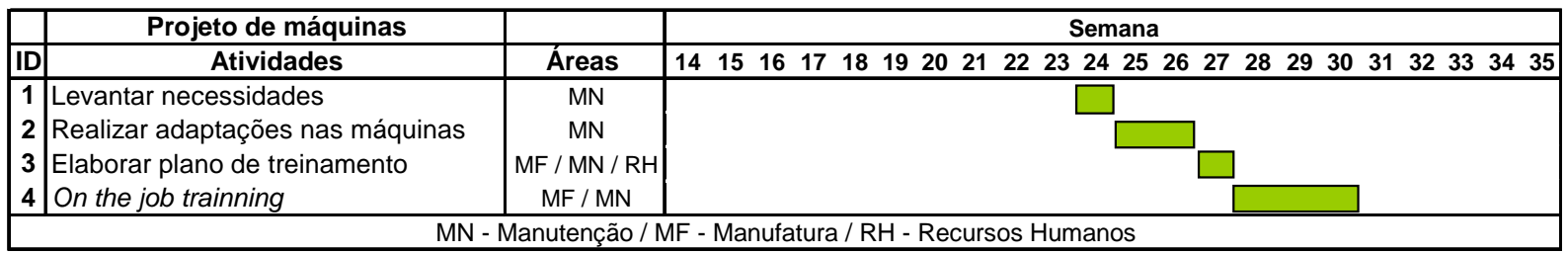

Fonte: elaborada pelo autor.

Figura 25 - Cronograma de atividades (projeto de máquinas)

Uma equipe formada por operadores de manutenção e o supervisor de produção discutiu as principais oportunidades na utilização desta técnica, sendo constatado que um dos fatores limitantes para obter flexibilidade nos equipamentos de enchimento estava no projeto dos bicos de enchimento - neste ponto, vale ressaltar que a velocidade de enchimento é influenciada pelas características físicoquímicas dos produtos e pelo projeto do próprio bico. Desta forma, optou-se pela adaptação destes para permitir a variação da velocidade de produção em função do total de carga de trabalho e dos recursos disponíveis. 
O trabalho de adaptação dos bicos de enchimento incluiu a construção de protótipos e a realização de vários testes até a sua validação. Uma nova tabela, correlacionando o tipo de bico de enchimento, a velocidade e o produto, foi desenvolvida e apresentada aos líderes de produção e operadores de sanitização para estabelecimento de um novo procedimento operacional.

A etapa seguinte consistiu em um treinamento on the job e monitoramento do processo visando à validação das modificações efetuadas.

\subsection{Análise dos resultados}

Conforme descrito anteriormente, fatores externos e internos motivaram a empresa a rever sua estratégia de manufatura visando ao atendimento aos requisitos do mercado. A implementação de um conjunto de práticas do sistema LM aliadas a um PCP adequado ao ambiente MTO representou decisões e ações tomadas pela empresa para suportar seus objetivos a longo prazo.

A implementação das práticas do sistema LM ocorreu de acordo com o mencionado no item 2.3.1, por intermédio do comprometimento da alta gerência na direção das mudanças, no envolvimento das pessoas e na revisão dos indicadores. A fase de análise foi coberta pela coleta de dados e análise dos problemas identificados no estado atual; durante a fase de decisão, um conjunto de práticas do sistema LM foi apresentado ao grupo a fim de selecionar os projetos a serem implementados.

O primeiro projeto implementado - operadores polivalentes - faz parte de um conjunto de práticas incluídas no programa de gerenciamento de Recursos Humanos (HRM). Segundo Cua et al. (2006), estas atividades são mecanismos de suporte para a implementação de outros programas, como TQM, JIT e TPM. Esta visão ficou evidenciada com a implementação da seqüência de projetos. 
A polivalência dos operadores suportou a implantação do novo conceito de PCP, agregando flexibilidade à MOD; este fato permitiu seu melhor aproveitamento nas atividades de seqüenciamento da produção e gerenciamento da capacidade. Como conseqüência, o indicador de eficiência foi afetado positivamente.

O sistema de PCP foi reorganizado com base nos conceitos do sistema WLC, exigindo o desenvolvimento de três módulos a serem incorporados ao ERP da empresa. O módulo de consulta do cliente (Figura 26) tornou-se à equipe de vendas um auxílio visual para a negociação das datas de entrega. O gráfico demonstra a carga de trabalho total por linha em um horizonte de 30 dias. Caso o cliente solicitasse uma redução no prazo de entrega, o analista de PCP era envolvido para verificar a possibilidade de mudança da capacidade do recurso gargalo na data apropriada, aumentando, assim, a capacidade de produção diária e, conseqüentemente, reduzindo o total de pedidos pendentes.

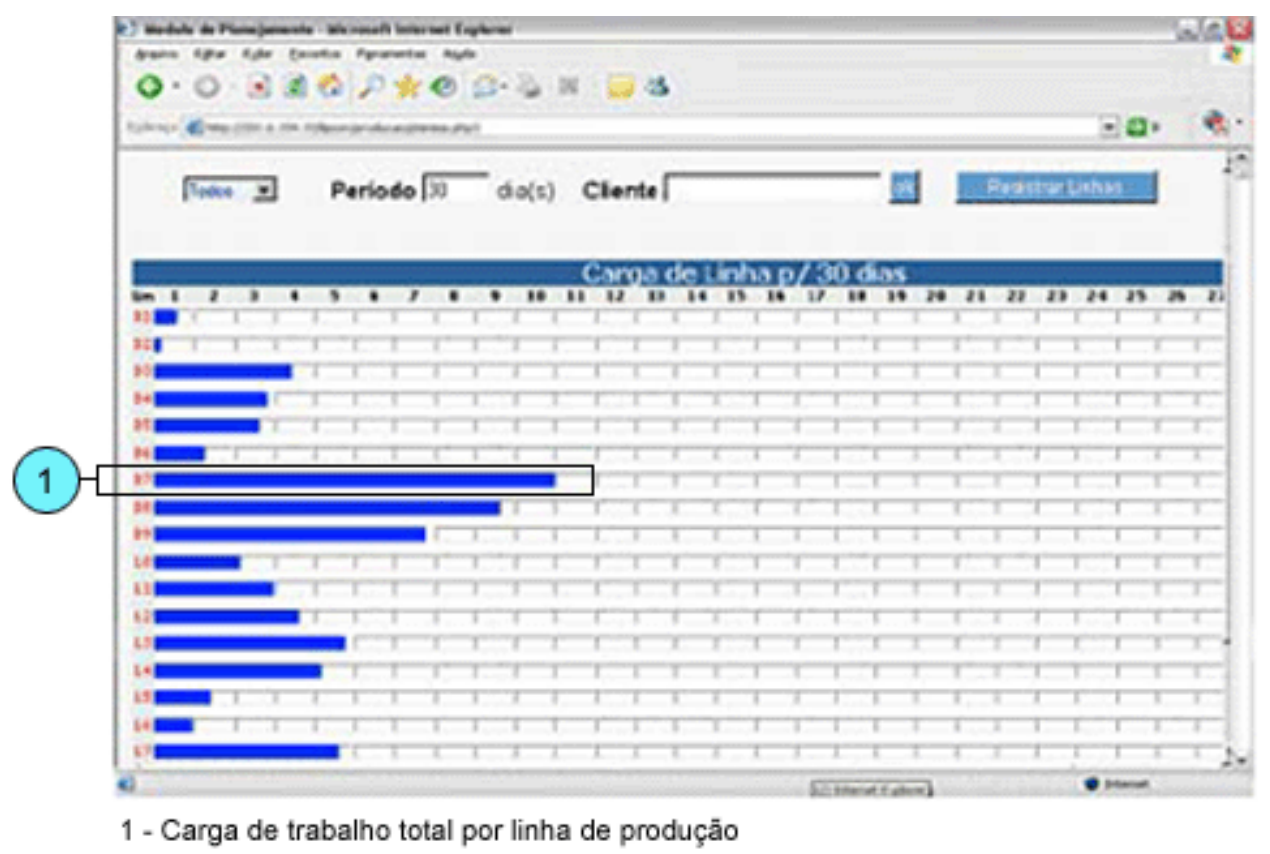

Fonte: extraída do ERP da empresa objeto de estudo.

Figura 26 - Módulo de consulta do cliente

O módulo de entrada de pedidos (Figura 27) permitiu ao analista de PCP ter um controle melhor sobre o total de pedidos pendentes e seus respectivos prazos de 
entrega. Logo, ele seria capaz de realizar um planejamento mais detalhado do seqüenciamento das ordens e do gerenciamento da capacidade.

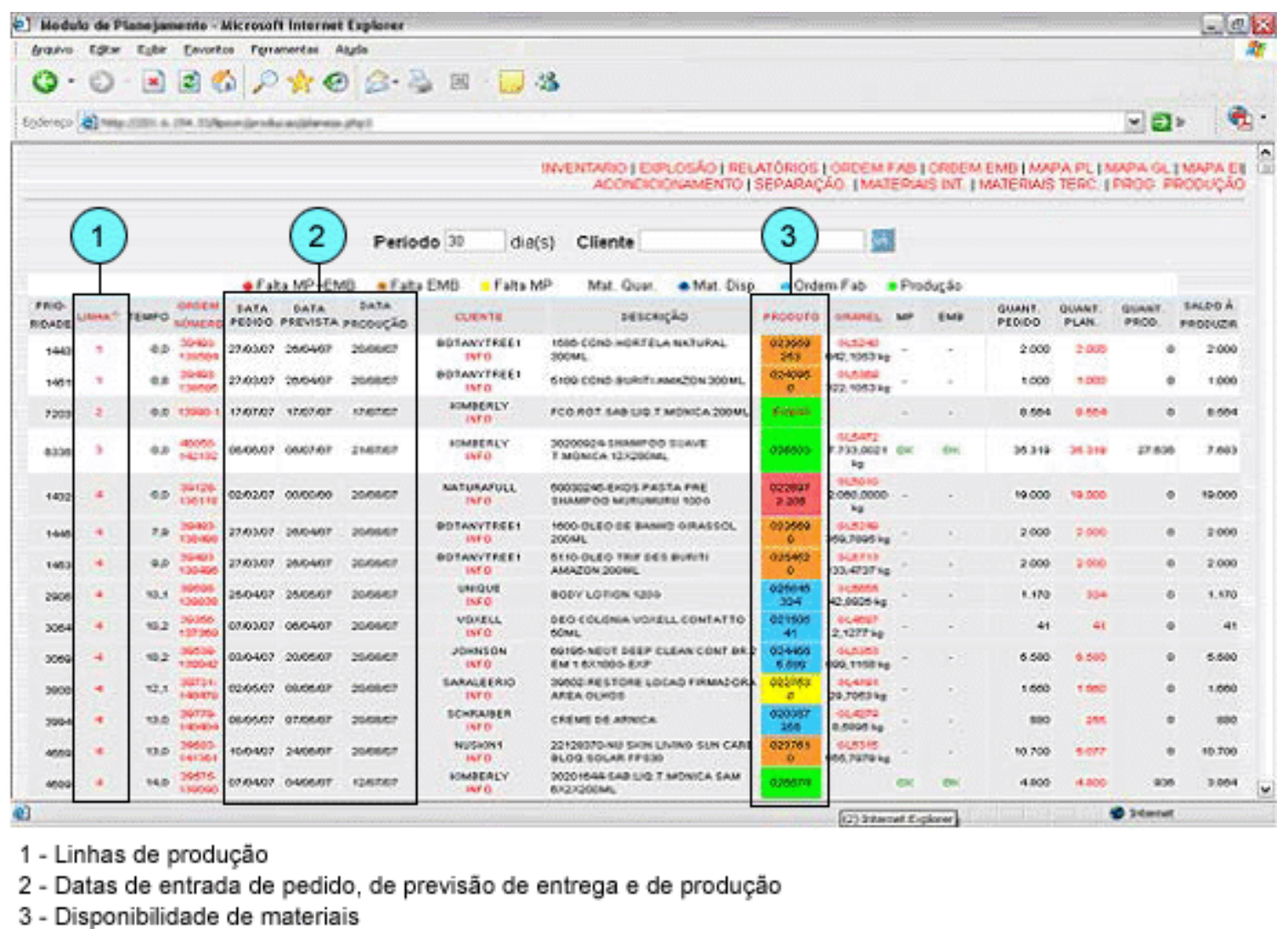

Fonte: extraída do ERP da empresa objeto de estudo.

Figura 27 - Módulo de entrada de pedidos

Finalmente, o módulo de liberação de ordens (Figura 28) auxiliou o analista de PCP a planejar e seqüenciar as ordens de trabalho. O monitoramento hora a hora dos recursos alocados permite a ele identificar sobrecarga ou subutilização dos recursos. Uma vez que os operadores são polivalentes, o analista está apto a avaliar os requisitos das ordens eminentes e realocar os recursos para linhas específicas, aumentando, desta forma, a taxa de produção. O módulo também permitia a visualização da eficiência e capacidade planejada. 


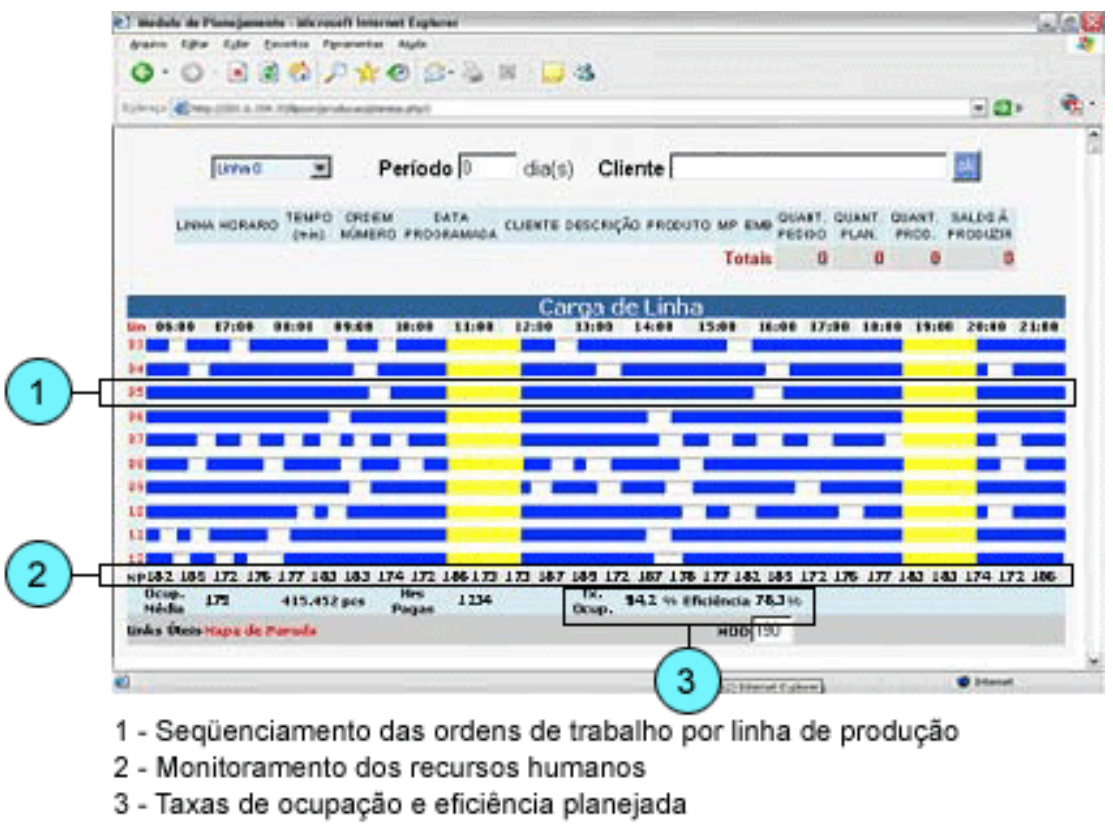

Fonte: extraída do ERP da empresa objeto de estudo.

Figura 28 - Módulo de liberação de ordens

A implementação do projeto de manutenção autônoma gerou um impacto significativo na redução das intervenções não programadas da manutenção, tendo, assim, um caráter complementar ao projeto de polivalência dos operadores. Em geral, o programa teve uma boa aceitação entre os operadores, uma vez que muitos atribuíram a esta nova atividade um senso de orgulho e propriedade.

O projeto de fornecimento JIT apresentou uma característica interessante: uma vez que os clientes também eram fornecedores, tornava-se fundamental o cumprimento das datas de entrega para benefício mútuo. A implementação do projeto de PCP auxiliou a empresa no entendimento de sua real capacidade produtiva bem como a melhoria do planejamento e controle das ordens. Logo, os acordos no âmbito do nível de serviço desenvolvidos foram fundamentais para a melhoria de desempenho refletida no indicador de aderência ao prazo de entrega.

No projeto de redução do tempo de set-up, o objetivo do grupo foi totalmente satisfeito: os resultados obtidos com a redução de 33\% do tempo médio de set-up mantiveram o grupo sempre motivado na busca de novas alternativas. Esta meta 
alcançada contribuiu positivamente com os vários indicadores, tornando-se uma importante ferramenta na incorporação de flexibilidade na manufatura.

Esta flexibilidade também foi beneficiada com o projeto de máquinas. Alcançou-se este resultado por intermédio da adaptação dos bicos de enchimento assim como da revisão dos procedimentos operacionais; desta maneira, as máquinas passaram operar com uma variedade maior de produtos e taxas de produção variável.

O impacto destas ações em cada indicador de desempenho é demonstrado nos Gráficos 5, 6, 7 e 8:

\section{Entrega}

Aderência ao prazo de entrega

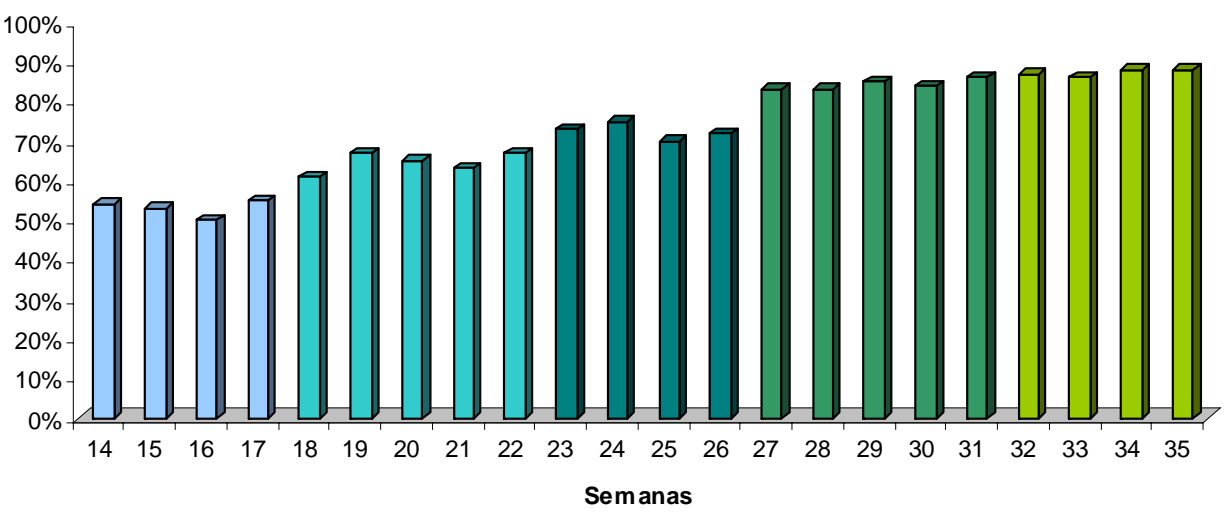

Fonte: elaborado pelo autor.

Gráfico 5 - Aderência ao prazo de entrega após implementação 
Tempo de ciclo do pedido (dias)

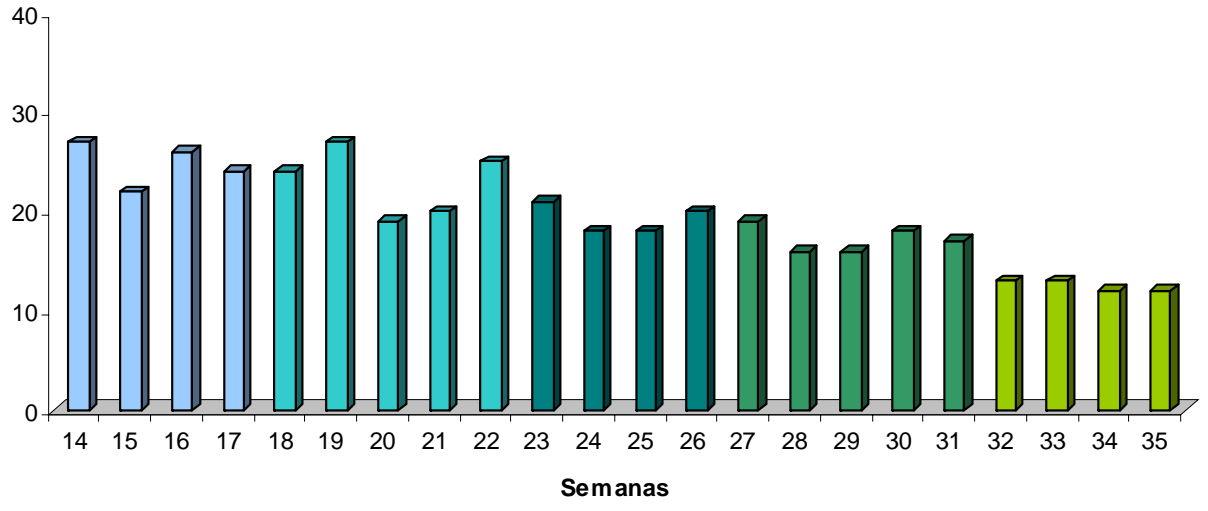

Fonte: elaborado pelo autor.

Gráfico 6 - Tempo de ciclo do pedido após implementação

\section{Custo}

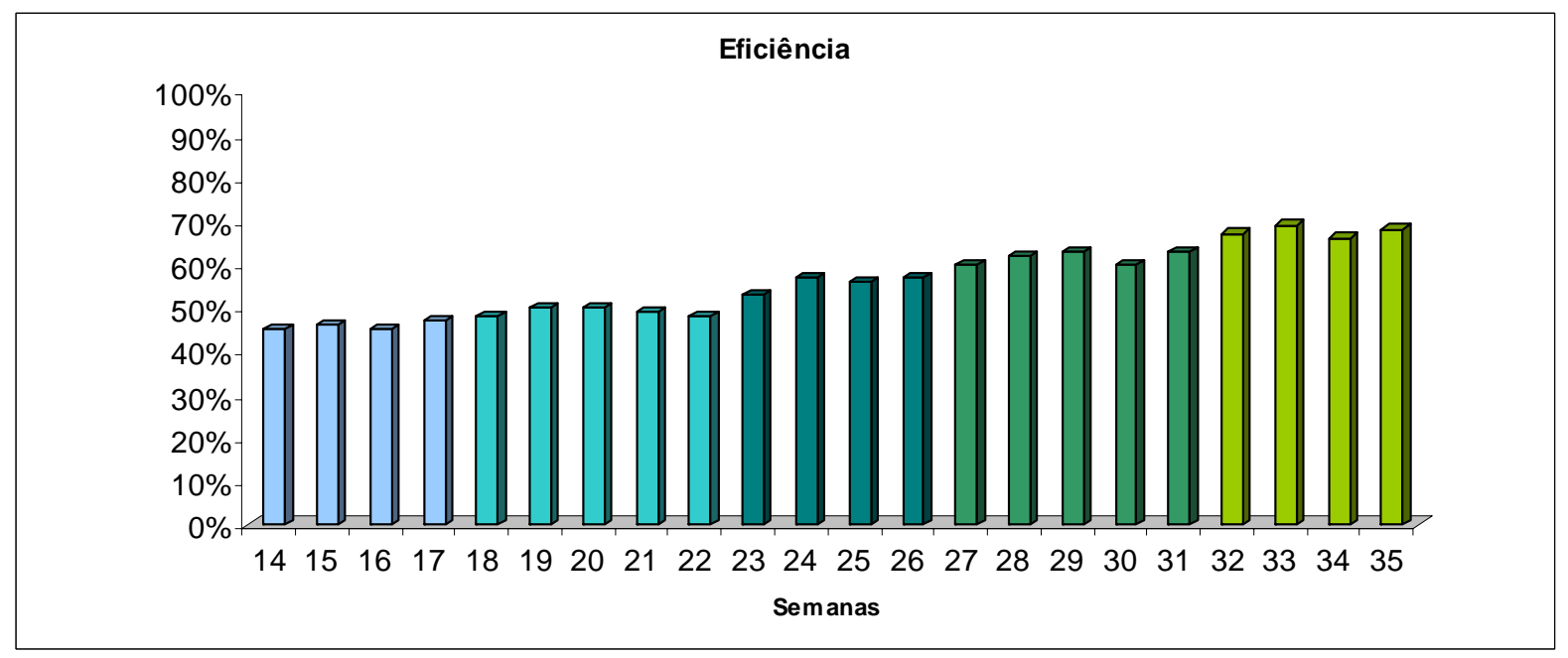

Fonte: elaborado pelo autor.

Gráfico 7 - Eficiência da manufatura após implementação

O Gráfico 8 relaciona a eficiência às principais perdas da manufatura. 


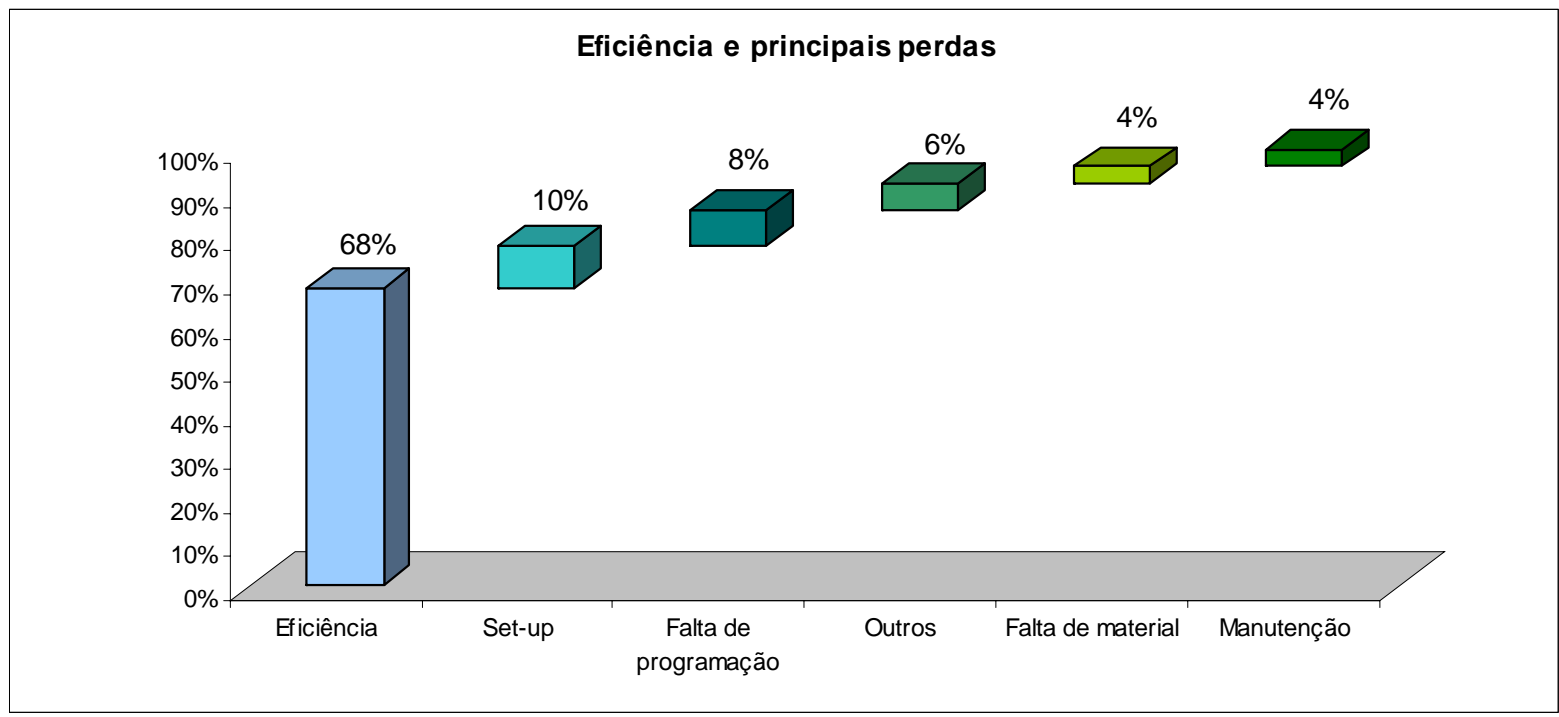

Fonte: elaborado pelo autor.

Gráfico 8 - Eficiência da manufatura e principais perdas após implementação

A Tabela 8 sumariza o histórico dos indicadores visando à comparação entre os desempenhos anteriores com os obtidos após a implementação:

Tabela 8 - Comparação de desempenho anterior versus posterior

\begin{tabular}{lcc}
\multicolumn{1}{c}{ Indicador } & Desempenho anterior & Desempenho posterior \\
\hline Eficiência & $45 \%$ & $68 \%$ \\
Tempo de ciclo do pedido (dias) & 25 & 12 \\
Aderência ao prazo de entrega & $50 \%$ & $87 \%$ \\
\hline
\end{tabular}

Fonte: elaborada pelo autor.

O sistema de mensuração implementado permitiu o julgamento da efetividade das ações sobre os indicadores de desempenho, de forma que os mesmos puderam ser comparados antes e depois da implementação. Uma análise complementar pôde ser realizada com o intuito de avaliar se a proporção do volume demandado para cada tipo de serviço foi alterada ao longo deste estudo. Este fato poderia exercer certa influência nos resultados, uma vez que os tempos envolvidos nas atividades realizadas pelos clientes e o das realizadas pela empresa variam de acordo com o tipo de serviço prestado. Os dados do Gráfico 9 revelaram que a proporção foi praticamente mantida validando desta maneira a efetividade das ações. 


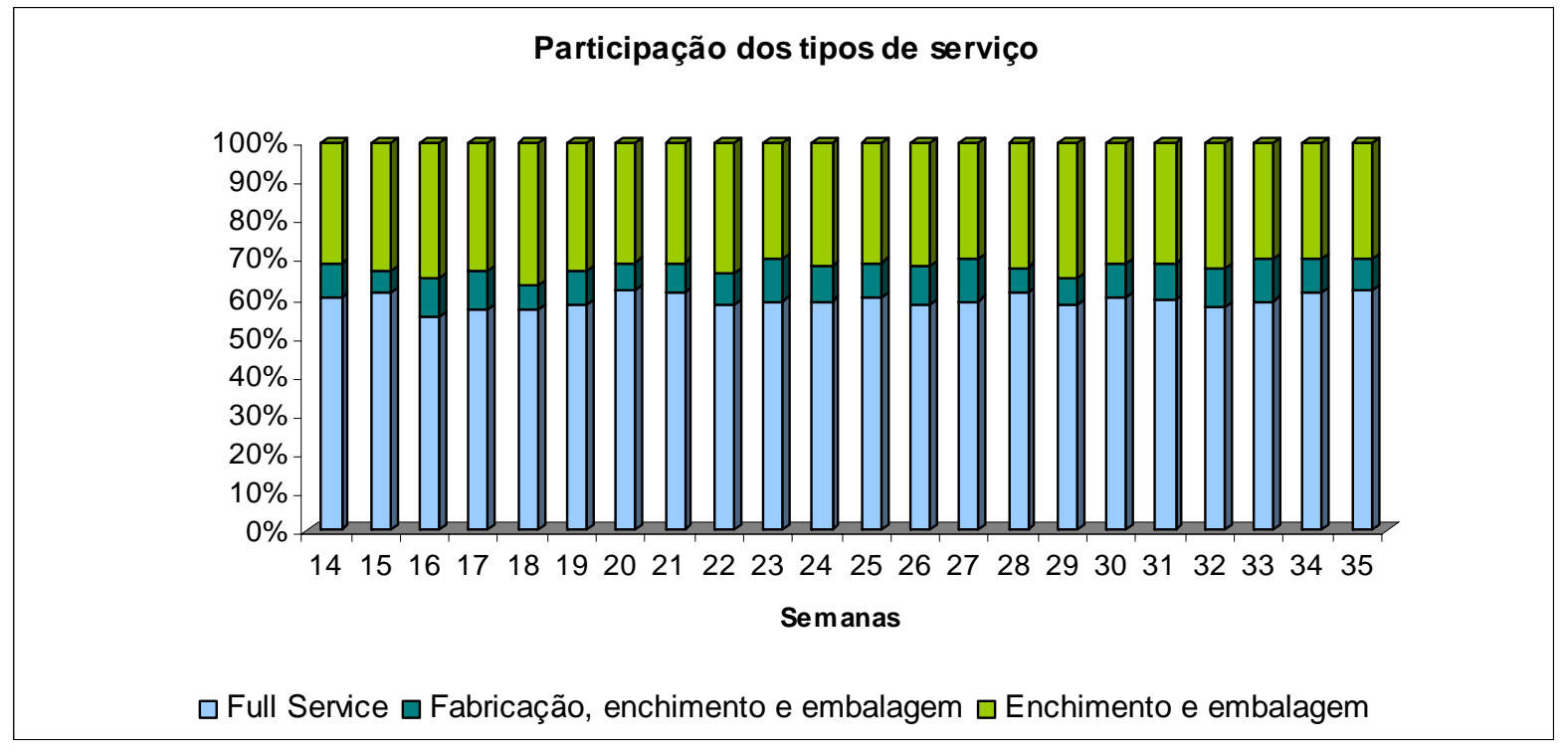

Fonte: elaborado pelo autor.

Gráfico 9 - Participação dos tipos de serviços nos volumes totais produzidos

Logo, os objetivos da empresa foram satisfeitos por meio da implementação de um conjunto de ações visando ao cumprimento dos prazos e a redução dos tempos de entrega.

Vale ressaltar que as práticas implementadas apresentaram diferentes características quanto ao impacto nos indicadores de desempenho. Algumas, como o sistema de PCP, fornecimento JIT e manutenção autônoma, foram essenciais para melhoria de desempenho dos indicadores. Outras práticas, como a redução do set-up e o desenvolvimento de máquinas, forneceram impactos incrementais, porém não menos importantes. O desenvolvimento de operadores polivalentes adquiriu a função de viabilizar e suportar a implementação das demais práticas.

O caráter participativo do estudo auxiliou no desenvolvimento de uma consciência voltada à utilização de melhores práticas e à busca pela melhoria contínua. O fato contribui para futuras discussões sobre revisões de estratégias na empresa. 


\section{Conclusão}

\section{CAPÍtulo 5}

O objetivo geral do presente trabalho foi analisar como práticas do sistema Lean Manufacturing (LM) poderiam ser efetivamente implementadas em conjunto a um sistema de planejamento e controle da produção (PCP) apropriado, visando ao desenvolvimento competências operacionais alinhadas à política MTO. Os objetivos específicos do estudo concentraram-se em identificar na literatura as principais competências operacionais requeridas no ambiente MTO, discutir o processo de implementação de práticas do sistema LM e comparar, conceitualmente, sistemas de PCP. A revisão teórica permitiu uma melhor compreensão do objetivo geral, direcionando as seguintes proposições a serem confirmadas:

P1: A adoção de práticas do sistema $L M$ auxilia as empresas que operam em ambientes MTO a desenvolverem competências operacionais alinhadas aos requisitos do mercado.

A adoção de práticas do sistema $L M$, do ponto de vista estratégico, representa decisões e ações que exercem um papel importante no desenvolvimento específico de competências a longo prazo, uma vez que direcionam melhorias na manufatura e refletem mudanças em sua estratégia. Assim, esta iniciativa estratégica deve procurar impulsionar as competências existentes ou desenvolver as necessárias, atualmente faltantes.

No caso estudado, os requisitos do mercado se concentravam na rapidez e na confiabilidade da entrega. Portanto, as competências operacionais requeridas para atender a estes requisitos eram a habilidade de fornecer entregas rápidas, assegurar a aderência aos prazos de entrega e reduzir o tempo de produção. Além disso, ter uma operação flexível auxiliaria a mantê-la dentro do programado quando eventuais imprevistos perturbassem o plano. 
Embora as organizações pioneiras na implementação do sistema LM pertencessem a uma cadeia produtiva relativamente estável, algumas práticas que foram adotadas no estudo demonstraram-se eficazes inclusive no ambiente MTO caracterizado pelas incertezas envolvendo tanto os tipos de produtos como os volumes que serão demandados.

A adoção da prática "operadores polivalentes" agregou flexibilidade à MOD, permitindo seu melhor aproveitamento nas atividades de seqüenciamento da produção e gerenciamento da capacidade, mantendo, desta forma, a operação dentro do programado.

A prática "projeto de máquinas" favoreceu o aumento de flexibilidade da operação por meio de adaptações realizadas nos bicos de enchimento, permitindo que as máquinas passassem a operar com uma variedade maior de produtos e taxas de produção variáveis.

A utilização dos conceitos do "fornecimento JIT" possibilitou integrar os fornecedores e clientes ao sistema de produção, beneficiando tanto o tempo de ciclo do pedido como a aderência aos prazos de entrega. Essa integração ocorreu por meio do estabelecimento de acordos quanto ao nível de serviço, implementação de um sistema de avaliação e desenvolvimento de ações em conjunto para melhoria do processo. Quando analisadas as principais perdas de eficiência da manufatura, houve uma redução de $10 \%$ para $4 \%$ da falta de materiais ocasionada por atrasos no fornecimento. $O$ tempo médio de fornecimento também foi reduzido de 15 para 7 dias.

As perdas ocasionadas por intervenções de manutenção nas máquinas foram reduzidas em 43\% devido às ações preventivas desenvolvidas com o projeto "manutenção autônoma", auxiliando na diminuição dos tempos de produção. Este quesito também foi impactado pela "redução do tempo de set-up" alcançada com redefinição das atividades internas e externas, operação do procedimento de set-up, alteração do líquido saneante e desenvolvimento de um kit contendo ferramentas e dispositivos utilizados neste processo. 
Estas práticas auxiliaram a empresa no desenvolvimento da habilidade de reduzir o tempo de produção, fornecer entregas rápidas e assimilar eventuais imprevistos causados por mudanças na programação. No entanto, a grande contribuição para assegurar a aderência ao prazo de entrega ocorreu com a implementação de um sistema de PCP apropriado - o WLC - que, por intermédio da melhoria nos processos de determinação de prazos de entrega, planejamento da capacidade e seqüenciamento de ordens, possibilitaram à empresa atingir 87\% neste indicador.

Logo, a proposição foi confirmada em parte, pois a adoção de práticas do sistema LM auxilia de forma significativa, porém não seria suficiente para o desenvolvimento de competências operacionais em ambientes MTO.

P2: A seleção e implementação de práticas do sistema $L M$ são baseadas em contextos específicos que incluem tanto fatores externos como internos da empresa.

As empresas de manufatura contratada são submetidas a fortes influências das empresas contratantes em vários níveis de decisão. No caso da empresa estudada, tais interferências estavam presentes tanto na definição de prazo como na necessidade freqüente de alterações de datas de entrega. A dificuldade para atender a estes requisitos motivou a empresa a rever a sua estratégia.

O processo de formulação da estratégia envolve a avaliação de fatores externos e internos, a análise do desempenho atual, a definição de objetivos e o desenvolvimento de um conjunto de ações.

Neste caso, o próximo passo dado pela empresa em tal sentido foi a definição de indicadores de desempenho relacionados aos requisitos do mercado com o intuito de analisar a sua situação atual, definir objetivos e ações a serem implementadas.

Os indicadores de desempenho escolhidos - aderência ao prazo de entrega e tempo de ciclo do pedido - relacionavam-se ao objetivo da empresa que enfatizava 
a importância da dimensão entrega. O baixo desempenho nestes indicadores, 50\% e 25 dias respectivamente, exigiu uma análise detalhada das possíveis causas para a definição de ações mais efetivas.

O exame das causas revelou que as ações deveriam concentrar-se no aumento da flexibilidade da MOD, no aumento de flexibilidade das máquinas, na redução das paradas de máquinas, na redução do tempo de set-up, na melhoria na gestão do fornecimento, assim como na reavaliação do sistema de PCP. Deste modo, foram propostas as práticas "operadores polivalentes", "projeto de máquinas", "manutenção preventiva e autônoma", "redução do tempo de set-up", "fornecimento JIT" e "PCP".

Portanto, a seleção de práticas do sistema LM foi baseada em contextos específicos, considerando tanto fatores externos, focados na dimensão entrega, como fatores internos, evidenciados pelas oportunidades de melhoria identificadas na produção.

Quanto ao processo de implementação, foram destacados três critérios para a priorização dos projetos. O primeiro avaliava qual o impacto de cada prática selecionada na melhoria dos indicadores de desempenho de entrega; o segundo, a complexidade envolvida na implementação de cada prática, ou seja, o número de departamentos, pessoas e prazos envolvidos; por último, os investimentos associados à necessidade de aquisição de equipamento, tecnologia, etc. Vale relembrar que estes critérios levaram em consideração fatores externos e internos da empresa.

Logo, a proposição foi confirmada e corrobora com a afirmação de que cada empresa segue uma trajetória particular quando analisada a seqüência pela qual diferentes práticas do LM são implementadas.

P3: O sistema WLC é mais eficaz que o MRP tradicional, em ambiente MTO, pois melhora a definição de prazos junto ao cliente, o gerenciamento da capacidade e o seqüenciamento das ordens na produção. 
O sistema de MRP da empresa desempenhava as funções de requisição e separação de materiais, além da liberação de ordens para a produção; na gestão de materiais era notória a importância desse sistema. Entretanto, não bastava garantir a disponibilidade de materiais para que os produtos fossem produzidos na data requerida pelo cliente, era necessário saber se existia capacidade suficiente de recursos humanos e de máquinas para realizar a produção sugerida pelo MRP no prazo determinado. Este ponto é particularmente importante para ambientes MTO cujo foco do planejamento da produção está no atendimento dos prazos de entrega.

As dificuldades enfrentadas pela empresa para negociar prazos com os clientes, gerenciar recursos e seqüenciar as ordens de produção foram os principais problemas atribuídos ao sistema MRP da empresa. Como solução, foram incorporados ao ERP da empresa três módulos que adotavam os conceitos do sistema WLC.

O módulo de consulta do cliente tinha como objetivo melhorar a definição de prazos junto aos clientes, considerando a negociação sob a ótica da programação de produção e o cumprimento deles. A inclusão deste módulo permitiu à equipe de vendas utilizar as informações sobre a carga total de trabalho por linha e atrasos esperados com a finalidade de estimar os prazos de entrega. Caso houvesse a necessidade de redução do prazo, este poderia ser conseguido por meio da mudança da capacidade do recurso gargalo, realocando operadores de um recurso subutilizado, utilizando horas extras ou contratando MOD temporária.

O módulo de entrada de pedidos forneceu ao analista de PCP a oportunidade de realizar um planejamento mais detalhado para a carga total de trabalho com base nas respectivas datas de entrega e na situação de cada pedido em relação à disponibilidade dos materiais necessários à produção de determinado item. Garantida a disponibilidade dos materiais, o próximo passo era seqüenciar as ordens na produção, realizado com auxílio do módulo de liberação de ordens.

Tal módulo ofereceu uma representação gráfica das ordens seqüenciadas na produção além do monitoramento hora a hora dos recursos alocados, da eficiência e 
da capacidade planejada. Desse modo, tornou-se possível identificar se os recursos humanos e máquinas eram suficientes para cumprir o plano no prazo determinado.

Portanto, as melhorias obtidas na definição de prazos junto ao cliente, no gerenciamento da capacidade e no seqüenciamento das ordens na produção com a implementação do WLC confirmam sua maior eficácia sobre o MRP tradicional no ambiente MTO.

Desse modo, o objetivo geral do trabalho foi alcançado, permitindo concluir que adoção de práticas do sistema LM, baseada em contextos específicos, auxilia de forma significativa no desenvolvimento de competências operacionais em empresas que operam em ambientes MTO. No entanto, é necessário que estas práticas estejam associadas a um sistema de PCP apropriado - Workload Control (WLC) - para que se obtenham os resultados esperados.

Este trabalho contribuiu para preencher uma lacuna existente na literatura referente às empresas que operam em ambiente MTO, na qual a maioria dos textos - relacionados com a adoção de melhores práticas de manufatura - é direcionada ao ambiente MTS. Deste modo, a presente pesquisa concentrou-se em demonstrar a aplicabilidade do LM em ambientes MTO com particular foco nas atividades de planejamento e controle da produção. 


\section{Referências}

BHASIN, S.; BURCHER, P. Lean viewed as a philosophy. Journal of Manufacturing Technology Management, v.17, n.1, p. 56-72, 2006.

BOYER, K. K.; LEWIS, M. W. Competitive priorities: investigating the need for tradeoffs in operations strategy. Production and Operations Management, v. 11, n.1, p.9-20, Spring 2002.

COUGHLAN, P.; COGHLAN, D. Action research for operations management. International Journal of Operations \& Production Management, v.22, n.2, p.220240, 2002.

CHASE, R.; JACOBS, F. R.; AQUILANO, N. Administração da Produção para a Vantagem Competitiva. 10 ed. Porto Alegre: Bookman, 2006.

CORREAA, H. L.; GIANESI, I. G. N. Just in time, MRP II e OPT: um enfoque estratégico. São Paulo: Atlas, 1993.

São Paulo: Atlas, 2001.

; CAON, M. Planejamento, programação e controle da produção.

CUA, K. O.; MCKONE, K. E.; SCHROEDER, R. G. Relationships between implementation of TQM, JIT, and TPM manufacturing performance. Journal of Operations Management, v.19, p. 675-694, 2001.

program. The Quality Management Journal, v. 13, n. 3, p. 45-60, 2006.

DAVIS, M. M.; AQUILANO, N. J.; CAHSE, R. B. Fundamentos da administração da produção. 3.ed. Porto Alegre: Bookman, 2001.

GRÖBLER, A.; GRÜBNER, A. An empirical model of the relationships between manufacturing capabilities. International Journal of Operations \& Production Management, v. 26, n. 5, p.458-485, 2006.

GARVIN, D. A. Competing on the eight dimensions of quality. Harvard Business Review, Nov/Dec, p.101-109, 1987. 
HAYES, R.; PISANO, G. P. Manufacturing strategy: at the intersection of two paradigm shifts. Production and Operations Management, v. 5, n. 1, p. 25-41, 1996.

.; WHEELWRIGHT, S. Restoring our competitive edge: competing through manufacturing. New York: Wiley, 1984.

;; PISANO, G.; UPTON, D.; WHEELWRIGHT, S. Operations, strategy and technology - Pursuing the competitive edge. Hoboken: John Wiley \& Sons, 2005.

HALLGREN, M.; OLHAGER, J. Differentiating manufacturing focus. International Journal of Production Research, v. 44, n.18-19, p.3863-3878, Oct 2006.

HASKOSE, A.; KINGSMAN, B.G.; WORTHINGTON, D. Performance analysis of make-to-order manufacturing systems under different workload control regimes. International Journal of Production Economics, v.90, p. 169-186, 2004.

HENRICH, P.; LAND, M.; GAALMAN, G. Exploring applicability of the workload control concept. International Journal of Production Economics, v. 90, p. 187198, 2004.

HILL, T. Manufacturing Strategy. Hampshire: Palgrave, 2000.

HINES, P.; HOLWE, M.; RICH, N. Learning to evolve: a review of contemporary lean thinking. International Journal of Operation \& Production Management, v.24, n.910, p.994-1011, 2004.

HIRANO, H. JIT factory revolution: a pictorial guide to factory design of the future. Portland: Productivity Press, 1988.

HOLWEG, M. The three dimensions of responsiveness. International Journal of Operations \& Production Management, v. 25, n.7, p. 603-622, 2005.

HOPP, W. J.; SPEARMAN, M.L. To pull or not to pull: what is the question? Manufacturing \& Service Operations Management, v.6, n.2, p. 133-147, Spring 2004.

JUNG, J. Y.; LIM, S.G. Project categorization, priorization, and execution based on six sigma concept: a case study of operational improvement project. Project Management Journal, v. 38, n.1, p. 55-60, Mar. 2007.

KINGSMAN, B. G. Modelling input-output workload control for dynamic capacity planning in production planning systems. International Journal of Production Economics, v. 68, p. 73-93, 2000. 
KLASTORIN, T. Project management tools and trade-offs. Hoboken: John Wiley \& Sons, 2004.

LEWIS, M. A. Lean production and sustainable competitive advantage. International Journal of Operations \& Production Management, v.20, n.8, p.959-978, 2000.

LOUIS, R. Integrating Kanban with MRPII: automating a pull system for enhanced JIT inventory management. Portland: Productivity Press, 1997.

MELCHERT, E. R.; FRANCISCHINI, P. G. Análise comparativa de sistemas híbridos de controle da produção e sua adequação ao novo ambiente competitivo. XXV Encontro Nacional de Engenharia de Produção. Anais... Porto Alegre, 2005.

$\therefore$ MONTOYA, C. V.; MIYAKE, D. I. Planejamento do processo de implementação do sistema lean utilizando a análise hierárquica do processo (AHP): um estudo de caso. IX Simpósio de Administração da Produção, Logística e Operações Internacionais. Anais... São Paulo, 2006.

MIYAKE, D. I. Melhorando o processo: seis sigma e sistema de produção lean. In: ROTONDARO, R. G. (Org). Seis Sigma: estratégia gerencial para melhoria de processos, produtos e serviços. São Paulo: Atlas, 2002.

NAKAJIMA, S. Introdução ao TPM: total productive maintenance. São Paulo: IMC - Internacional Sistemas Educativos,1989.

OLHAGER, J. Strategic positioning of the order penetration point. International Journal of Production Economics, v. 85, n. 3, p. 319-329, 2003.

.; RUDBERG, M. Manufacturing strategy and e-business: an exploratory study. Integrated Manufacturing Systems, v. 14, n. 4, p. 334-345, 2003.

.; SELLDIN, E. Manufacturing planning and control approaches: market alignment and performance. International Journal of Production Research, v. 45, n. 6, p. 1469-1484, Mar. 2007.

PAPADOPOULOU, T.C.; ÖZBAYRAK, M. Leanness: experiences from the journey to date. Journal of Manufacturing Technology Management, v.16, n.7, p.784-807, 2005.

PLATTS, K. W.; MILLS, J. F.; BOURNE, M. C.; NEELY, A. D.; RICHARDS, A. H.; GREGORY, M. J. Testing manufacturing strategy formulation processes. International Journal of Production Economics, v. 56-57, n. 1, p. 517-523, 1998.

PLATTS, K.; TAN, K. H. Strategy visualization: knowing, understanding, and formulating. Management Decision, v. 42, n. 5-6, p. 667-676, 2004. 
RUDBERG, M.; OLHAGER, J. Manufacturing networks and supply chains: an operations strategy perspective. Omega, v. 3, n. 1, p. 29-39, 2003.

SHAH, R.; WARD, P. T. Lean manufacturing: context, practice bundles, and performance. Journal of Operations Management, v.21, n.2, p. 129-149, 2003.

SHINGO, S. Study of Toyota production systems. Tokio: Japan Management Association, 1981.

SILVER, E. A.; PYKE, D. F.; PETERSON, R. Inventory management and production planning and scheduling, $3^{\text {rd }}$ Ed. New York: John Wiley \& Sons, 1998.

SKINNER, W. Manufacturing: the formidable competitive weapon. New York: Wiley, 1985.

SLACK, N.; JOHNSTON, R.; CHAMBERS, S. Administração da produção. 2. ed. São Paulo: Atlas, 2002.

SOMAN, C. A.; VAN DONK, D. P.; GAALMAN, G. Combined make-to-order and make-to-stock in a food production system. International Journal of Production Economics, v. 90 , n. 2, p. 223-235, 2004.

SOUZA, R.; VOSS, C. A. Operational implications of manufacturing outsourcing for subcontractor plants. International Journal of Operations \& Production Management, v, 27, n. 9, p. 974-997, 2007.

SPEARMAN, M., WOODRUFF, D.; HOPP, W. CONWIP: a pull alternative to kanban. International Journal of Production Research, v.28, n. 5, 879-894, 1990.

STEVENSON, M Refining a Workload Control (WLC) concept: a case study. International Journal of Production Research, v. 44, n.4, p. 767-790, Mar. 2006.

; HENDRY, L.C.; KINGSMAN, B.G. A review of production planning and control: the applicability of concepts to the make-to-order industry. International Journal of Production Research, v. 43, n.5, p. 869-898, Mar. 2005.

Aggregate load-oriented workload control: a review and a reclassification of a key approach. International Journal of Production Economics, v.104, n.2, p.676-693, Dec. 2006.

SURI, R. QRM and POLCA: A winning combination for manufacturing enterprises in the $21^{\text {st }}$ century. Technical Report, Center for Quick Response Manufacturing, May 2003. 
SUZAKI, K. The new manufacturing challenge: techniques for continuous improvement. New York: Free Press, 1987.

SWINK, M; NARASIMHAN, R.; KIM, S. W. Manuraturing practices and strategy integration: effects on cost efficiency, flexibility, and market-based performance. Decision Sciences, v. 36, n, 3, p. 427-457, 2005.

TAN, K. C.; KANNAN, V. R.; NARASIMHAN, R. The impact of operations capability on firm performance. International Journal of Production Research, v.45, n.21, p. 5135-5156, 2006.

TAN, K, H.; PLATTS, K. The connectance model revisited: a tool for manufacturing objective deployment. Journal of Manufacturing Technology Management, v. 15, n. 2, p. 131-143, 2004

TANGEN, S. Analyzing the requirements of performance measurement systems. Measuring Business Excellence, v. 9, n. 4, p. 46-54, 2005.

VOLLMANN, T.; BERRY, W.; WHYBARK, D.; JACOBS, F.R. Manufacturing planning and control systems. 4. ed. New York: McGraw-Hill/Irwin, 2005.

VOKURKA, R. J.; LUMMUS, R. R.; KRUMWIEDE, D. Improving manufacturing flexibility: the enduring value of JIT and TQM. S. A. M. Advanced Management Journal, v. 72, n. 1, p. 14-21, 2007.

VOSS, C. A. Paradigms of manufacturing strategy re-visited. International Journal of Operations Management, v. 25, n.12, p.1223-1227, 2005.

WHITE, R. E.; PEARSON, J. N.; WILSON, J. R. JIT manufacturing: a survey of implementations in small and large U.S. manufacturers. Management Science, v.45, n.1, p.1-15, Jan 1999.

WARD, P. T.; MCCREERY, J. K.; ANAND, G. Business strategies and manufacturing decisions. International Journal of Operations \& Production Management, v. 27, n, 9, p. 951-973, 2007.

WIKNER, J.; RUDBERG, M. Integrating production and engineering perspectives on the customer order decoupling point. International Journal of Operations \& Production Management, v. 25, n. 7, p. 623-641, 2005.

WOMACK, J. P. Value stream mapping. Manufacturing Engineering, v.136, n.5, p. 145-156, 2006. 